\title{
Using Economic Factors to Forecast the USD/VND Exchange Rate: Case in Vietnam
}

\author{
Nguyen Van DINH ${ }^{*}$, Bui Tran Huy KHANH ${ }^{2}$, Nguyen Thi Thuy LINH ${ }^{3}$ \\ ${ }^{1}$ Vietnam National University, Hanoi - International School \\ ${ }^{2}$ Vietnam National University, Hanoi - University of Economics and Business \\ ${ }^{3}$ Vietnam National University, Hanoi - Vietnam Japan University \\ *Corresponding author: dinhnv@vnuis.edu.vn
}

\begin{abstract}
For a long time, forecasting currency exchange rate has been playing an important role for guiding the progress of the economy. There were many theories and fundamental methods to forecast exchange rate being suggested and used. Each of them has their own advantages and limited points in determining the factors that might influence the fluctuations of the currency exchange rate.
\end{abstract}

\section{Research purpose:}

To review the fundamental methods to forecast exchange rate has been used and suggest a method for determining factors affecting the USD/VND exchange rate

\section{Research motivation:}

The exchange rate of USD/VND is one of the most important monetary policy instruments of Vietnam government. A significant fact is that the international exchange in Vietnam mainly uses the US dollar. Even though the author cannot find a trusted statistical data to show this, but it can be estimated that more than 80 percent of international trade transactions in Vietnam are in US dollar (Hoang Dinh Minh, 2014). It explains why SBV using USD/VND exchange rate as center exchange rate to control the Forex system. Since Vietnam joining the WTO in 2007, the market economy has been widening thanks to more international trade, which in turn attracts more attention to the USD/VND exchange rate. Despite its important role in Vietnam economy, there has not been many economic theories and development policies based on the fluctuation of the USD/VND exchange rate such as how exchange rate reflecting inflation, trade balance, export and import,... and their consequences on the overall market performance in Vietnam.

\section{Research design, approach and method:}

To test the hypothesis of "Could the gaps of inflation and interest rate between the United States and Vietnam economy explain USD/VND exchange rate better than inflation and interest rate themselves", the study is going to compare two groups of variables. Group 1: The difference of inflation between Vietnam and U.S.A; The difference of interest between Vietnam and U.S.A; GDP of Vietnam; Balance of payment (current account) of Vietnam; Reserves of Vietnam; USD/VND exchange rate. And Group 2: Inflation of Vietnam; Interest of Vietnam; GDP of Vietnam; Balance of payment (current account) of Vietnam; Reserves of Vietnam; USD/VND exchange rate

The raw data were collected quarterly from 2005Q1 to 2017Q4, with a total of 52 observations. Then by using Vector Error Correction Model (VECM), the paper aims at finding better ways to assess the factors influence the USD/VND exchange rate. Moreover, through the analysis of Impulse Response Function, Variance Decomposition, Residual Unit Root Test, Granger Causality... the model is check to see whether it fits or not.

\section{Main findings:}

Results of the research point out that the main endogenous factors (excluding exchange rate) affecting exchange rate within chosen variables is GDP, however, its role is significant only in the long-run. Whereas, in the short-run, only Interest rate factor does Granger-cause Exchange rate. And surprisingly, a shock of reverses only helps to restrain Exchange rate volatility in the short-run, but cannot help in long run, especially in the later periods of the study. This response may imply that in the long-run, Reserves should not be used as an instrument to restrain Exchange rate in Vietnam in the long-term. Additionally, other variables have long-run affecting to exchange rate in a different level of significance.

\section{Practical/managerial implications:}

The main positive results of the paper aligns with some proven studies that the factors were chosen has long-run or 
short-run affecting to exchange rate. Furthermore, the paper finds that: GDP affecting Exchange rate in long-run, Interest rate influence exchange and have a positive effect in the long-run. This study will provide some implications for government in exchange rate intervention policy, as well as for other organizations such as import-export firms and commercial banks. Indeed, they can take advantages of the model to develop a tool to minimize the risk of exchange rate fluctuation.

Keywords: USD/VND exchange rate, factors affecting, VECM, fundamental factors, factors affecting, Vietnamese economic factor

\section{INTRODUCTION}

The exchange rate of USD/VND is one of the most important monetary policy instruments of Vietnam government. There are many studies on the topic related to exchange rate regime, for example, exchange rate affecting inflation, trade balance, export, import firms... However, it has been found that a few of studies in the direction of the factors influencing USD/VND exchange rate.

A significant fact that the international exchange in Vietnam mainly uses the US dollar, the authors cannot find a trusted statistical data, but it can be estimated that more than 80 percent of international trade transactions in Vietnam are using US dollar (Hoang Dinh Minh, 2014), it explains why SBV using USD/VND exchange rate as center exchange rate to control the forex system.

Since Vietnam joining the WTO in 2007, opened for widening the market economy, and the USD/VND exchange rate has received much attention. Especially in 2016, when SBV had a positive move to announce that exchange rate will be listed base on a basket of currencies and market demand via the Decision 2730/QĐ-NHNN dated Dec 31, 2015, for example, the USD/VND central exchange rate will be listed daily and be allowed moving around $+/-3 \%$, it means SBV has been using managed floating exchange rate regime based on market supply and demand.

Despite its important role in the Vietnamese economy, there has not been many economic theories and development policies based on the fluctuation of the USD/VND exchange rate such as how exchange rate affecting inflation, trade balance, exportation and importation,... and their consequences on the overall market performance. The knowledge on what factors influence the USD/VND exchange rate and how they do that is very few and limited for Vietnamese to effectively. This could be due to the fact that Vietnam used to have a long episode of a fixed exchange rate regime (1992-98), which means the exchange rate is controlled by the administrative command from SBV in the effort to regain the stability of the Vietnamese dong after currency crisis in 1990-91 (Mai Thu Hien, 2007). Therefore, it has been very few information and arguments over the object since the behavior of the administrative command is hard to be quantified. However, as Vietnam government shifted their policies to managed floating exchange rate regime in 1999 as well as Vietnam joining the WTO in 2007, expanding the market economy, the USD/VND exchanged rate has received more and more attention from both the financial entities as well as scholars. Especially in 2016, when SBV announced that the currency exchange rate will be listed according to basket of currencies and market demand (via Decision 2730/QĐ-NHNN dated Dec 31, 2015) stated that the USD/VND central exchange rate will be listed daily and will be based on multiple market and interbank data.

Therefore, the research topic on "factors affecting the exchange rate of USD/VND" should be more considered. From various kind of foreign studies, it can be easily listed some factors that affect the exchange rate: exchange rate itself, balance of payments, trade balance, inflation, consumer price index, money supply (M2), interest rates, foreign exchange reserves, government expenditure, speculation, monetary policy, seasonal factors ... However, in the scale of the dissertation, the authors wants to focus primarily on two questions: What factors mainly affect to USD/VND exchange rate? Is this impact in the short term or long term?

\section{LITERATURE REVIEW AND THEORETICAL FRAMEWORK}

\subsection{Literature review}

\subsubsection{Brief of foreign studies:}

Exchange rate takes an endless discussion in the academic world, from many directions: Exchange rate affecting to what? Factors affecting exchange rate? How far the effect? And one of the most controversial questions is how to forecast exchange rate? In general, there are six approaches in forecasting exchange rate: (1) The purchasing power parity (PPP) (2) PPP adjusted for the Balassa-Samuelson and Penn effects (3) the macroeconomic balance framework (4) Assessments of the Competitiveness of the tradable goods sector (5) Assessments based on estimated exchange rate equations (6) Assessment based on general equilibrium models (Peter Isard, 2007). But none of those approaches can be useful for all types of the economy because the exchange rate depends on a number of factors, some of them even could not be quantified. Therefore, some studies go to discuss the relationship between exchange rates and economic variables rather than focus on the prediction of exchange rate movement. Which direction be chosen depends on what purpose of the authors.

The initial study examined the influence of Capital inflows to real exchange rate appreciation in 10 
countries of Latin America showing that the capital flows together with contributing in the development of this region, but also relevant to serious issues, i.e.: increasing real exchange rate volatility, which may harm the export sector; creating misallocation of resources when not properly distributed; or leading to an internal financial crisis. The paper also showed a strong evidence of a negative shock to U.S rates would create a remarkable official reserves and real exchange rate consideration in the tested countries. Then the paper gave a comprehensive solution in policy perspective, such as: adding tax on capital imports; trade policy; fiscal tightening; central bank sterilized and on-sterilized intervention of capital inflows; or a rise in marginal reserve requirements on bank deposits and more regulated bank investments in equity and real estate markets (C. Reihart and G. Calvo and L. Leiderman, 1992), proved the important role of exchange rate in emerging countries.

By another approach Jorge C.K. and Karl H. (2004) in investigated the structural factors affecting exchange rate volatility in a cross-section study by a qualitative survey collected from IMF. This is the first time using that method to find that decentralizing dealer markets, putting the regulations on the use of domestic currency to non-residents, accepting and limiting banks positions in currency exchange services can help exchange rate volatility more stable. A message to government and nations that want to stabilize the exchange rate volatility should be reached some macroeconomic conditions and fitted exchange rate regime.

YL Ng, WM Har, GM Tan (2008) tried to determine the effect between the real exchange rate and trade balance in Malaysia, the data period from 1955-2006 of real exchange rate and trade balance in Malaysia and test with Marshall-Lerner and J-curve effect exist, using VECM model and focused on analyzing the impulse response and found the long run relationship exists between those two factors, and other important factors such as domestic income.

For another study, S. Parveen, A.Q.Khan, M.Ismail (2012), examined the factors contributing the nominal exchange rate vitality in Pakistan from the period 1975-2010 including inflation, GDP, imports, and exports by using a simple linear Regression model with ordinary least method. The paper found that the inflation is the main factor affecting exchange rate in Pakistan.

According to M. Iyoboyi \& O. Muftau (2014) studied the impact of exchange rate depreciation on Nigeria balance of payments. The analysis is based on the multivariate vector correction framework (VECM) and annual data from 1961-2012 and provides a policy implication in enhancing growth in the real sector that can influence for a positive Balance of Payment. A major finding of the study was that the movement of exchange rates in Nigeria was not statistically affected by changes in the variables determined.
Recently, a study of the exchange rate in emerging market - N.Q. My (2016) built a regression equation (ANOVA model) to test the impact of macroeconomic factors on the exchange rates of United States of America to four big emerging countries: China, India, Brazil, and Mexico. The factors are: exchange rate, inflation, short-term and long-term interest rate, trade balance, import and export, public debt rate to GDP, international reserves, foreign direct investment for a financial transaction and for income. The main finding that $98 \%$ of total variances in USD/CNY can be explained by the macroeconomic factors, while this number is $86.2 \%$ in the pair of USD and INR currencies, only $59.3 \%$ in USD/BRL, and $87.6 \%$ with USD/MXN.

From the above studies, implying a model can explain exchange rate from macroeconomic factors, and it is various from country to country. As an emerging market, Vietnam has many differences with the study has figured out in the developed market. In the next section, we will briefly talk about studies related to exchange rate in Vietnam

\subsubsection{Studies in Vietnam:}

In Vietnam, due to the exchange rate is used as a monetary policy instrument of the government, lead to many studies discuss on exchange rate USD/VND policy impacts on other variables, for example, inflation, trade balance, GDP... The wide-known paper in Vietnam went to investigate the effect of Exchange rate pass-through (ERPT) to the inflation (Vo Van Minh, 2009), due to Vietnam had suffered from the period of hyperinflation at the end of $1980 \mathrm{~s}$, and the global financial crisis in 2007-2008 raised the fear of another hyperinflation coming to Vietnam. The exchange rate change will inevitably affect import prices and import prices for production. ERPT here is defined as a complete translation of exchange rate change to import price, there commonly has a partial ERPT which does not fully transmit the full exchange rate change to the import price change and a zero ERPT means that exchange rate change does not affect the import price. The exchange rate change will definitely affect the price of imports and the price of imported inputs for production. The study pointed out that exchange rate control is not an effective monetary policy to curb inflation. Meanwhile, oil price shocks or market response to government regulatory policies affect inflation more than the exchange rate, then gives the idea of stopping exchange rate intervention policy. This study paves the way for subsequent studies on exchange rates, however, in the direction of how the exchange rate policy will affect the variables of the economy.

Another research of N.K Nam, T.N Hao, N.T.H Nga (2014) determined the impact of the exchange rate de on Vietnam's inflation, using the purchasing power parity approach under Hooper and Mann (1989), Johansen cointegration and ECM for the quarterly data from 1992Q1 to 2012Q14, and found that in the short run transmission of foreign exchange rates to inflation is not 
complete, if the exchange rate increases by $1 \%$, the inflation rate is expected to increase by $0.35 \%$ and in the long term, the transmission of foreign exchange rates to inflation is complete. and at a very high level, if the exchange rate increased to $1 \%$, the inflation rate increased by $1.3 \%$.

In studying the effects of exchange rate volatility on Vietnamese inflation from 2002 to 2014, the authors divided periods into 2 phrases: from 2002-2006 and from 2007-2014 (T.V. Hung, 2015). And empirical evidence shows that the effects of the exchange rate period from 2007 to 2014 is much stronger to inflation. This suggests that the year of 2007 when Vietnam joined the WTO as a milestone, once again played an important role in promoting further exchange rate research.

In assessing the impact of real exchange rates and other factors on the trade balance in Vietnam D.T.H. Cuc (2016) found the relationship of macro factors as the bilateral real exchange rate, gross domestic income, US trading partner's income and trade balance from data was collected from 1980 to 2015 . The results show that there is a long-term relationship between the real exchange rate and the trade balance in Vietnam. There is no evidence, however, of the existence of short-term J-curve effects. This proves that after the devaluation of the trade balance will be a short-term deficit but not likely to improve in the long term. In the longer term, the trade balance tends to improve after devaluation. The impact of the bilateral real exchange rate on the trade balance in the long term is not that great, so it is recommended that when adjusting the exchange rate policy to improve the trade balance, other macroeconomic policies should be included: public debt, interest rate, inflation, ... Then propose a solution to target balance trade of Vietnam. The variables in the model include trade, real bilateral exchange rates, gross domestic product, gross margins.

On the other hand, V.P. Thuy (2017) examined the relationship between the exchange rate and the trade balance from 2005 to 2015 . The paper indicated that the exchange rate has a negative impact on the trade balance and is significant at $1 \%$. The implication is that when the currency devalues at $1 \%$ (increasing the exchange rate by $1 \%$ ), the trade deficit will increase by $0.0777 \%$.

Recently, to perform the commitment when joining the WTO and access to other developed markets, Vietnam started to open more the economy around the year 2007 and gradually loosening its control to the market. The year 2016 was a remarkable year when witnessed as a huge effort of the SBV to change the regulation of the exchange rate by the Decision No.2730/QĐ-NHNN dated $12 / 31 / 2015$ i.e. the center rate is listed daily change with a wider fluctuation range of $+/-3 \%$, allowing the exchange rate movement more flexibly. This event opened a road in studying topic "factors affecting the exchange rate" in consulting to the government in monetary policy.
One example is the study in "Using the VAR model to analysis factor affecting the exchange rate of USD/VND and forecasting the USD/VND exchange rate (H.T.N. Lan, 2016). This paper has shown the effort of the authors and basic factors affecting the exchange rate of Vietnam in the period 2005-2015. Based on the variables of interest rate difference between Vietnam and the United States, the inflation differences between Vietnam and the United States of America, GDP, trade balance, foreign exchange reserves and exchange rate itself to calculate the equation for factors influence the exchange rate. The pick-up variables of the study are similar with the well-known six factors affecting exchange rate by Bergen J.V (2018) i.e.: Differential in Inflation, Differential in Interest Rates, Current-Account Deficits, Public Debt, Terms of Trade, Political Stability and Economic Performance. And the main finding of the paper is trade balance and reserves take the largest proportion to exchange rate in the long-run horizon. However, the ratio of trade balance is growing by time, whereas, the ratio of reserves is stable by time.

\subsection{Theoretical Framework (hypothesis development)}

\subsubsection{Brief of Vietnam forex market history}

Before 1991: Vietnam had no forex market at that time. The international transaction mostly with the USSR (Union of Soviet Socialist Republics) or China. The exchange rate at that time was fixed by governments depended on what kind of transaction with no market-driven factors.

After 1991: in 1991, Vietnam started establishing a foreign exchange transaction center the year marked with the collapse of the Soviet Union and the emergence of economic requirement. But the center could not carry all the demand of the market, and soon was replaced by the Interbank market in 1994, which was formed as initial forex market, included: commercial banks, investment banks, financial institutions, SBV and import-export firms.

Since then, Vietnam had witnessed the Asian Financial Crisis in 1997 and chosen the exchange rate sterilized intervention policy since 1999 via Regulation 86/ND-CP1999 dated August 30, 1999 - under the requirement of government in creating a signal channel to the market as well as stimulated the export transaction.

The Financial Crisis 2007-2008 with its global scale effect is a pressure to Vietnam, too. With the commitment of more opening the market after the WTO. One of the hot topic at that time in Vietnam is the market strong enough to use no exchange rate intervention? And the answer was definitely "no."

After several years struggling in control the exchange rate market, despite the government effort, the free market still had sharply fluctuated. The action of SBV via Decision 2730/QĐ-NHNN has received good feedback from the market (P. Linh, 2016) and opened new phrase 
in the forex market as a loosening policy signal of the government.

\subsubsection{Variables Selection}

According to suggestion of previous papers, and in the scale of the thesis with limited time and data access, the authors intend to use some variables such as: Differential in inflation between Vietnam and U.S.A, differential in interest rates between Vietnam and U.S.A, Current account of Balance of Payment (hereafter called Balance of Payment) of Vietnam, GDP growth rate of Vietnam, and Vietnam reserves. But in fact, while about 80 percent of amount of international payments between Vietnam and the world are in US dollar (Hoang Dinh Minh, 2014), the trading between Vietnam and USA took only $23.2 \%$ of export and $5.7 \%$ for import activities in Vietnam according to Vietnam General Department of Customs in 2019. Hence, the authors began to wonder: Could the differentials of inflation and interest rate between the United States and Vietnam economy explain USD/VND exchange rate better than inflation and interest rate themselves?

From the raw data, the authors leans on the assumption that Vietnam's inflation and interest rates themselves reflect the all the factors affecting them (including external factors from the United States and other countries have transactions with Vietnam), so we can get better explain to the differentials between Vietnam and U.S.A.

Regarding the data, the research will focus on data from the year 2005, because of from this year on, Vietnam had to prepare to open market more to meet some initial requirement of the WTO in 2007, hence, the macroeconomic data from 2005 could be more meaningful with market demand influences.

To test the above hypothesis, the study is going to compare two group of variables below:

Table 1. The Group of Variables:

\begin{tabular}{|c|c|c|}
\hline No. & Group 1 & Group 2 \\
\hline 1 & $\begin{array}{l}\text { The difference of } \\
\text { inflation between } \\
\text { Vietnam and U.S.A }\end{array}$ & Inflation of Vietnam \\
\hline 2 & $\begin{array}{l}\text { The difference of } \\
\text { interest between } \\
\text { Vietnam and U.S.A }\end{array}$ & Interest of Vietnam \\
\hline 3 & GDP of Vietnam & GDP of Vietnam \\
\hline 4 & $\begin{array}{l}\text { Balance of payment } \\
\text { (current account) of } \\
\text { Vietnam }\end{array}$ & $\begin{array}{l}\text { Balance of payment } \\
\text { (current account) of } \\
\text { Vietnam }\end{array}$ \\
\hline 5 & Reserves of Vietnam & Reserves of Vietnam \\
\hline 6 & $\begin{array}{l}\text { USD/VND exchange } \\
\text { rate }\end{array}$ & $\begin{array}{l}\text { USD/VND exchange } \\
\text { rate }\end{array}$ \\
\hline
\end{tabular}

(Source: Author, 2021)
Where:

(1) GDP: Gross Domestic Products Growth rate. The authors collecting this data from various sources, mainly from GSO, and synthesized from other online paper.

(2) Inflation: the authors uses the raw CPI to calculate the inflation (because Vietnam is using the core inflation that eliminates the seasonal factor). With the listed exchange rate using in this study, the authors wants to use the initial inflation to understand the movement of the exchange rate.

(3) Interest rate: in the thesis, authors using monetary policy interest rate, that provided by IMF.

(4) Reserves: or Foreign Exchange Reserves are reserve assets held by a central bank in foreign currencies, used to back liabilities on their own issued currency as well as to influence monetary policy ${ }^{1}$. In the thesis, the reserves of Vietnam is the total reserves excluding Gold.

(5) Balance of payment ${ }^{2}$ : in IMF definition, the Balance of Payment identity can be written as follows: current account+financial account+capital account+balancing item $=0$. The IMF uses the term current account with the same meaning as that used by other organizations, although it has its own names for its three leading sub-divisions, which are: The goods and services account; The primary income account (factor income such as from loans and investments); The secondary income account (transfer payments). The thesis only uses the Current account data of BOP.

(6) USD/VND Exchange rate: Data in the thesis used the listed exchange rate between US dollar and Vietnam Dong which announced by SBV. Depends on which period, the USD/VND exchange rate can be called as the central exchange rate or the average interbank exchange rate.

\section{METHODOLOGY}

\subsection{Sources of data and Description of Variables}

The quarterly data from 2005Q1 to 2017Q4 was used to test the paper. The data was collected mostly from IFS: nominal exchange rate of USD to VND, CPI, Interest rate (for monetary policy), Balance of payment (current account only), Reserves; GDP growth rate from GSO, and synthesized from other sources for the lack of some data, i.e.: the interest rate of 2017Q4 from tradingeconomics.com, balance of payment in 2017Q3 and Q4.

The authors calculated the Inflation from CPI collected

\footnotetext{
1 According to Investopedia,

https://www.investopedia.com/terms/f/foreign-exchange-reserves.asp

2 Source: Wikipedia,

https://en.wikipedia.org/wiki/Balance of payments
} 
from IFS to avoid collecting the core inflation ${ }^{3}$ data or the different way of calculating inflation between Vietnam and U.S in some periods.

The Interest rate data was chosen from the monetary policy interest rate as a signal interest rate for the market, it is usually higher than deposit rate, and lower than interest rate for a loan

The Balance of payment - current account is used because of it is contributed by 3 components: the overall trade balance; the factor income such as from loans and investments); and the transfer payments, which can represent better than trade balance (as another study in Vietnam has been used), because it includes not only good and services transaction but the short income and payments, which also using the exchange rate.

GDP growth rate definition is very clear and doesn't have any notice, then I will not go into the detail how to pick up this data.

While Reserves was sorted from the international liquidity data of IMF which is Total Reserves excluding Gold.

Finally, the paper uses stated Exchange rate between USD and VND at the end of a quarter, in other words, it could be called "the USD/VND average interbank exchange rate" or "USD/VND central exchange rate" which depends on period and administrative command from SBV, and the data was taken from IFS.

Table 2. Notation of variables

\begin{tabular}{|l|l|l|l|l|}
\hline Variables & $\begin{array}{l}\text { Abbrev } \\
\text { iation }\end{array}$ & Note & Unit & $\begin{array}{l}\text { Data } \\
\text { source }\end{array}$ \\
\hline $\begin{array}{l}\text { Exchange } \\
\text { rate } \\
\text { USD/VN } \\
\text { D }\end{array}$ & EX & $\begin{array}{l}\text { The listed } \\
\text { exchange } \\
\text { rate at the } \\
\text { end of the } \\
\text { quarter }\end{array}$ & $\begin{array}{l}\text { USD/V } \\
\text { ND }\end{array}$ & IMF \\
$\begin{array}{l}\text { Logarithm } \\
\text { of the } \\
\text { Exchange } \\
\text { rate }\end{array}$ & LEX & & & \\
\hline $\begin{array}{l}\text { Inflation } \\
\text { IFN }\end{array}$ & $\begin{array}{l}\text { Calculate } \\
\text { from CPI }\end{array}$ & $\%$ & IMF \\
\hline $\begin{array}{l}\text { The } \\
\text { Differenti } \\
\text { al } \\
\text { between }\end{array}$ & IFD & & & \\
\hline
\end{tabular}

${ }^{3}$ Core inflation is an inflation measure which excludes transitory or temporary price volatility as in the case of some commodities such as food items, energy products etc. It reflects the inflation trend in an economy (The Economic Times). Vietnam is using core inflation calculated by CPI that excluded the food, energy, healthcare services and education services (CPIxFEAHE) (GSO). Meanwhile, U.S is using core inflation which calculates from CPI excludes volatile items such as food and energy (tradingeconomics.com).

${ }^{4}$ Using logarithm of Exchange rate to reduce the dispersion, as well as limit some abnormalities, which helps the running data more stable.

\begin{tabular}{|c|c|c|c|c|}
\hline $\begin{array}{l}\text { Vietnam } \\
\text { and U.S } \\
\text { inflation }\end{array}$ & & & & \\
\hline $\begin{array}{l}\text { Interest } \\
\text { rate }\end{array}$ & IT & $\begin{array}{l}\text { The } \\
\text { monetary } \\
\text { policy } \\
\text { interest } \\
\text { rate }\end{array}$ & & \\
\hline $\begin{array}{l}\text { The } \\
\text { differentia } \\
1 \text { between } \\
\text { Vietnam } \\
\text { and USD } \\
\text { interest } \\
\text { rate }\end{array}$ & ITD & & $\%$ & IMF \\
\hline $\begin{array}{l}\text { Gross } \\
\text { Domestic } \\
\text { Products } \\
\text { growth } \\
\text { rate }\end{array}$ & GDP & & $\%$ & $\begin{array}{l}\text { GSO, } \\
\text { Vietstoc } \\
\text { kFinance } \\
\text { Cafef.vn }\end{array}$ \\
\hline $\begin{array}{l}\text { The } \\
\text { Balance } \\
\text { of } \\
\text { Payment-c } \\
\text { urrent } \\
\text { account }\end{array}$ & BOP & & $\begin{array}{l}\text { Billion } \\
\text { USD }\end{array}$ & IMF \\
\hline 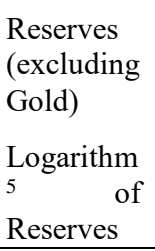 & $\begin{array}{l}\mathrm{R} \\
\mathrm{LR}\end{array}$ & & $\begin{array}{l}\text { Billion } \\
\text { USD }\end{array}$ & IMF \\
\hline
\end{tabular}

(Source: Author, 2021)

The data were collected from Q1/2005 to Q4/2017 with a total of 52 observations. Data sources and notice are mentioned on the Table 2. above.

\subsection{General Model}

Equation of Group 1:

- $\quad$ LEX $=\beta_{0}+\sum_{\mathrm{i}=1}^{\mathrm{k}} \beta_{1 \mathrm{t}-\mathrm{i}} \mathrm{LEX}_{\mathrm{t}-\mathrm{i}}+$ $\sum_{\mathrm{i}=1}^{\mathrm{k}} \beta_{2 \mathrm{t}-\mathrm{i}} \mathrm{IFD}_{\mathrm{t}-\mathrm{i}}+\sum_{\mathrm{i}=1}^{\mathrm{k}} \beta_{3 \mathrm{t}-\mathrm{i}} \mathrm{ITD}_{\mathrm{t}-\mathrm{i}}+$ $\sum_{\mathrm{i}=1}^{\mathrm{k}} \beta_{4 \mathrm{t}-\mathrm{i}} \mathrm{GDP}_{\mathrm{t}-\mathrm{i}}+\sum_{\mathrm{i}=1}^{\mathrm{k}} \beta_{5 \mathrm{t}-\mathrm{i}} \mathrm{BOP}_{\mathrm{t}-\mathrm{i}}+$ $\sum_{\mathrm{i}=1}^{\mathrm{k}} \beta_{6 \mathrm{t}-\mathrm{i}} \mathrm{LR}_{\mathrm{t}-\mathrm{i}}+\varepsilon_{\mathrm{t}}$

Equation of Group 2:

- $\quad \operatorname{LEX}=\beta_{0}+\sum_{\mathrm{i}=1}^{\mathrm{k}} \beta_{1 \mathrm{t}-\mathrm{i}} \operatorname{LEX}_{\mathrm{t}-\mathrm{i}}+$ $\sum_{\mathrm{i}=1}^{\mathrm{k}} \beta_{2 \mathrm{t}-\mathrm{i}} \mathrm{IFN}_{\mathrm{t}-\mathrm{i}}+\sum_{\mathrm{i}=1}^{\mathrm{k}} \beta_{3 \mathrm{t}-\mathrm{i}} \mathrm{IT}_{\mathrm{t}-\mathrm{i}}+$ $\sum_{\mathrm{i}=1}^{\mathrm{k}} \beta_{4 \mathrm{t}-\mathrm{i}} \mathrm{GDP}_{\mathrm{t}-\mathrm{i}}+\sum_{\mathrm{i}=1}^{\mathrm{k}} \beta_{5 \mathrm{t}-\mathrm{i}} \mathrm{BOP}_{\mathrm{t}-\mathrm{i}}+$ $\sum_{\mathrm{i}=1}^{\mathrm{k}} \beta_{6 \mathrm{t}-\mathrm{i}} \mathrm{LR}_{\mathrm{t}-\mathrm{i}}+\varepsilon_{\mathrm{t}}$

Where:

\section{- $\quad \beta$ : are the coefficients to estimate}

\footnotetext{
${ }^{5}$ Using logarithm of Reserves to reduce the dispersion, as well as limit some abnormalities, which helps the running data more stable.
} 
- $\varepsilon:$ is a random error/disturbance term

- $\quad t$ : time, $k$ : lag length

In the next section, the authors will list the step of using Vector Error Correction Model in the paper.

\subsection{Model Estimate Procedure}

Steps to run the model:

Step 1 - Unit root test:

In time series model, Unit root test is one of the important first step to check the stationarity of variables. A series data is stationary means the statistical parameters of this series (such as mean, variance, deviation, autocorrelation, etc.) are all constant over time. In case the variables are non-stationary in ntime series, for example, the dependent variable $\mathrm{Y}$ and independent variable $\mathrm{Y}$ are non-stationary, the model of the $\mathrm{Y}$ and $\mathrm{X}$ relationship will be a lead to generate a spurious regression simple Ordinary Least Square equation as:

$\mathrm{Y}_{\mathrm{t}}=\alpha+\beta \mathrm{X}_{\mathrm{t}}+\varepsilon_{\mathrm{t}}$

The equation of unit root test uses for a variable $\mathrm{X}$ in VECM is as below:

$\mathrm{X}_{\mathrm{t}}=\alpha_{0}+\alpha_{1} \mathrm{X}_{\mathrm{t}-1}+\varepsilon_{\mathrm{t}}$

Where: $\alpha_{0}, \alpha_{1}$ and are parameters need to be estimated, and $\varepsilon_{t}$ is the disturbance term which is assumed that be distributed normally. If $\varepsilon_{\mathrm{t}}$ has all conditions: Expectation $\mathrm{E}\left(\varepsilon_{\mathrm{t}}\right)=0$; Variance $\delta\left(\varepsilon_{\mathrm{t}}\right)=0$ and Covariance $\gamma=0$, then $\varepsilon_{\mathrm{t}}$ is white disturbance, or the disturbance is stationary.

Unit root test based on the Null hypothesis $\left(\mathrm{H}_{0}\right)$ : (Variable) $\mathrm{X}$ has a unit root. If the $\mathrm{P}$-value of the test is smaller than $5 \%$, then the $\mathrm{H}_{0}$ is rejected in favor of alternative hypothesis: Variable X doesn't have unit root or Data series of $\mathrm{X}$ is stationary.

For all series data, if the data is stationary at level, move to the next step; if the data is non-stationary at level, then check the first difference, if not, check to second difference. The first difference of variable $X_{t}$ is the changes from one period to the next. For example:

First difference of $\mathrm{X}$ series is: $\mathrm{I}(1)=\mathrm{D}(\mathrm{X}, 1)=\mathrm{X}_{\mathrm{t}}-\mathrm{X}_{\mathrm{t}-1}$ (5)

Second difference of $\mathrm{X}$ series is $\mathrm{I}(2)=\mathrm{D}(\mathrm{X}, 2)=\mathrm{X}_{\mathrm{t}}-\mathrm{X}_{\mathrm{t}-2}$ (6) and so on.

If the data is stationary at first difference I(1), move to the second step.

Step 2: Optimal Lag Selection: Run VAR model at first to get the optimal lag, using the FPE, AIC or SC criteria to determine which one should be used. One notice that the longer lag is chosen, the less accuracy of the parameter estimates (lowering the degrees of freedom), hence, we should choose the shorter lag despite the fact that a longer lag can improve the $\mathrm{R}^{2}$.

\section{Step 3: Johansen Cointegration Test:}

The Johansen test including two tests which determine the number of conintegration vectors: Maxi-Eigenvalue Test and Trace test. The Maximum Eigenvalue test examines the largest eigenvalue is zero relative to the alternative that the next largest eigenvalue is zero. The test statistics is estimated as the following formula:

$\mathrm{LR}\left(\mathrm{r}_{0}, \mathrm{r}_{0+1}\right)=-\mathrm{T}^{*} \ln \left(1-\lambda_{r 0+1}\right)$

Where:

- $\quad$ LR is Likelihood Ratio test statistic ${ }^{6}$.

- $\quad \lambda$ is the the Maximum Eigenvalue at time i.

- $\quad \mathrm{T}$ is the sample size.

- $\quad \mathrm{n}$ is the number of variables.

- $\quad r$ is the number of cointegration relations in the model.

Trace test is used to examine the null hypothesis of $\mathrm{m}$ cointegrating relations against the alternative of $r$ conintegrating relations, where $\mathrm{n}$ is the number of variables, and $\mathrm{r} \leq \mathrm{n}$. The system calculates by the following formula:

$\mathrm{LR}_{\mathrm{im}}(\mathrm{r} / \mathrm{n})=-\mathrm{T} * \sum_{i=m+1}^{n} \ln \left(1-\lambda_{i}\right)$

In case of the different result between 2 tests, Trace test is usually preferred.

Step 4:

- In case of step 2 gives the result: there is no cointegration relationship, which mean we can use VAR model to examine the relationship between variables in long-run and short-run.

- In case of step 2 gives the result: there is $n$ cointegration relationship $(n \geq 1)$ which means we should use VECM model to explain the relationship between variables in long-run, and Granger causality test for short-run.

Step 5: Choose the optimal group, which have significant $\mathrm{F}$-statistic and adjusted $\mathrm{R}^{2}$ is higher.

Step 6: To test the model fitted or not, we run the residual unit root test and Granger causality to check the causality between variables in the short-run.

Granger causality test is a test between two variables $\mathrm{X}$ and $\mathrm{Y}$, which have a relationship could be composed as the formulars:

$\mathrm{Y}_{\mathrm{t}}=\alpha_{0}+\alpha_{1} \mathrm{Y}_{\mathrm{t}-1}+\ldots+\alpha_{\mathrm{i}} \mathrm{Y}_{\mathrm{t}-\mathrm{I}}+\beta_{1} \mathrm{X}_{\mathrm{t}-1}+\ldots+\beta_{i} \mathrm{X}_{\mathrm{t}-\mathrm{i}}+\mu$

$\mathrm{X}_{\mathrm{t}}=\alpha_{0}+\alpha_{1} \mathrm{X}_{\mathrm{t}-1}+\ldots+\alpha_{\mathrm{i}} \mathrm{Xt}-\mathrm{i}+\beta_{1} \mathrm{Yt}-1+\ldots+\beta_{i} \mathrm{Y}_{\mathrm{t}-\mathrm{i}}+\mu$

Where: $\alpha, \beta$ are the coefficients that need to be estimated, and $\mu$ is here the white noise error (or the disturbance term that is stationary in this test).

In this test, we examine the two null hypotheses: " $\mathrm{X}$

${ }^{6}$ For more detail, read the article: The Johansen Tests for Cointegration, Gerald P. Dwyer (2015). 
does not Granger-cause Y" and "Y does not Granger-cause X."

Step 7: Impulse Response Function and Variance Decomposition Analysis: are to test the response of dependent variable $\mathrm{Y}$ with a shock of independent variable $\mathrm{X}$, and the component effects of each variable in a period.

Step 8: Forecasting (within-sample forecasting).

\section{RESULT AND DISCUSSION}

\subsection{Result}

\subsubsection{Unit root tests}

The unit root tests were introduced by the Johansen (1988) framework, after which the examination of short-run dynamics and long-run causality between exchange rate and other macroeconomic are examined by VECM.

In the first step of the measurement, we use unit root test to with the Null hypothesis that the series data have a unit root, we can see the result in the table below, and $\mathrm{X}$ variable will replace by BOP, IFN, IFD, IT, ITD, GDP, LEX, LR and their first difference (which denote as D) respectively, to run unit root test, and we have the summary result in Table 3:

Table 3: Unit Root Test Result

\begin{tabular}{|c|c|c|c|c|}
\hline No. & $\begin{array}{c}\text { Variabl } \\
\text { es }\end{array}$ & $\begin{array}{c}\text { ADF } \\
\text { Test } \\
\text { P-value }\end{array}$ & Result & Note \\
\hline 1 & $\begin{array}{l}\mathrm{BOP} \\
\mathrm{D}(\mathrm{BOP})\end{array}$ & $\begin{array}{l}0.0819 \\
0.0001\end{array}$ & $\begin{array}{l}\text { Non-stati } \\
\text { onary } \\
\text { Stationary }\end{array}$ & $\begin{array}{l}\text { Lag length: } 1 \\
\text { (fixed) }\end{array}$ \\
\hline 2 & $\begin{array}{l}\text { IFN } \\
\text { D(IFN) }\end{array}$ & $\begin{array}{l}0.1689 \\
0.0038\end{array}$ & $\begin{array}{l}\text { Non-stati } \\
\text { onary } \\
\text { Stationary }\end{array}$ & $\begin{array}{l}\text { Lag length: } 2 \\
\text { (fixed) }\end{array}$ \\
\hline 3 & $\begin{array}{l}\text { IFD } \\
\mathrm{D}(\mathrm{IFD})\end{array}$ & $\begin{array}{l}0.0782 \\
0.0004\end{array}$ & $\begin{array}{l}\text { Non-stati } \\
\text { onary } \\
\text { Stationary }\end{array}$ & Default \\
\hline 4 & $\begin{array}{l}\text { IT } \\
\text { D(IT) }\end{array}$ & $\begin{array}{l}0.1457 \\
0.0001\end{array}$ & $\begin{array}{l}\text { Non-stati } \\
\text { onary } \\
\text { Stationary }\end{array}$ & Default \\
\hline 5 & $\begin{array}{l}\text { ITD } \\
\text { D(ITD) }\end{array}$ & $\begin{array}{l}0.3828 \\
0.0006\end{array}$ & $\begin{array}{l}\text { Non-stati } \\
\text { onary } \\
\text { Stationary }\end{array}$ & Default \\
\hline 6 & $\begin{array}{l}\text { GDP } \\
\text { D(GDP) }\end{array}$ & $\begin{array}{l}0.9713 \\
0.0000\end{array}$ & $\begin{array}{l}\text { Non-stati } \\
\text { onary } \\
\text { Stationary }\end{array}$ & $\begin{array}{l}\text { Trend and } \\
\text { Intercept }\end{array}$ \\
\hline 7 & $\begin{array}{l}\text { LEX } \\
\text { D(LEX) }\end{array}$ & $\begin{array}{l}0.8936 \\
0.0000\end{array}$ & $\begin{array}{l}\text { Non-stati } \\
\text { onary } \\
\text { Stationary }\end{array}$ & Default \\
\hline
\end{tabular}

\begin{tabular}{|l|l|l|l|l|}
\hline 8 & LR & 0.9155 & $\begin{array}{l}\text { Non-stati } \\
\text { onary } \\
\text { D(LR) }\end{array}$ & Default \\
\hline
\end{tabular}

Source: Result from Eview 9.5

From the Table 3, the result suggest that all variables are non-stationary at level but stationary at the first difference. Thus, we move to the second step.

\subsubsection{Optimal Lag selection:}

As the result we have in Figure 9 and 10 for the Lag Length Criteria result, and base on a study said that AIC and FPE should be a better choice for small sample (V.K.-Sen Liew, 2004), then the authors choose lag 4 for both groups is the optimal lag length with minimum estimated AIC and FPE.

\subsubsection{Johansen Cointegration Test}

From the result of step 1, we should check the co-integration of those vectors in time series data. The authors used the Johansen and Juselius (1990) with the significance of $5 \%$ to test the null hypothesis: There doesn't exist " $n$ " cointegration relationship(s). Base on the Trace-statistic and Max-Eigen Statistic, we can reject the Null hypothesis. We have:

\section{Group 1:}

From the result of Johansen Cointegration Test in Figure 11, the Trace test indicates 4 cointegration eqn(s) at the 5 percent level. However, Max-Eigenvalue test indicates 2 cointegration eqn(s) at the 5 percent level. The authors chooses the Trace test result to apply for this thesis. In the other words, there are 4 cointegration equations existed in group 1 variables.

\section{Group 2:}

In Group 2, based on the result shows on Figure 12, the Trace test indicates 4 co-integration equations at the 5 percent level, however, Max-Eigenvalue test indicates 5 co-integration equations at the 5 percent level. The authors chooses the Trace test result to apply in this thesis, or there are 4 co-integration equations existed in group 2 variables.

As the result, we can both use VECM in two groups to test the long-run relationships between variables and estimate the models.

\subsubsection{Vector Error Correction Model Estimates}

As the result from the step 2 and 3, we can both use VECM in two groups to test the long-run relationships between variables and estimate the models with: lag length is 4 and 4 cointegration relationships between variables.

Then, the equation to run the model should be in the first difference: 
Equation of Group 1:

- $\quad \operatorname{DLEX}=\beta_{0}+\sum_{\mathrm{i}=1}^{\mathrm{k}} \beta_{1 \mathrm{t}-\mathrm{i}} \mathrm{DLEX}_{\mathrm{t}-\mathrm{i}}+$

$\sum_{\mathrm{i}=1}^{\mathrm{k}} \beta_{2 \mathrm{t}-\mathrm{i}}$ DIFD $_{\mathrm{t}-\mathrm{i}}+\sum_{\mathrm{i}=1}^{\mathrm{k}} \beta_{3 \mathrm{t}-\mathrm{i}}$ DITD $_{\mathrm{t}-\mathrm{i}}+$ $\sum_{\mathrm{i}=1}^{\mathrm{k}} \beta_{4 \mathrm{t}-\mathrm{i}} \mathrm{DGDP}_{\mathrm{t}-\mathrm{i}}+\sum_{\mathrm{i}=1}^{\mathrm{k}} \beta_{5 \mathrm{t}-\mathrm{i}} \mathrm{DBOP}_{\mathrm{t}-\mathrm{i}}+$ $\sum_{\mathrm{i}=1}^{\mathrm{k}} \beta_{6 \mathrm{t}-\mathrm{i}} \mathrm{DLR}_{\mathrm{t}-\mathrm{i}}+\varepsilon_{\mathrm{t}}$

Equation of Group 2:

- $\quad \operatorname{DLEX}=\beta_{0}+\sum_{\mathrm{i}=1}^{\mathrm{k}} \beta_{1 \mathrm{t}-\mathrm{i}} \mathrm{DLEX}_{\mathrm{t}-\mathrm{i}}+$ $\sum_{\mathrm{i}=1}^{\mathrm{k}} \beta_{2 \mathrm{t}-\mathrm{i}} D \mathrm{IFN}_{\mathrm{t}-\mathrm{i}}+\sum_{\mathrm{i}=1}^{\mathrm{k}} \beta_{3 \mathrm{t}-\mathrm{i}} D \mathrm{IT}_{\mathrm{t}-\mathrm{i}}+$ $\sum_{\mathrm{i}=1}^{\mathrm{k}} \beta_{4 \mathrm{t}-\mathrm{i}} \mathrm{DGDP}_{\mathrm{t}-\mathrm{i}}+\sum_{\mathrm{i}=1}^{\mathrm{k}} \beta_{5 \mathrm{t}-\mathrm{i}} \mathrm{DBOP}_{\mathrm{t}-\mathrm{i}}+$ $\sum_{\mathrm{i}=1}^{\mathrm{k}} \beta_{6 \mathrm{t}-\mathrm{i}} \mathrm{DLR}_{\mathrm{t}-\mathrm{i}}+\varepsilon_{\mathrm{t}} \quad$ (12)

we have summary result tables below:

\section{Group 1:}

Table 4: Cointegration Equation of Group 1

\begin{tabular}{|l|l|l|l|l|}
\hline $\begin{array}{l}\text { Cointegrating } \\
\text { Eq: }\end{array}$ & CoinEq1 & CoinEq2 & CoinEq3 & CoinEq4 \\
\hline LEX(-1) & 1.000000 & 0.000000 & 0.000000 & 0.000000 \\
\hline BOP(-1) & 0.000000 & 1.000000 & 0.000000 & 0.000000 \\
\hline GDP(-1) & 0.000000 & 0.000000 & 1.000000 & 0.000000 \\
\hline IFD(-1) & 0.000000 & 0.000000 & 0.000000 & 1.000000 \\
\hline ITD(-1) & -0.006808 & -0.168333 & 0.299087 & -0.007290 \\
\hline & $(0.00202)$ & $(0.08142)$ & $(0.03467)$ & $(0.00187)$ \\
\hline & {$[-3.37527]$} & {$[-2.06747]$} & {$[8.62674]$} & {$[-3.90649]$} \\
\hline LR(-1) & -0.004258 & -0.059765 & 0.011484 & 0.002233 \\
\hline & $(0.00069)$ & $(0.02770)$ & $(0.01180)$ & $(0.00187)$ \\
\hline & {$[-6.20511$} & {$[-2.15739]$} & {$[0.97352]$} & {$[3.51643]$} \\
\hline R2 & 0.776274 & & & \\
\hline Adj.R2 & $\mathbf{0 . 4 2 8 2 5 5}$ & & & \\
\hline F-Statistics & 2.230553 & & & \\
\hline
\end{tabular}

(Source: Author, 2021)

Group 2:

Table 5: Cointegration Equation of Group 2

\begin{tabular}{|l|l|l|l|l|}
\hline $\begin{array}{l}\text { Cointegrating } \\
\text { Eq: }\end{array}$ & CoinEq1 & CoinEq2 & CoinEq3 & CoinEq4 \\
\hline LEX(-1) & 1.000000 & 0.000000 & 0.000000 & 0.000000 \\
\hline BOP(-1) & 0.000000 & 1.000000 & 0.000000 & 0.000000 \\
\hline GDP(-1) & 0.000000 & 0.000000 & 1.000000 & 0.000000 \\
\hline IFN(-1) & 0.000000 & 0.000000 & 0.000000 & 1.000000 \\
\hline IT(-1) & -0.002457 & -0.086383 & 0.321783 & 0.020162 \\
\hline & $(0.00404)$ & $(0.11866)$ & $(0.05123)$ & $(0.00402)$ \\
\hline & {$[-0.60766]$} & {$[-0.72800]$} & {$[6.28090]$} & {$[-5.01756]$} \\
\hline LR(-1) & -0.005386 & -0.097163 & 0.052790 & 0.001787 \\
\hline & $(0.00084)$ & $(0.02452)$ & $(0.01059)$ & $(0.00083)$ \\
\hline & {$[-6.44618]$} & {$[-3.96227]$} & {$[4.98594]$} & {$[2.15198]$} \\
\hline
\end{tabular}

\begin{tabular}{|l|c|l|l|l|}
\hline $\mathrm{R}^{2}$ & 0.822454 & & & \\
\hline Adj.R2 ${ }^{2}$ & $\mathbf{0 . 5 4 6 2 7 0}$ & & & \\
\hline F-Statistics & 2.977926 & & & \\
\hline
\end{tabular}

(Source: Author, 2021)

From the Adjusted $\mathrm{R}^{2}$ of two groups, we can see that the Adj. $\mathrm{R}^{2}$ of Group 2 is approximately $54.63 \%$ higher than Group 1 (nearly 42.83\%). Basically, we can infer the variables in Group 2 can explain exchange rate better than variables in Group 1. Therefore, the hypothesis at first that "IFN, IT can explain better than IFD and ITD" at least is acceptable in this sample. That means, in the next section, we will only test the impulse response function, variance decomposition of variables and residual root test and Granger causality on the better-explained group, or group 2 .

Then the authors will focus on the Equation Estimates of Group 2. According to the Figure 15., the equation is estimated as the following:

$\mathrm{D}(\mathrm{LEX})=\mathrm{C}(1) *(\mathrm{LEX}(-1)-0.00245665422269 * \mathrm{IT}(-1)-$ $0.00538570865499 * \operatorname{LR}(-1) \quad-4.13682055445)+$ $\mathrm{C}(2) *($ BOP $(-1) \quad-\quad 0.0863828406642 * \mathrm{IT}(-1) \quad-$ $0.0971625037383 * \mathrm{LR}(-1)+2.81118575978)+$ $\mathrm{C}(3) *(\mathrm{GDP}(-1)+0.321784814287 * \mathrm{IT}(-1)+$ $0.0527896562856 * \mathrm{LR}(-1) \quad-10.1674285822)+$ $\mathrm{C}(4) *(\mathrm{IFN}(-1) \quad-\quad 0.0201616569133 * \mathrm{IT}(-1) \quad+$ $0.00178701997717 * \operatorname{LR}(-1)+0.0356364379697)+$ $\mathrm{C}(5) * \mathrm{D}(\operatorname{LEX}(-1))+\mathrm{C}(6) * \mathrm{D}(\operatorname{LEX}(-2))+$ $\mathrm{C}(7) * \mathrm{D}(\operatorname{LEX}(-3))+\mathrm{C}(8) * \mathrm{D}(\operatorname{LEX}(-4))+$ $\mathrm{C}(9) * \mathrm{D}(\mathrm{BOP}(-1))+\mathrm{C}(10) * \mathrm{D}(\mathrm{BOP}(-2))+$ $\mathrm{C}(11) * \mathrm{D}(\mathrm{BOP}(-3))+\mathrm{C}(12) * \mathrm{D}(\mathrm{BOP}(-4))+$ $\mathrm{C}(13) * \mathrm{D}(\mathrm{GDP}(-1))+\mathrm{C}(14) * \mathrm{D}(\mathrm{GDP}(-2))+$ $\mathrm{C}(15) * \mathrm{D}(\mathrm{GDP}(-3))+\mathrm{C}(16) * \mathrm{D}(\mathrm{GDP}(-4))+$ $\mathrm{C}(17) * \mathrm{D}(\operatorname{IFN}(-1))+\mathrm{C}(18) * \mathrm{D}(\operatorname{IFN}(-2))+$ $\mathrm{C}(19) * \mathrm{D}(\mathrm{IFN}(-3))+\mathrm{C}(20) * \mathrm{D}(\mathrm{IFN}(-4))+$ $\mathrm{C}(21) * \mathrm{D}(\mathrm{IT}(-1))+\mathrm{C}(22) * \mathrm{D}(\mathrm{IT}(-2))+\mathrm{C}(23) * \mathrm{D}(\mathrm{IT}(-3))$ $+\mathrm{C}(24) * \mathrm{D}(\mathrm{IT}(-4))+\mathrm{C}(25) * \mathrm{D}(\mathrm{LR}(-1))+$ $\mathrm{C}(26) * \mathrm{D}(\mathrm{LR}(-2))+\mathrm{C}(27) * \mathrm{D}(\mathrm{LR}(-3))+$ $\mathrm{C}(28) * \mathrm{D}(\mathrm{LR}(-4))+\mathrm{C}(29)$

And the P-Value of the coefficients in the following summary table:

Table 6: P-Value of coefficients of Group 2

\begin{tabular}{|c|c|c|c|c|}
\hline & "Coefficient & "Std. Error & t-Statistic & Prob. \\
\hline 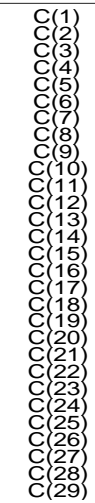 & 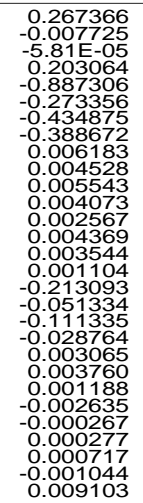 & 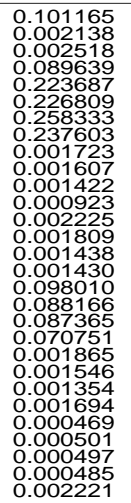 & 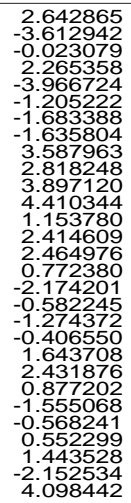 & 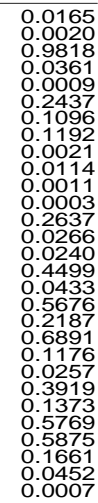 \\
\hline
\end{tabular}


(Source: Author, 2021)

As the result, $\mathrm{C}(1), \mathrm{C}(2), \mathrm{C}(4), \mathrm{C}(5), \mathrm{C}(9), \mathrm{C}(11), \mathrm{C}(12)$, $C(14), C(15), C(17), C(22), C(28), C(29)$ are significant with $\mathrm{P}$-Value is smaller than $5 \%$, and $\mathrm{R}^{2}$ is pretty good, F-Statistic is significant too, therefore, the data fitted well with the model.

\subsubsection{Granger causality}

Granger causality test is well-known as a Wald F-test in finding causality in short-run, by putting the coefficients of all variables in lagged differences in equation (2) respectively equal to zero. Buy using EViews 9.5, we have the summary table of Granger Causality result as below:

Table 7: Summary of Granger Causality

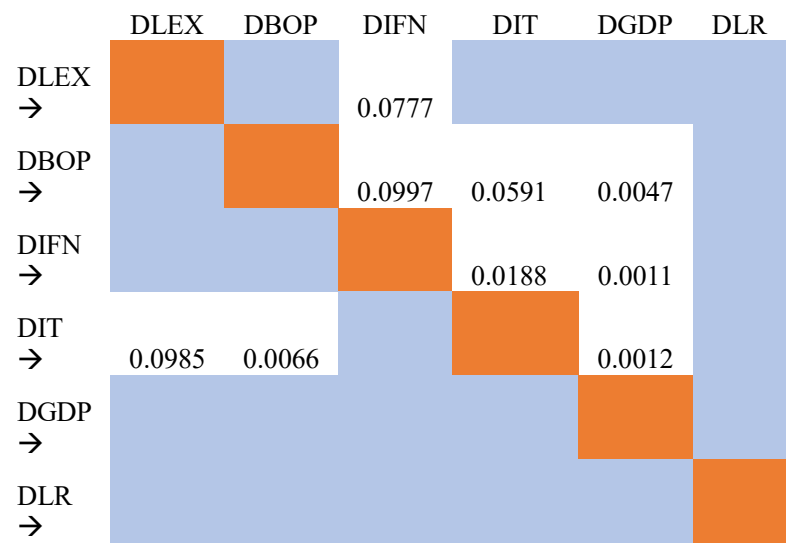

(Source: Author, 2021)

From the table above, we can see that at the 10 percent level of significance only has Interest rate does Granger cause exchange rate in short-run, and Exchange rate is only variable that does Granger cause Inflation in the short-run horizon.

Moreover, we have another short-run Granger causality from BOP to IFN, BOP to IT, BOP to GDP at $10 \%, 10 \%$, and $5 \%$ of significance respectively; IFN to IT, IFN to GDP at $10 \%$ and $5 \%$ respectively; and IT to BOP, IT to GDP at same level of 5\%.

Interestingly, GDP has mainly influence to Exchange rate (about 19.35\% in decomposition analysis at lag length 4) in the long-run horizon, however, in short-run, GDP doesn't Granger-cause Exchange rate.

\subsubsection{Impulse Response Function}

From the figure above, we will analyze the impulse response of Exchange rate to other variables, in the order from left to right and from top to bottom:

(1) LEX to LEX: the historical Exchange rate strongly positive affecting the future exchange rate in the first stage, however, the impact is weaker by time, especially after period 10 .

(2) LEX to BOP: the blue line is under the horizontal line expresses that Exchange rate response to BOP in a negative way. It means in the long-run, a surplus current account of the balance of payment would restrain the Exchange rate volatility.

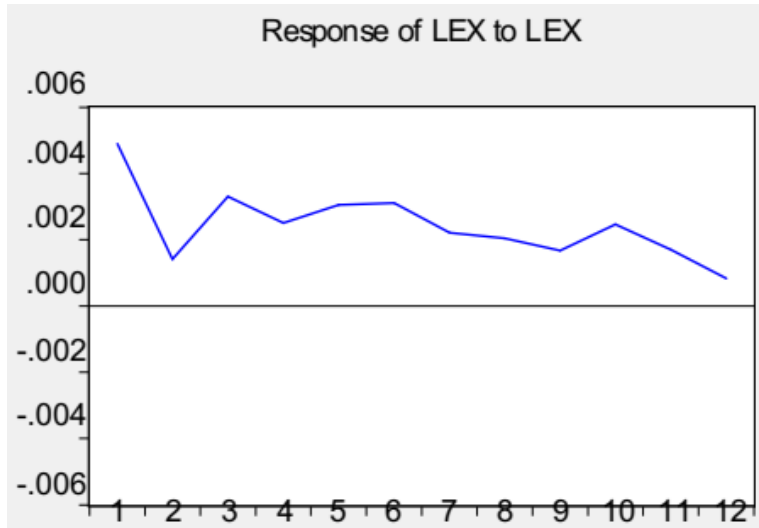

Response of LEX to GDP

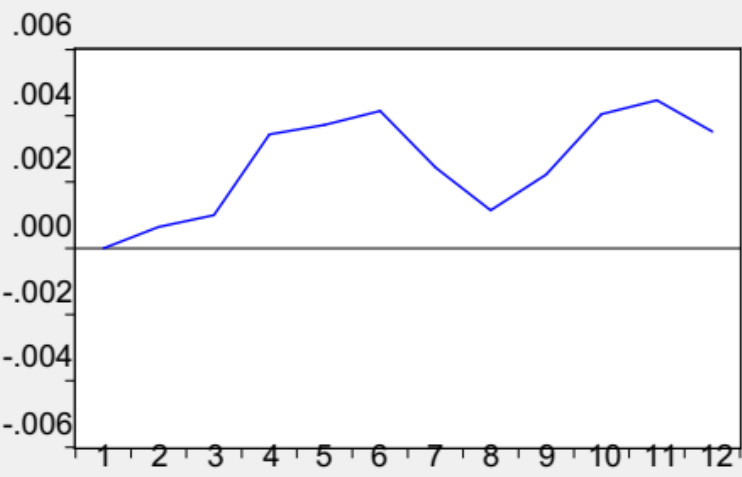

Response of LEX to IT

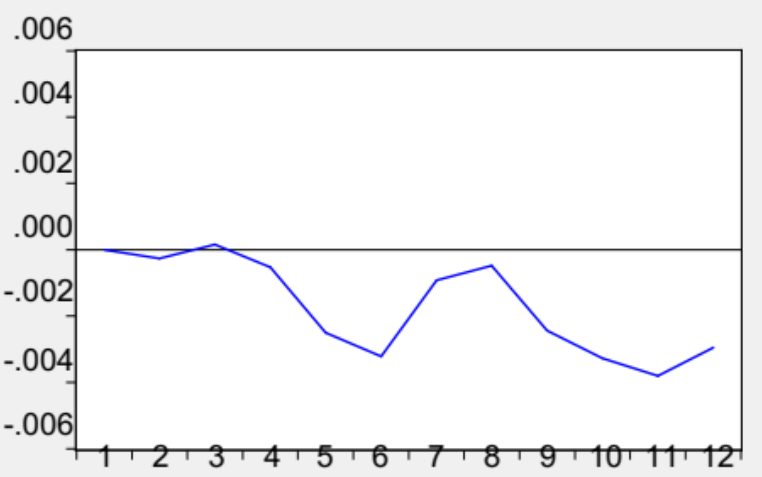




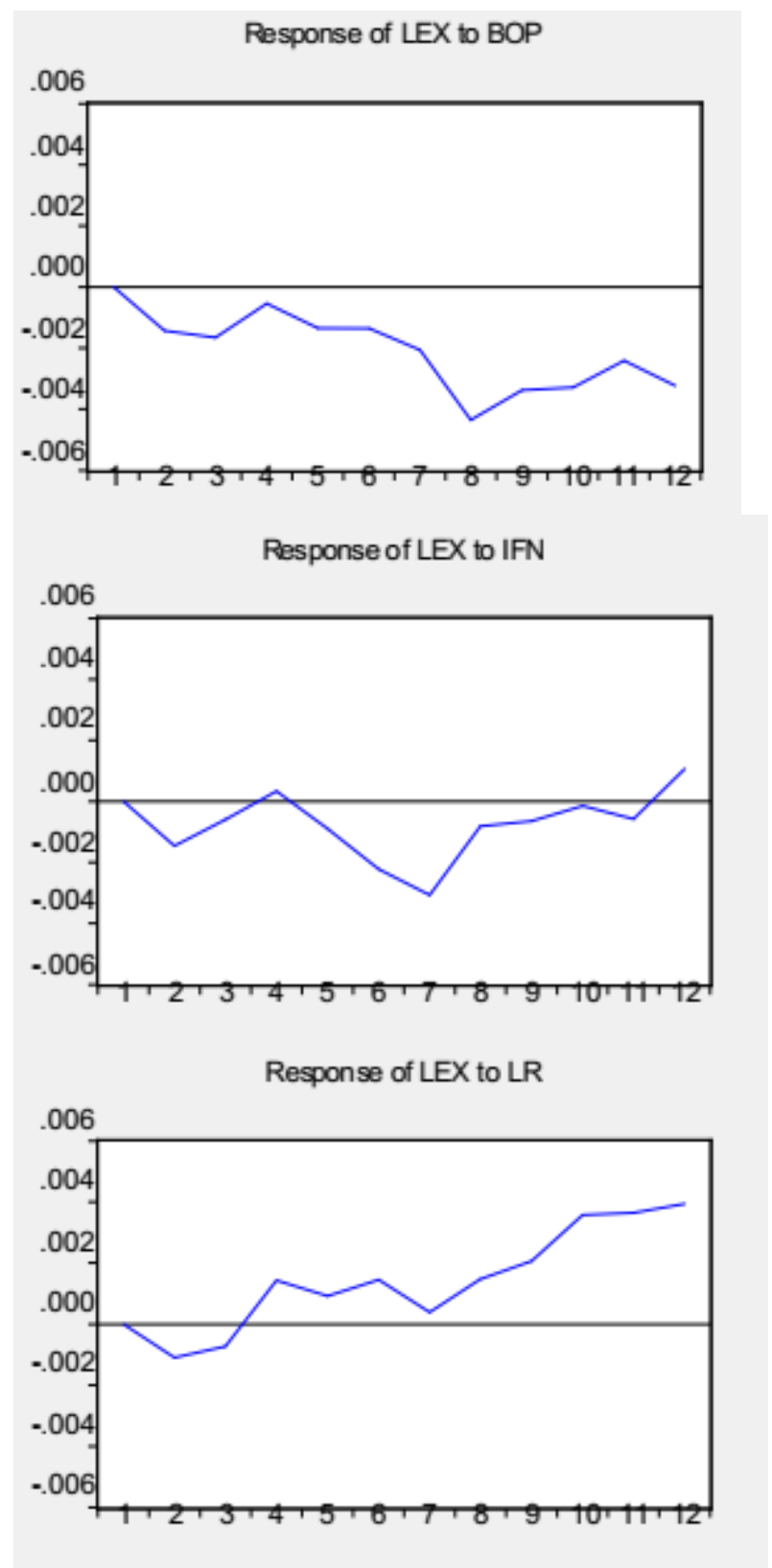

Fig.1 Response to Chelosky One S.D. Innovations (Source: Author, 2021)

Conservely, a deficit balance of payment would increase the exchange rate. The model once again support for the economic fact.

(3) LEX to GDP: generally, GDP has a positive impact to exchange rate in the long-run horizons, but the impact rises up and down frequently.

(4) LEX to IFN: overall, the Inflation has neutral impact to exchange rate in long-term when the blue line fluctuates around the horizontal line, however, the impact is remarkable in period 6-7, when the impact hits the bottom before raising.

(5) LEX to IT: Exchange rate gives a negative response to inflation impulse in long-run with large fluctuation.
(6) LEX to Reserves: the first response of Exchange rate to a shock in Reserves negative, but in the next 3 periods, the response surprisingly arising and positive.

\subsubsection{Variance Decomposition}

We have:

At period 4 (lag length 4), we can see the exchange rate is decomposed from approximately $63.30 \%$ LEX, $7.43 \%$ BOP, $19.35 \%$ GDP, 3.80\% IFN, 0.54\% IT, and 5.58\% LR. We can guest GDP is the main factor influence exchange rate in the independent variables, and BOP is the second one.

Table 8: Cholesky Ordering

\begin{tabular}{cccccccc}
\hline Period & S.E. & LEX & BOP & GDP & IFN & IT & LR \\
\hline \hline 1 & 0.0048995 & 100.0000 & 0.000000 & 0.0000000 & 0.000000 & 0.000000 & 0.000000 \\
2 & 0.005640 & 81.55059 & 6.441034 & 1.314589 & 6.661532 & 0.2218655 & 3.810392 \\
3 & 0.0068683 & 77.83300 & 10.06324 & 2.974128 & 5.230976 & 0.197825 & 3.700827 \\
4 & 0.008256 & 63.29504 & 7.430047 & 19.35409 & 3.8035808 & 0.538060 & 5.579172 \\
5 & 0.010054 & 51.88364 & 6.810376 & 26.77369 & 3.364725 & 6.567576 & 4.599995 \\
6 & 0.012130 & 42.21581 & 5.926870 & 30.05419 & 5.657334 & 11.55532 & 4.590468 \\
7 & 0.013138 & 38.82426 & 7.508314 & 29.04531 & 10.28240 & 10.34214 & 3.997585 \\
8 & 0.014145 & 35.59320 & 15.92240 & 25.71606 & 9.201335 & 9.0385008 & 4.528506 \\
9 & 0.015160 & 32.20120 & 18.82702 & 24.52896 & 8.189146 & 10.46814 & 5.785532 \\
10 & 0.016930 & 27.94677 & 18.87246 & 25.38108 & 6.575036 & 12.13245 & 9.092203 \\
\hline \hline
\end{tabular}

Cholesky Ordering: LEX BOP GDP IFN IT LR

(Source: Author, 2021)

\subsubsection{Residual Unit Root Test}

According to Figure 16., all the residuals are stationary. Thus, all the results are consistent, and the model used is fitted to explain the exchange rate in long-run.

\subsubsection{Forecasting model}

In order to test the forecasting power of the model, the authors runs the foresting function of Eviews 9.5 and found a result in figure 19., the result is quite good with a small Root Mean Square Error is 0.003029 (the lower RMSE is, the better model can forecast); the Theil inequality coefficient is 0.000353 , it is a good result, because Theil inequality coefficient is close to zero; and the Bias Proportion is the gap between the mean of actual exchange rate and the mean of predicted exchange rate, approximately $0.0000 \%$, therefore the model is quite good.

\subsection{Discussion}

Back to the two initial questions that the authors aimed to answer, the result points out that the main endogenous factor (excluding exchange rate) affecting exchange rate within chosen variables is GDP, however, its role is significant only in the long-run. Whereas, in the short-run, only Interest rate factor does Granger-cause Exchange rate. And surprisingly, a shock of Reverses only helps to restrain Exchange rate volatility in the short-run, but can not help in long run, especially after period 9. This response may imply that in the long-run, Reserves should not be used as an instrument to restrain Exchange rate in 
Vietnam in the long-term. Additionally, other variables have long-run affecting to exchange rate in a different level of significance.

In general, the paper introduced an acceptable model to explain variables affecting to exchange rate, as well as forecasting exchange rate with adjusted $\mathrm{R}^{2}$ is nearly $54.63 \%$ and $\mathrm{P}$-value is signification $(\mathrm{P}$-value $=0.936 \%)$. The result of the paper is quite promising compared with other studies in Vietnam. However, with the limited time, data and experience, the authors will leave the forecasting part with the deeper analysis in the within-sample and out-of-sample for the further study. Especially when the sample large enough, we might have a better look at the exchange rate movement after some monetary policy of the government.

However, this study is not perfect. As other previous studies, it have some main problems: First, the research could not include for all factors affecting exchange rate, due to this will complicate the overall result and achieve nothing in the end; secondly, the effect of administrative command or policy from government are not included also since they cannot be quantified and they change constantly to fit with the new exchange rate itself. For the goal of this paper, the authors exclude these short-coming for the overall conclusion

\section{CONCLUSION}

In this paper, the authors introduced a macroeconomic model to examine the factors affecting the USD/VND exchange rate. The model is learned from many other studies, but still, have the limitation of its own, for example: the authors chose the variables based on other studies, however, they could not represent for all factors affecting exchange rate, or the effect of administrative command or policy from government cannot be quantified.

The main positive results of the paper are along with supporting some proven studies that the factors were chosen has long-run or short-run affecting to exchange rate, it found some facts that: GDP affecting Exchange rate in long-run, Interest rate influence exchange and have a positive effecting in the long-run horizon. Then have some implication for government in exchange rate intervention policy.

For other organizations such as import-export firms and commercial banks, they can take advantage of the model to develop a tool in preventing the risk of exchange rate fluctuation. And for further study, the authors hopes that gives an idea in approaching USD/VND exchange rate, and it should be reviewed with larger sample and observations as well as another group of variables.

\section{REFERENCES}

\section{Vietnamese}

[1]. Nguyễn Kim Nam, Trương Ngọc Hảo, Nguyễn Thị Hằng Nga (2014). Tác động truyền dẫn tỷ giá hối đoái đến lạm phát của
Việt Nam, Tạp chí Công nghệ Ngân hàng, Số 105, Tháng 12/2014, tr.3-10.

[2]. Trần Văn Hùng (2015). Tác động truyền dẫn tỷ giá đến lạm phát qua phuoong pháp kinh tế lượng phi tuyến, Tạp chí Tài chính, Tháng 9/2015, tr.16-18.

[3]. Hoàng Đình Minh (2014). Mối quan hệ giũa lạm phát và tỷ giá hối đoái trong nền kinh tế Việt Nam, Luận án tiến sỹ, dòng 3-10, tr.11.

[4]. Hà Thị Ngọc Lan (2016). Úng dụng mô hình VAR trong phân tích nhân tố ảnh hương đến tỷ giá USD/VND và dụ báo tỷ giá USD/VND, Luận văn, Đại học Kinh tế Huế.

[5]. Trần Văn Hùng (2015). Tác động truyền dẫn tỷ giá hối đoái đến lạm phát tại Việt Nam, Tạp chí Tài chính, Tạp chí Tài chính online.

[6]. Ngân hàng nhà nước Việt Nam (2015). Quyết định số 2730/QD-NHNN ngày 31/12/2015: Về việc công bố tỷ giá trung tâm của đồng Việt Nam với Đô la Mỹ, tỷ giá tính chéo của đồng Việt Nam với một số ngoại tẹ khác.

[7]. Phương Linh (2016), Cách thưc điều hành tỷ giá mới được các chuyên gia đánh giá cao, https://www.sbv.gov.vn.

\section{English}

[8]. Nguyen Quang My (2016), The impact of Economic Factors on the Foreign Exchange Rates between USA and Four Big Emerging countries: China, India, Brazil and Mexico, International Finance and Banking, 2016, Vol.3, No.1, ISSN 2374-2089.

[9]. Martins Iyoboyi, Olarinde Muftau \& David McMillan (2014). Impact of exchange rate depreciation on the balance of payments: Empirical evidence from Nigeria, Cogent Economics

Finance, 2:1, DOI: 10.1080/23322039.2014.9 23323

[10]. Shabana Parveen, Abdul Qayyum Khan, Muammad Ismail (2012). Analysis of the Factors affecting exchange rate variability in Pakistan, Academic Research International, Vol.2, No.3, May 2012.

[11]. Ng Yuen-Ling, Har Wai-Mun (Coressponding author), Tan Geoi-Mei (2008). Real exchange rate and Trade Balance relationship: An empirical Study on Malaysia, International Journal of Business and Management, Vol.3, No.8.

[12].Vo Van Minh (2009). Exchange rate pass-through and its implication for inflation in Vietnam, Vietnam Development Forum, Working paper 0902 
[13].Fadli Fizari Abu Hassan Asari, Nurul Syuhada Baharuddin, Nurmadihah Jusoh, Zuraida Mohamad, Norazidah Shamsudin and Kamaruzaman Jusoff (2011). A Vector Error Correction Model (VECM) Approach in Explaining the Relationship Between Interest Rate and Inflation Towards Exchange Rate Volatility in Malaysia, World Applied Sciences Journal 12 (Special Issue on Bolstering Economic Sustainability): 49-56, 2011 ISSN 1818-4952

[14].Jorge Canales-Kriljenko and Karl Habermeier (2004). Structural Factors affecting Exchange rate Volatility: A cross-section Study, IMF Working Paper WP/04/147.

[15].Peter Isard (2007). Equilibrium Exchange rates: Assessment Methodologies, IMF working paper No. WP/07/296.

[16].Gerald P. Dwyer (2015). The Johansen Tests for Cointegration, April 2015.

[17].Mai Thu Hien (2007). Solutions for exchange rate policy of transition economy of Vietnam, July 2007

\section{Website}

[18]. Tổng cụ hải quan Việt Nam (2017), Xuất nhập khẩu hàng hoá của Việt Nam đạt mốc
400

tỷ

USD, https://www.customs.gov.vn/Lists/ThongKeH aiQuan/ViewDetails.aspx?ID=1225\&Categor $\mathrm{y}=\mathrm{Phân} \% 20 \mathrm{t} \% \mathrm{C} 3 \% \mathrm{ADch} \% 20$ chuyên $\% 20$ đề \& Group=Phân\%20t\%C3\%. Retrieved on December 19, 2017.

[19].Theo Bergen J.V, 2018, Six factors that influence Exchange rate. https://www.investopedia.com/articles/bas ics/04/050704.asp. Retrieved March 1, 2018

[20].The Economic Times, https://economictimes.indiatimes.com/definiti on/core-inflation. Retrieved May 102018.

[21].Trading Economics, https://tradingeconomics.com/united-states/co re-inflation-rate. Retrieved May 10, 2018.

[22].Johansen test. (2017). https://en.wikipedia.org/wiki/Johansen_test. Retrieved May 24, 2017.

[23].EViews

Help. http://www.eviews.com/help/helpintro.html\#p age/content/coint-Johansen_Cointegration_Te st.html. Re 
ATLANTIS

Advances in Economics, Business and Management Research, volume 196

7. APPENDIX

1. The plot of series, 2005Q1-2017Q4:

BOP

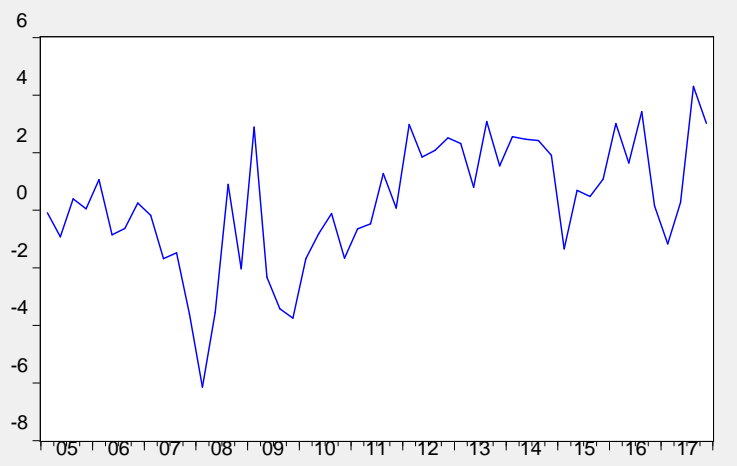

IED

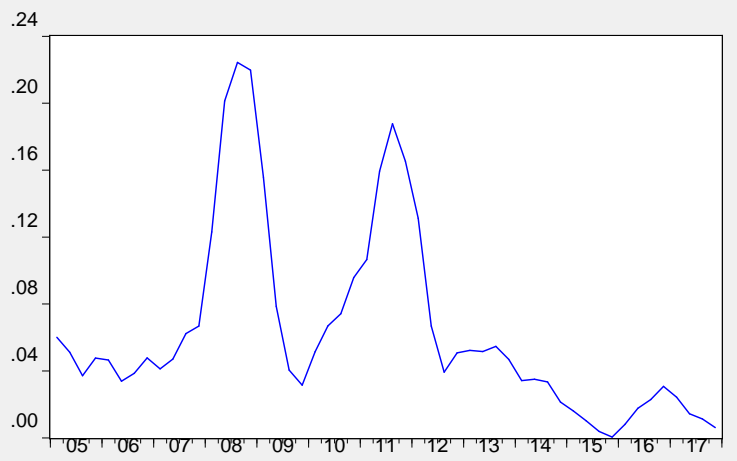

IT

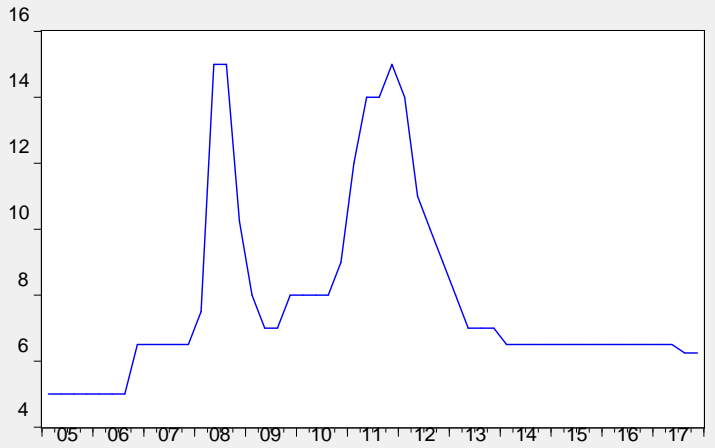

GDP

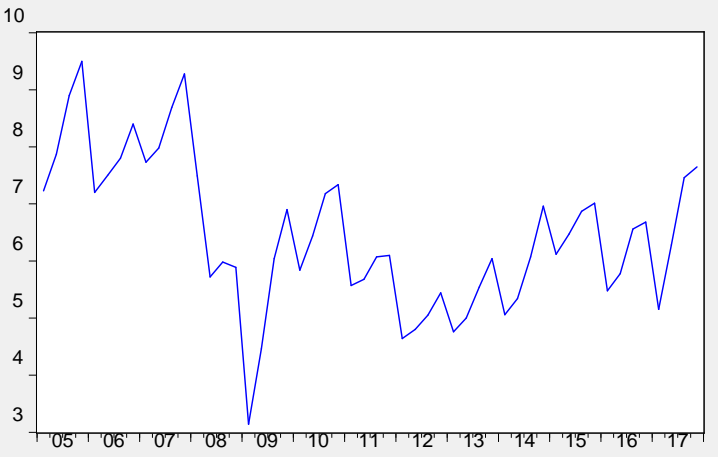

AFN

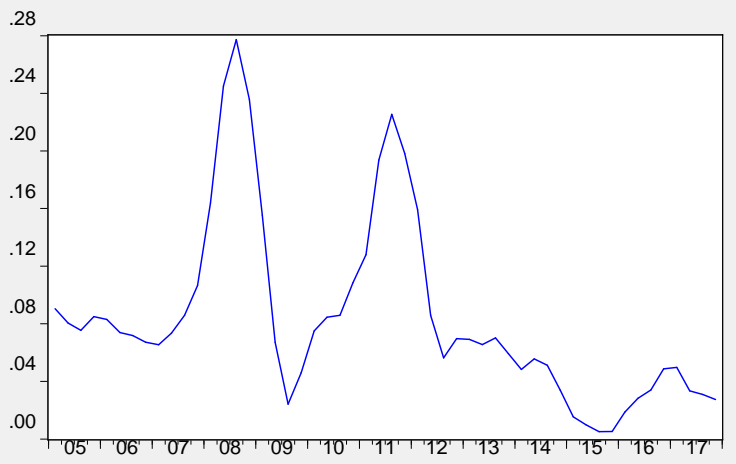

ITO

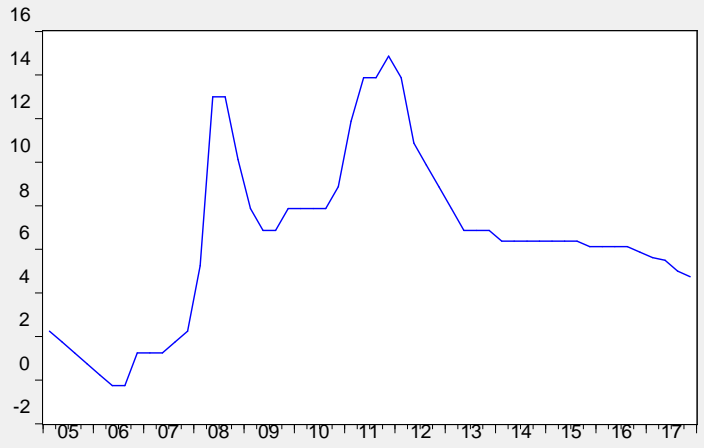

516 
LEX

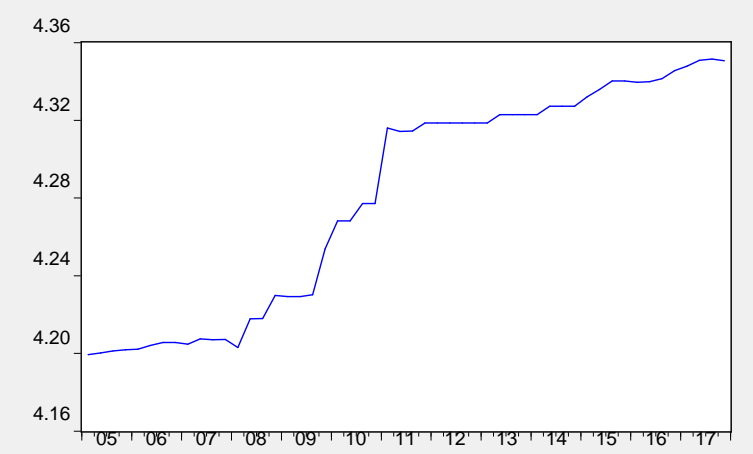

LR

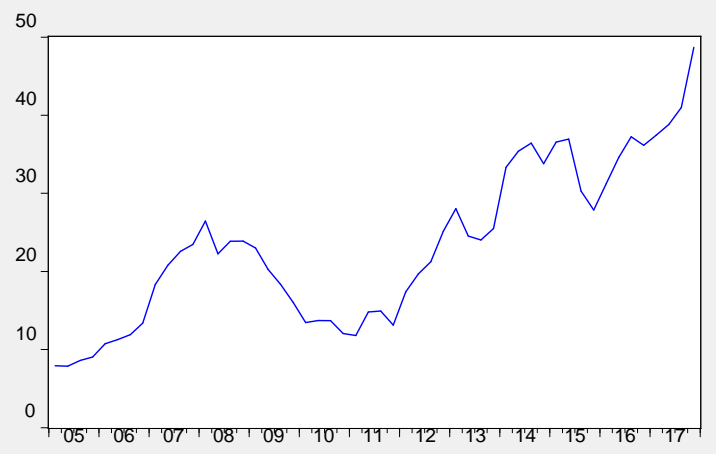

50

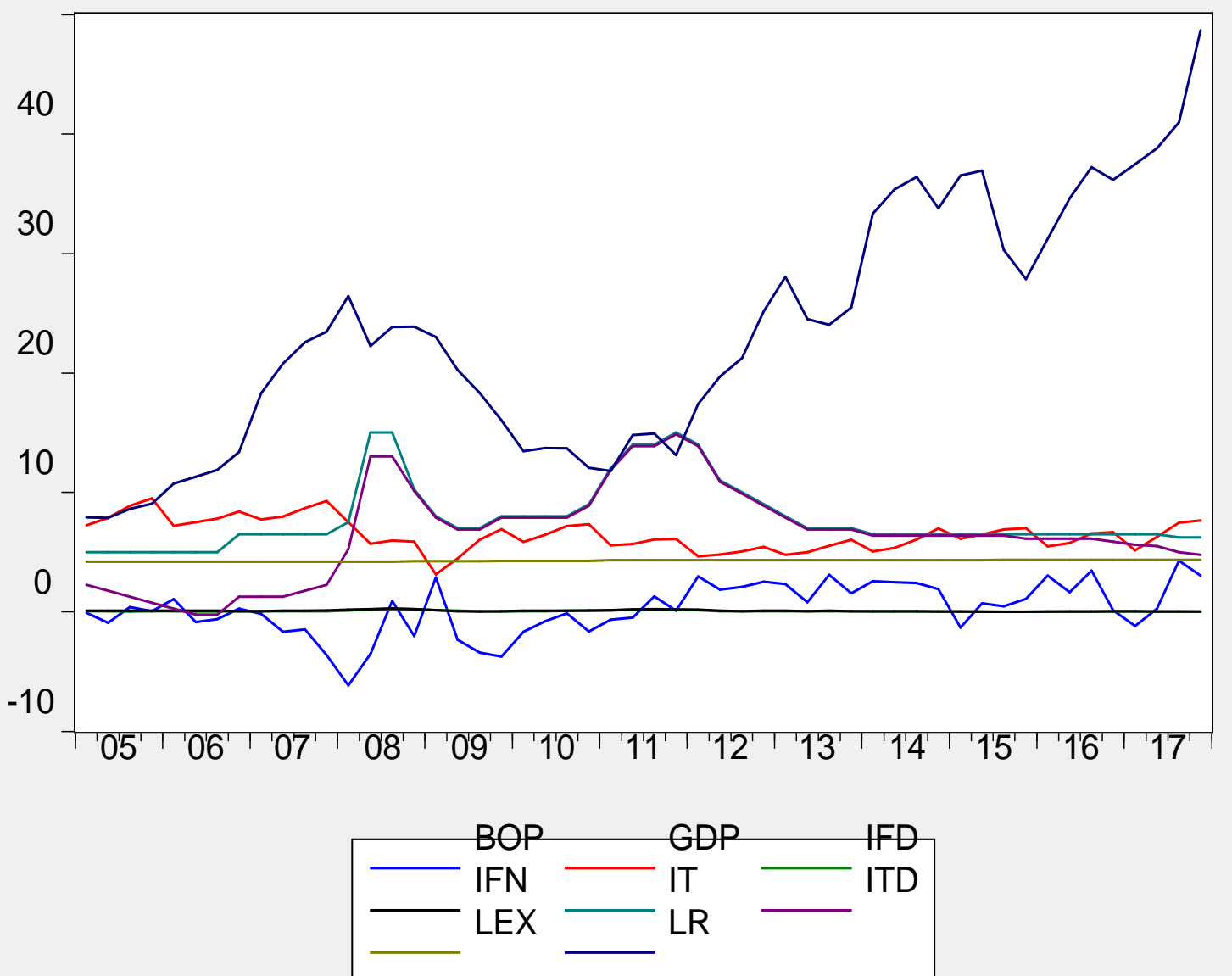




\section{Unit root test}

Fig.2: Unit root test of BOP - Balance of Payment - current account

\begin{tabular}{|c|c|c|c|c|c|c|c|c|c|}
\hline \multicolumn{5}{|c|}{ Level } & \multicolumn{5}{|c|}{ First difference } \\
\hline \multicolumn{5}{|c|}{$\begin{array}{l}\text { Null Hypothesis: BOP has a unit root } \\
\text { Exogenous: Constant, Linear Trend } \\
\text { Lag Length: } 1 \text { (Fixed) }\end{array}$} & \multicolumn{5}{|c|}{$\begin{array}{l}\text { Null Hypothesis: } \mathrm{U}(\mathrm{BUY}) \text { has a unit root } \\
\text { Exogenous: Constant, Linear Trend } \\
\text { Lag Length: } 1 \text { (Fixed) }\end{array}$} \\
\hline & & & t-Statistic & Prob.* & & & & t-Statistic & Prob.* \\
\hline \multicolumn{3}{|c|}{$\begin{array}{cc}\text { Augmented Dickey-Fuller test statistic } \\
\text { Test critical values: } & 1 \% \text { level } \\
& 5 \% \text { level } \\
& 10 \% \text { level } \\
\end{array}$} & $\begin{array}{l}-3.276897 \\
-4.152511 \\
-3.502373 \\
-3.180699\end{array}$ & 0.0819 & \multicolumn{3}{|c|}{$\begin{array}{lc}\text { Augmented Dickey-Fuller test statistic } \\
\text { Test critical values: } & 1 \% \text { level } \\
& 5 \% \text { level } \\
& 10 \% \text { level } \\
\end{array}$} & $\begin{array}{l}-5.795892 \\
-4.156734 \\
-3.504330 \\
-3.181826\end{array}$ & 0.0001 \\
\hline \multicolumn{5}{|c|}{$\begin{array}{l}\text { Augmented Dickey-Fuller Test Equation } \\
\text { Dependent Variable: D(BOP) } \\
\text { Method: Least Squares } \\
\text { Date: 05/13/18 Time: } 03: 05 \\
\text { Sample (adjusted): } 2005 \mathrm{Q} 2017 \mathrm{2} 2017 \\
\text { Included observations: } 50 \text { after adjustments }\end{array}$} & \multicolumn{5}{|c|}{$\begin{array}{l}\text { Augmented Dickey-Fuller Test Equation } \\
\text { Dependent Variable: D }(B O P, 2) \\
\text { Method: Least Squares } \\
\text { Date: 05/13/18 time: 03:06 } \\
\text { Sample (adjusted): } 2005 \mathrm{Q} 42017 \mathrm{Q} 4 \\
\text { Included observations: } 49 \text { after adjustments }\end{array}$} \\
\hline Variable & Coefficient & Std. Error & t-Statistic & Prob. & Variable & Coefficient & Std. Error & t-Statistic & Prob. \\
\hline $\begin{array}{c}\mathrm{BOP}(-1) \\
\mathrm{D}(\mathrm{BOP}(-1)) \\
\mathrm{C}(" 2005 \mathrm{Q} 1 ")\end{array}$ & $\begin{array}{r}-0.519380 \\
-0.100805 \\
-0.988012 \\
0.044515\end{array}$ & $\begin{array}{l}0.158497 \\
0.148063 \\
0.585730 \\
0.020564\end{array}$ & $\begin{array}{r}-3.276897 \\
-0.680825 \\
-1.686803 \\
2.164730\end{array}$ & $\begin{array}{l}0.0020 \\
0.4994 \\
0.0984 \\
0.0356\end{array}$ & $\begin{array}{c}\mathrm{D}(\mathrm{BOP}(-1)) \\
\mathrm{D}(\mathrm{BOP}(-1), 2) \\
\mathrm{C}(-2005 \mathrm{Q} 1 ") \\
\text { @TREND("200 }\end{array}$ & $\begin{array}{r}-1.439162 \\
0.058867 \\
-0.180028 \\
0.010167\end{array}$ & $\begin{array}{l}0.248307 \\
0.154047 \\
0.600374 \\
0.019724 \\
\end{array}$ & $\begin{array}{r}-5.795892 \\
0.382136 \\
-0.299860 \\
0.515448 \\
\end{array}$ & $\begin{array}{l}0.0000 \\
0.7042 \\
0.7657 \\
0.6088 \\
\end{array}$ \\
\hline $\begin{array}{l}\text { R-squared } \\
\text { Adjusted R-squared } \\
\text { S.E. of regression } \\
\text { Sum squared resid } \\
\text { Log likelihood } \\
\text { F-statistic } \\
\text { Prob(F-statistic) }\end{array}$ & $\begin{array}{r}0.296631 \\
0.250759 \\
1.745321 \\
140.1227 \\
-96.70932 \\
6.466507 \\
0.000959\end{array}$ & \multicolumn{2}{|c|}{$\begin{array}{l}\text { Mean dependent var } \\
\text { S.D. dependent var } \\
\text { Akaike info criterion } \\
\text { Schwarz criterion } \\
\text { Hannan-Quinn criter. } \\
\text { Durbin-Watson stat }\end{array}$} & $\begin{array}{l}0.078734 \\
2.016344 \\
4.028373 \\
4.181335 \\
4.086622 \\
1.952186\end{array}$ & $\begin{array}{l}\text { R-squared } \\
\text { Adjusted R-squared } \\
\text { S.E. of regression } \\
\text { Sum squared resid } \\
\text { Log likelihood } \\
\text { F-statistic } \\
\text { Prob(F-statistic) }\end{array}$ & $\begin{array}{r}0.680817 \\
0.659538 \\
1.949424 \\
171.0114 \\
-100.1508 \\
31.99500 \\
0.000000\end{array}$ & \multicolumn{2}{|c|}{$\begin{array}{l}\text { Mean dependent var } \\
\text { S.D. dependent var } \\
\text { Akaike info criterion } \\
\text { Schwarz criterion } \\
\text { Hannan-Quinn criter. } \\
\text { Durbin-Watson stat }\end{array}$} & $\begin{array}{r}-0.052966 \\
3.340967 \\
4.251053 \\
4.405487 \\
4.309645 \\
2.026916\end{array}$ \\
\hline
\end{tabular}

Fig.3: Unit root test of GDP growth rate

\begin{tabular}{|c|c|c|c|c|c|c|c|c|c|}
\hline \multicolumn{5}{|c|}{ Level } & \multicolumn{5}{|c|}{ First difference } \\
\hline \multicolumn{5}{|c|}{$\begin{array}{l}\text { Null Hypothesıs: Gur nas a unit root } \\
\text { Exogenous: Constant, Linear Trend } \\
\text { Lag length: } 7 \text { (Automatic - based on SIC, maxlag=10) }\end{array}$} & \multicolumn{5}{|c|}{$\begin{array}{l}\text { Null Hypothesis: D(GDP) has a unit root } \\
\text { Exogenous: Constant, Linear Trend } \\
\text { Lag Length: } 10 \text { (Automatic - based on SIC, maxlag=10) }\end{array}$} \\
\hline & & & t-Statistic & Prob.* & & & & t-Statistic & Prob. ${ }^{*}$ \\
\hline \multicolumn{3}{|c|}{$\begin{array}{lc}\text { Augmented Dickey-Fuller test statistic } \\
\text { Test critical values: } \quad 1 \% \text { level } \\
& 5 \% \text { level } \\
& 10 \% \text { level }\end{array}$} & $\begin{array}{l}-0.640822 \\
-4.180911 \\
-3.515523 \\
-3.188259\end{array}$ & 0.9713 & \multicolumn{3}{|c|}{$\begin{array}{cc}\text { Augmented Dickey-Fuller test statistic } \\
\text { Test critical values: } & 1 \% \text { level } \\
& 5 \% \text { level } \\
& 10 \% \text { level } \\
\end{array}$} & $\begin{array}{l}-4.441725 \\
-4.205004 \\
-3.526609 \\
-3.194611 \\
\end{array}$ & 0.0054 \\
\hline \multirow{2}{*}{\multicolumn{3}{|c|}{$\begin{array}{l}\text { Augmented Dickey-Fuller Test Equation } \\
\text { Dependent Variable: D(GDP) } \\
\text { Method: Least Squares } \\
\text { Date: } 05 / 11 / 18 \text { ime: } 10: 50 \\
\text { Sample (adjusted): } 2007 \mathrm{Q} 12017 \mathrm{Q} 4 \\
\text { Included observations: } 44 \text { after adjustments }\end{array}$}} & & & \multicolumn{5}{|c|}{ 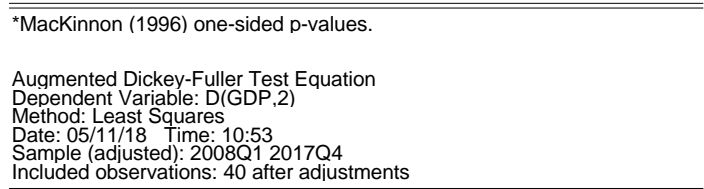 } \\
\hline & & & & & Variable & Coefficient & Std. Error & t-Statistic & $\overline{\text { Prob. }}$ \\
\hline Variable & Coefficient & Std. Error & t-Statistic & Prob. & \multirow[b]{2}{*}{$\begin{array}{c}\mathrm{D}(\mathrm{GDP}(-1)) \\
\mathrm{D}(\mathrm{GDP}(-1), 2) \\
\mathrm{D}(\mathrm{GDP}(-2), 2) \\
\mathrm{D}(\mathrm{GDP}(-3), 2) \\
\mathrm{D}(\mathrm{GDP}(-4), 2) \\
\mathrm{D}(\mathrm{GDP}(-5), 2) \\
\mathrm{D}(\mathrm{GDP}(-6), 2) \\
\mathrm{D}(\mathrm{GDP}(-7), 2 \\
\mathrm{D}(\mathrm{GDP}(-8), 2 \\
\mathrm{D}(\mathrm{GDP}(-9), 2) \\
\mathrm{D}(\mathrm{GDP}(-10), 2) \\
\text { @TREND("2005Q1") } \\
\text { @TREND("2005) }\end{array}$} & \multirow[b]{2}{*}{$\begin{array}{r}-3.364285 \\
2.198420 \\
1.994749 \\
2.032539 \\
2.076877 \\
1.420248 \\
0.930323 \\
0.586543 \\
0.665947 \\
0.623063 \\
0.438514 \\
-1.070056 \\
0.030090\end{array}$} & \multirow[b]{2}{*}{$\begin{array}{l}0.757428 \\
0.688386 \\
0.633899 \\
0.558875 \\
0.475673 \\
0.439766 \\
0.372358 \\
0.341786 \\
0.267914 \\
0.201224 \\
0.141779 \\
0.324558 \\
0.009223\end{array}$} & \multirow[b]{2}{*}{$\begin{array}{r}-4.441725 \\
3.193587 \\
3.146792 \\
3.636842 \\
4.366183 \\
3.229556 \\
2.498463 \\
1.716112 \\
2.485669 \\
3.096359 \\
3.092946 \\
-3.296965 \\
3.262406\end{array}$} & \multirow[b]{2}{*}{$\begin{array}{l}0.0001 \\
0.0036 \\
0.0040 \\
0.0011 \\
0.0002 \\
0.0032 \\
0.0189 \\
0.0976 \\
0.0194 \\
0.0045 \\
0.0046 \\
0.0027 \\
0.0030\end{array}$} \\
\hline 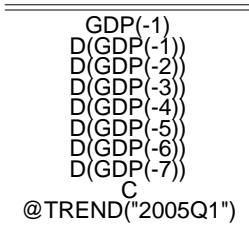 & $\begin{array}{r}-0.086553 \\
0.014511 \\
-0.286834 \\
0.004249 \\
0.297333 \\
-0.451398 \\
-0.239155 \\
-0.386514 \\
0.146823 \\
0.011281\end{array}$ & $\begin{array}{l}0.135065 \\
0.181611 \\
0.168744 \\
0.144042 \\
0.140002 \\
0.145377 \\
0.149894 \\
0.153660 \\
1.060138 \\
0.009639\end{array}$ & $\begin{array}{r}-0.640822 \\
0.079903 \\
-1.699817 \\
0.029501 \\
2.123779 \\
-3.105005 \\
-1.595499 \\
-2.515390 \\
0.138495 \\
1.170416\end{array}$ & $\begin{array}{l}0.5259 \\
0.9368 \\
0.0983 \\
0.9766 \\
0.0410 \\
0.0038 \\
0.1199 \\
0.0168 \\
0.8907 \\
0.2500\end{array}$ & & & & & \\
\hline $\begin{array}{l}\text { R-squared } \\
\text { Adjusted R-squared } \\
\text { S.E. of regression } \\
\text { Sum squared resid } \\
\text { Log likelihood } \\
\text { F-statistic } \\
\text { Prob(F-statistic) }\end{array}$ & $\begin{array}{r}0.696031 \\
0.615569 \\
0.602207 \\
12.33022 \\
-34.44630 \\
8.650401 \\
0.000001\end{array}$ & \multicolumn{2}{|c|}{$\begin{array}{l}\text { Mean dependent var } \\
\text { S.D. dependent var } \\
\text { Akaike info criterion } \\
\text { Schwarz criterion } \\
\text { Hannan-Quinn criter. } \\
\text { Durbin-Watson stat }\end{array}$} & $\begin{array}{l}-0.017045 \\
0.971263 \\
2.020286 \\
2.425784 \\
2.170664 \\
1.802743\end{array}$ & $\begin{array}{l}\text { R-squared } \\
\text { Adjusted R-squared } \\
\text { S.E. of regression } \\
\text { Sum squared resid } \\
\text { Log likelihood } \\
\text { F-statistic } \\
\text { Prob(F-statistic) }\end{array}$ & $\begin{array}{r}0.920396 \\
0.885017 \\
0.489950 \\
6.481384 \\
-20.35863 \\
26.01508 \\
0.000000\end{array}$ & \multicolumn{2}{|c|}{$\begin{array}{l}\text { Mean dependent var } \\
\text { S.D. dependent var } \\
\text { Akaike info criterion } \\
\text { Schwarz criterion } \\
\text { Hannan-Quinn criter. } \\
\text { Durbin-Watson stat }\end{array}$} & $\begin{array}{r}-0.010000 \\
1.444892 \\
1.667932 \\
2.216817 \\
1.866391 \\
2.152789\end{array}$ \\
\hline
\end{tabular}


Fig. 4: Unit root test of IFN - Inflation

\begin{tabular}{|c|c|c|c|c|c|c|c|c|c|}
\hline \multicolumn{5}{|c|}{ Level } & \multicolumn{5}{|c|}{ First difference } \\
\hline \multicolumn{5}{|c|}{$\begin{array}{l}\text { Null Hypothesis: IFN has a unit root } \\
\text { Exogenous: Constant, Linear Trend } \\
\text { Lag Length: } 2 \text { (Fixed) }\end{array}$} & \multicolumn{5}{|c|}{$\begin{array}{l}\text { Null Hypothesis: D(IFN) has a unit root } \\
\text { Exogenous: Constant, Linear Trend } \\
\text { Lag Length: } 2 \text { (Fixed) }\end{array}$} \\
\hline & & & t-Statistic & Prob. $^{*}$ & & & & t-Statistic & Prob. ${ }^{*}$ \\
\hline \multicolumn{3}{|c|}{$\begin{array}{l}\text { Augmented Dickey-Fuller test statistic } \\
\text { Test critical values: } \begin{array}{c}1 \% \text { level } \\
5 \% \text { level } \\
10 \% \text { level }\end{array} \\
\end{array}$} & $\begin{array}{l}-2.908276 \\
-4.156734 \\
-3.504330 \\
-3.181826\end{array}$ & 0.1689 & \multicolumn{3}{|c|}{$\begin{array}{lc}\text { Augmented Dickey-Fuller test statistic } \\
\text { Test critical values: } & 1 \% \text { level } \\
& 5 \% \text { level } \\
& 10 \% \text { level }\end{array}$} & $\begin{array}{l}-4.515204 \\
-4.161144 \\
-3.506374 \\
-3.183002\end{array}$ & 0.0038 \\
\hline \multicolumn{5}{|c|}{ *MacKinnon (1996) one-sided p-values. } & \multicolumn{5}{|c|}{ "MacKinnon (1996) one-sided p-values. } \\
\hline \multicolumn{5}{|c|}{$\begin{array}{l}\text { Augmented Dickey-Fuller Test Equation } \\
\text { Dependent Variable: D(IFN) } \\
\text { Method: Least Squares } \\
\text { Date: } 05 / 13 / 18 \text { Time: } 03: 12 \\
\text { Sample (adiusted): } 2005 \mathrm{Q} 42017 \mathrm{Q} 4 \\
\text { Included observations: } 49 \text { after adjustments }\end{array}$} & \multicolumn{5}{|c|}{$\begin{array}{l}\text { Augmented Dickey-Fuller Test Equation } \\
\text { Dependent Variable: D(IFN,2) } \\
\text { Method: Least Squares } \\
\text { Date: } 05 / 13 / 18 \text { time: } 03: 12 \\
\text { Sample (adjusted): } 2006 \mathrm{Q} 12017 \mathrm{Q} 4 \\
\text { Included observations: } 48 \text { after adjustments }\end{array}$} \\
\hline Variable & Coefficient & Std. Error & t-Statistic & Prob. & Variable & Coefficient & Std. Error & t-Statistic & Prob. \\
\hline $\begin{array}{c}\text { IFN(-1) } \\
\text { D(IFN (-1)) } \\
\text { D(IFN(-2)) } \\
\text { CTREN("2005Q1") } \\
\text { @TREND("2005 }\end{array}$ & $\begin{array}{r}-0.170993 \\
0.955349 \\
-0.348273 \\
0.025579 \\
-0.000420\end{array}$ & $\begin{array}{l}0.058795 \\
0.114361 \\
0.139180 \\
0.009975 \\
0.000219\end{array}$ & $\begin{array}{r}-2.908276 \\
8.353777 \\
-2.502320 \\
2.564294 \\
-1.918165\end{array}$ & $\begin{array}{l}0.0057 \\
0.0000 \\
0.0161 \\
0.0138 \\
0.0616\end{array}$ & $\begin{array}{c}\mathrm{D}(\mathrm{IFN}(-1)) \\
\mathrm{D}(\mathrm{IFN}(-1), 2) \\
\mathrm{D}(\mathrm{IFN}(-2), 2) \\
\text { @TREND("2005Q1") }\end{array}$ & $\begin{array}{r}-0.600577 \\
0.587805 \\
0.078808 \\
0.001062 \\
-6.96 \mathrm{E}-05\end{array}$ & $\begin{array}{l}0.133012 \\
0.122192 \\
0.152379 \\
0.006505 \\
0.000212\end{array}$ & $\begin{array}{r}-4.515204 \\
4.810512 \\
0.517185 \\
0.163308 \\
-0.329070\end{array}$ & $\begin{array}{l}0.0000 \\
0.0000 \\
0.6077 \\
0.8710 \\
0.7437\end{array}$ \\
\hline $\begin{array}{l}\text { R-squared } \\
\text { Adjusted R-squared } \\
\text { S.E. of regression } \\
\text { Sum squared resid } \\
\text { Log likelihood } \\
\text { F-statistic } \\
\text { Prob(F-statistic) }\end{array}$ & $\begin{array}{l}0.687389 \\
0.658970 \\
0.018415 \\
0.014921 \\
128.8445 \\
24.18748 \\
0.000000\end{array}$ & \multicolumn{2}{|c|}{$\begin{array}{l}\text { Mean dependent var } \\
\text { S.D. dependent var } \\
\text { Akaike info criterion } \\
\text { Schwarz criterion } \\
\text { Hannan-Quinn criter. } \\
\text { Durbin-Watson stat }\end{array}$} & $\begin{array}{r}-0.000984 \\
0.031533 \\
-5.054877 \\
-4.861835 \\
-4.981637 \\
1.940026\end{array}$ & $\begin{array}{l}\text { R-squared } \\
\text { Adjusted R-squared } \\
\text { S.E. of regression } \\
\text { Sum squared resid } \\
\text { Log likelihood } \\
\text { F-statistic } \\
\text { Prob(F-statistic) }\end{array}$ & $\begin{array}{l}0.468070 \\
0.418588 \\
0.020242 \\
0.017619 \\
121.7303 \\
9.459426 \\
0.000014\end{array}$ & \multicolumn{2}{|c|}{$\begin{array}{l}\text { Mean dependent var } \\
\text { S.D. dependent var } \\
\text { Akaike info criterion } \\
\text { Schwarz criterion } \\
\text { Hannan-Quinn criter. } \\
\text { Durbin-Watson stat }\end{array}$} & $\begin{array}{r}-0.000274 \\
0.026547 \\
-4.863760 \\
-4.668844 \\
-4.790101 \\
2.000086\end{array}$ \\
\hline
\end{tabular}

Fig.5: IFD - The Differential of Inflation between Vietnam and U.S.A

\begin{tabular}{|c|c|c|c|c|c|c|c|c|c|}
\hline \multicolumn{5}{|c|}{ Level } & \multicolumn{5}{|c|}{ First difference } \\
\hline \multicolumn{5}{|c|}{$\begin{array}{l}\text { Null Hypothesis: IFU has a unit root } \\
\text { Exogenous: Constant, Linear Trend } \\
\text { Lag Length: } 9 \text { (Automatic - based on SIC, maxlag=10) }\end{array}$} & \multicolumn{5}{|c|}{$\begin{array}{l}\text { Null Hypotnesıs: } U(I-U) \text { nas a unıt root } \\
\text { Exogenous: Constant, Linear Trend } \\
\text { Lag Length: } 7 \text { (Automatic - based on SIC, maxlag=10) }\end{array}$} \\
\hline & & & t-Statistic & Prob.* & & & & t-Statistic & Prob. ${ }^{*}$ \\
\hline \multicolumn{3}{|c|}{$\begin{array}{lc}\text { Augmented Dickey-Fuller test statistic } \\
\text { Test critical values: } & 1 \% \text { level } \\
& 5 \% \text { level } \\
& 10 \% \text { level } \\
\end{array}$} & $\begin{array}{l}-3.312281 \\
-4.192337 \\
-3.520787 \\
-3.191277 \\
\end{array}$ & 0.0782 & \multicolumn{3}{|c|}{$\begin{array}{lc}\text { Augmented Dickey-Fuller test statistic } \\
\text { Test critical values: } \quad 1 \% \text { level } \\
5 \% \text { level } \\
10 \% \text { level }\end{array}$} & $\begin{array}{l}-5.314526 \\
-4.186481 \\
-3.518090 \\
-3.189732\end{array}$ & 0.0004 \\
\hline \multicolumn{5}{|c|}{$\begin{array}{l}\text { Augmented Dickey-Fuller Test Equation } \\
\text { Dependent Variable: D(IFD) } \\
\text { Method: Least Squares } \\
\text { Date: } 05 / 13 / 18 \text { qime: } 03: 17 \\
\text { Sample (adjusted): } 2007 Q 32017 Q 4 \\
\text { Included observations: } 42 \text { after adjustments }\end{array}$} & \multicolumn{5}{|c|}{$\begin{array}{l}\text { *MacKinnon (1996) one-sided p-values. } \\
\\
\text { Augmented Dickey-Fuller Test Equation } \\
\text { Dependent Variable: D(IFD,2) } \\
\text { Method: Least Squares } \\
\text { Date: } 05 / 13 / 18 \text { ime: } 03: 18 \\
\text { Sample (adjusted): } 2007 \mathrm{Q} 22017 \mathrm{Q} 4 \\
\text { Included observations: } 43 \text { after adjustments }\end{array}$} \\
\hline Variable & Coefficient & Std. Error & t-Statistic & Prob. & Variable & Coefficient & Std. Error & t-Statistic & Prob. \\
\hline 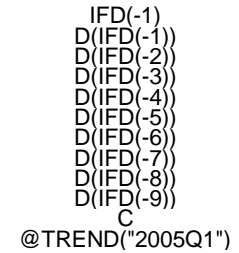 & $\begin{array}{r}-0.271033 \\
0.911518 \\
-0.197147 \\
0.367528 \\
-0.805543 \\
0.751766 \\
-0.219274 \\
0.187136 \\
-0.508478 \\
0.280714 \\
0.047512 \\
-0.000945\end{array}$ & $\begin{array}{l}0.081827 \\
0.151120 \\
0.193007 \\
0.186091 \\
0.187744 \\
0.213114 \\
0.190222 \\
0.181842 \\
0.166638 \\
0.142123 \\
0.013185 \\
0.000271\end{array}$ & $\begin{array}{r}-3.312281 \\
6.031742 \\
-1.021450 \\
1.974984 \\
-4.290639 \\
3.527534 \\
-1.152726 \\
1.029111 \\
-3.051387 \\
1.975153 \\
3.603563 \\
-3.482671\end{array}$ & $\begin{array}{l}0.0024 \\
0.0000 \\
0.3152 \\
0.0575 \\
0.0002 \\
0.0014 \\
0.2581 \\
0.3117 \\
0.0047 \\
0.0575 \\
0.0011 \\
0.0015\end{array}$ & 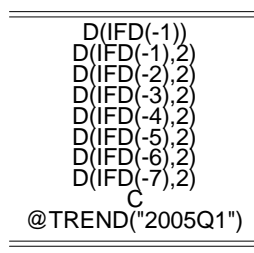 & $\begin{array}{r}-1.499605 \\
1.262682 \\
0.803021 \\
0.991648 \\
0.141086 \\
0.651152 \\
0.341210 \\
0.380693 \\
0.011565 \\
-0.000420\end{array}$ & $\begin{array}{l}0.282171 \\
0.230019 \\
0.241468 \\
0.231093 \\
0.177966 \\
0.160925 \\
0.145482 \\
0.150316 \\
0.006410 \\
0.000202\end{array}$ & $\begin{array}{r}-5.314526 \\
5.489476 \\
3.325581 \\
4.291122 \\
0.792768 \\
4.046311 \\
2.345374 \\
2.532614 \\
1.804039 \\
-2.082626\end{array}$ & $\begin{array}{l}0.0000 \\
0.0000 \\
0.0022 \\
0.0001 \\
0.4336 \\
0.0003 \\
0.0252 \\
0.0163 \\
0.0804 \\
0.0451\end{array}$ \\
\hline $\begin{array}{l}\text { R-squared } \\
\text { Adjusted R-squared } \\
\text { S.E. of regression } \\
\text { Sum squared resid } \\
\text { Log likelihood } \\
\text { F-statistic } \\
\text { Prob(F-statistic) }\end{array}$ & $\begin{array}{l}0.847811 \\
0.792009 \\
0.013154 \\
0.005191 \\
129.3739 \\
15.19304 \\
0.000000\end{array}$ & $\begin{array}{l}\text { Mean depe } \\
\text { S.D. depen } \\
\text { Akaike info } \\
\text { Schwarz cri } \\
\text { Hannan-Qu } \\
\text { Durbin-Wat }\end{array}$ & $\begin{array}{l}\text { dent var } \\
\text { dent var } \\
\text { criterion } \\
\text { terion } \\
\text { inn criter. } \\
\text { son stat }\end{array}$ & $\begin{array}{r}-0.000975 \\
0.028843 \\
-5.589235 \\
-5.092758 \\
-5.407256 \\
2.106560\end{array}$ & $\begin{array}{l}\text { R-squared } \\
\text { Adjusted R-squared } \\
\text { S.E. of regression } \\
\text { Sum squared resid } \\
\text { Log likelihood } \\
\text { F-statistic } \\
\text { Prnh(F-statistic) }\end{array}$ & $\begin{array}{l}0.685153 \\
0.599286 \\
0.015302 \\
0.007727 \\
124.4061 \\
7.979202 \\
\text { Oกกกกก4 }\end{array}$ & $\begin{array}{l}\text { Mean depen } \\
\text { S.D. depeno } \\
\text { Akaike info } \\
\text { Schwarz crit } \\
\text { Hannan-Qui } \\
\text { Durbin-Wats }\end{array}$ & $\begin{array}{l}\text { hdent var } \\
\text { dent var } \\
\text { criterion } \\
\text { terion } \\
\text { inn criter. } \\
\text { son stat }\end{array}$ & $\begin{array}{r}3.35 \mathrm{E}-05 \\
0.024173 \\
-5.321212 \\
-4.911630 \\
-5.170171 \\
1.780512\end{array}$ \\
\hline
\end{tabular}


Fig. 6: Unit root test of IT - Interest rate

\begin{tabular}{|c|c|c|c|c|c|c|c|c|c|}
\hline \multicolumn{5}{|c|}{ Level } & \multicolumn{5}{|c|}{ First difference } \\
\hline \multicolumn{5}{|c|}{$\begin{array}{l}\text { Null Hypothesis: II has a unit root } \\
\text { Exogenous: Constant, Linear Trend } \\
\text { Lag Length: } 1 \text { (Automatic - based on SIC, maxlag=10) }\end{array}$} & \multicolumn{5}{|c|}{$\begin{array}{l}\text { Null Hypothesis: } \mathrm{U}(\mathrm{II}) \text { has a unit root } \\
\text { Exogenous: Constant, Linear Trend } \\
\text { Lag Length: } 1 \text { (Automatic - based on SIC, maxlag=10) }\end{array}$} \\
\hline & & & t-Statistic & ${\text { Prob. }{ }^{*}}^{\prime}$ & & & & t-Statistic & Prob. $^{*}$ \\
\hline \multicolumn{3}{|c|}{$\begin{array}{cc}\text { Augmented Dickey-Fuller test statistic } \\
\text { Test critical values: } & 1 \% \% \text { level } \\
& 5 \% \text { level } \\
& 10 \% \text { level } \\
\end{array}$} & $\begin{array}{l}-2.988244 \\
-4.152511 \\
-3.502373 \\
-3.180699 \\
\end{array}$ & 0.1457 & \multicolumn{3}{|c|}{$\begin{array}{lc}\text { Augmented Dickey-Fuller test statistic } \\
\text { Test critical values: } & 1 \% \text { level } \\
& 5 \% \text { level } \\
& 10 \% \text { level } \\
\end{array}$} & $\begin{array}{l}-5.705681 \\
-4.156734 \\
-3.504330 \\
-3.181826\end{array}$ & 0.0001 \\
\hline \multicolumn{5}{|c|}{$\begin{array}{l}{ }^{*} \text { MacKinnon (1996) one-sided p-values. } \\
\\
\\
\text { Augmented Dickey-Fuller Test Equation } \\
\text { Dependent Variable: D(IT) } \\
\text { Method: Least Squares } \\
\text { Date: } 05 \text { Li/13/18 ime: } 03: 20 \\
\text { Sample (adjusted): } 2005032017 Q 4 \\
\text { Included observations: } 50 \text { after adjustments } \\
\end{array}$} & \multirow{2}{*}{\multicolumn{5}{|c|}{ 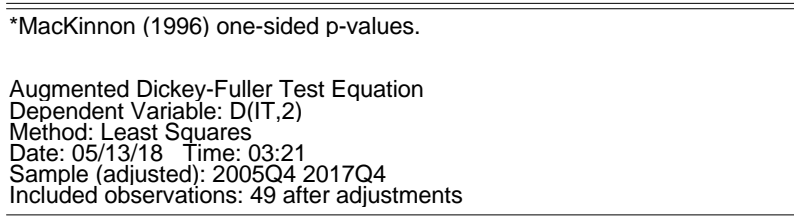 }} \\
\hline Variable & Coefficient & Std. Error & t-Statistic & Prob. & & & & & \\
\hline \multirow{2}{*}{$\begin{array}{c}\text { IT(-1) } \\
\text { D(IT(-1)) } \\
\text { @ } \\
\text { @TREND("2005Q1") } \\
\end{array}$} & \multirow{2}{*}{$\begin{array}{r}-0.215970 \\
0.411305 \\
1.931766 \\
-0.007388 \\
\end{array}$} & \multirow{2}{*}{$\begin{array}{l}0.072273 \\
0.132903 \\
0.704444 \\
0.013687 \\
\end{array}$} & \multirow{2}{*}{$\begin{array}{r}-2.988244 \\
3.094744 \\
2.742152 \\
-0.539764 \\
\end{array}$} & \multirow{2}{*}{$\begin{array}{l}0.0045 \\
0.0033 \\
0.0087 \\
0.5920 \\
\end{array}$} & \multirow{3}{*}{$\begin{array}{c}\text { Variable } \\
\mathrm{D}(\mathrm{IT}(-1)) \\
\mathrm{D}(\mathrm{IT}(-1), 2) \\
\mathrm{C} \\
\text { @TREND("2005Q1") }\end{array}$} & \multirow{3}{*}{$\begin{array}{c}\text { Coefficient } \\
-0.936104 \\
0.352361 \\
0.324236 \\
-0.011058\end{array}$} & \multirow{3}{*}{$\begin{array}{ll}\text { Std. Error } \\
0.164065 \\
0.139460 \\
0.445541 \\
0.014626 \\
\end{array}$} & \multirow{3}{*}{$\begin{array}{r}\text { t-Statistic } \\
-5.705681 \\
2.526603 \\
0.727736 \\
-0.756017\end{array}$} & \multirow{3}{*}{$\begin{array}{l}\text { Prob. } \\
0.0000 \\
0.0151 \\
0.4705 \\
0.4536\end{array}$} \\
\hline & & & & & & & & & \\
\hline \multirow{2}{*}{$\begin{array}{l}\text { R-squared } \\
\text { Adjusted R-squared } \\
\text { S.E. of regression } \\
\text { Sum squared resid } \\
\text { Log likelihood } \\
\text { F-statistic } \\
\text { Prob(F-statistic) }\end{array}$} & \multirow{2}{*}{$\begin{array}{l}0.250652 \\
0.201781 \\
1.388834 \\
88.72750 \\
-85.28560 \\
5.228896 \\
0.003824\end{array}$} & \multirow{2}{*}{\multicolumn{2}{|c|}{$\begin{array}{l}\text { Mean dependent var } \\
\text { S.D. dependent var } \\
\text { Akaike info criterion } \\
\text { Schwarz criterion } \\
\text { Hannan-Quinn criter. } \\
\text { Durbin-Watson stat }\end{array}$}} & $\begin{array}{l}0.025000 \\
1.554495\end{array}$ & & & & & \\
\hline & & & & $\begin{array}{l}3.571424 \\
3.724386 \\
3.629673 \\
1.813673\end{array}$ & $\begin{array}{l}\text { R-squared } \\
\text { Adjusted R-squared } \\
\text { S.E. of regression } \\
\text { Sum squared resid } \\
\text { Log likelihood } \\
\text { F-statistic } \\
\text { Prob(F-statistic) }\end{array}$ & $\begin{array}{l}0.427491 \\
0.389324 \\
1.435630 \\
92.74648 \\
-85.16020 \\
11.20045 \\
0.000013\end{array}$ & \multicolumn{2}{|c|}{$\begin{array}{l}\text { Mean dependent var } \\
\text { S.D. dependent var } \\
\text { Akaike info criterion } \\
\text { Schwarz criterion } \\
\text { Hannan-Quinn criter. } \\
\text { Durbin-Watson stat }\end{array}$} & $\begin{array}{l}0.000000 \\
1.837117 \\
3.639192 \\
3.793626 \\
3.697784 \\
1.969806\end{array}$ \\
\hline
\end{tabular}

Fig. 7: Unit root test of ITD - Differential of Interest rate between Vietnam and U.S.A

\begin{tabular}{|c|c|c|c|c|c|c|c|c|c|}
\hline \multicolumn{5}{|c|}{ Level } & \multicolumn{5}{|c|}{ First difference } \\
\hline \multicolumn{5}{|c|}{$\begin{array}{l}\text { Null Hypothesis: IIU nas a unit root } \\
\text { Exogenous: Constant, Linear Trend } \\
\text { Lag Length: } 1 \text { (Automatic - based on SIC, maxlag=10) }\end{array}$} & \multicolumn{5}{|c|}{$\begin{array}{l}\text { Null Hypothess: } \cup(I, U) \text { nas a unit root } \\
\text { Exogenous: Constant, Linear Trend } \\
\text { Lag Length: } 1 \text { (Automatic - based on SIC, maxlag=10) }\end{array}$} \\
\hline & & & $\mathrm{t}$-Statistic & Prob. $^{*}$ & & & & t-Statistic & Prob. ${ }^{*}$ \\
\hline \multicolumn{3}{|c|}{$\begin{array}{l}\text { Augmented Dickey-Fuller test statistic } \\
\text { Test critical values: } \\
\begin{array}{ll}1 \% \% \text { level } \\
5 \% \text { level } \\
10 \% \text { level }\end{array} \\
\end{array}$} & $\begin{array}{l}-2.384717 \\
-4.152511 \\
-3.502373 \\
-3.180699\end{array}$ & 0.3828 & \multicolumn{3}{|c|}{$\begin{array}{c}\text { Augmented Dickey-Fuller test statistic } \\
1 \% \% \text { level } \\
5 \% \text { level } \\
10 \% \text { level }\end{array}$} & $\begin{array}{l}-5.133267 \\
-4.156734 \\
-3.504330 \\
-3.181826\end{array}$ & 0.0006 \\
\hline \multicolumn{5}{|c|}{$\begin{array}{l}\text { Augmented Dickey-Fuller Test Equation } \\
\text { Dependent Variable: D(ITD) } \\
\text { Method: Least Squares } \\
\text { Date: 05/13/18 } \\
\text { Sample (adjusted): } 203: 23 \\
\text { Included observations: } 50 \text { after adjustments }\end{array}$} & \multicolumn{5}{|c|}{$\begin{array}{l}\text { Augmented Dickey-Fuller Test Equation } \\
\text { Dependent Variable: D (ITD,2) } \\
\text { Method: Least Squares } \\
\text { Date: } 05 / 13118 \text { Time: } 3: 24 \\
\text { Sample (adjusted): } 2005 \mathrm{Q} 42017 \mathrm{Q} 4 \\
\text { Included observations: } 49 \text { after adjustments }\end{array}$} \\
\hline Variable & Coefficient & Std. Error & t-Statistic & Prob. & Variable & Coefficient & Std. Error & t-Statistic & Prob. \\
\hline $\begin{array}{c}\operatorname{ITD}(-1) \\
\text { D(ITD(-1)) } \\
\mathrm{C}(-1) \\
\text { @TREND("2005Q1") }\end{array}$ & $\begin{array}{l}-0.126823 \\
0.496237 \\
0.829888 \\
0.001719\end{array}$ & $\begin{array}{l}0.053182 \\
0.128607 \\
0.457481 \\
0.014252\end{array}$ & $\begin{array}{l}-2.384717 \\
3.858568 \\
1.814036 \\
0.120631\end{array}$ & $\begin{array}{l}0.0213 \\
0.0004 \\
0.0762 \\
0.9045\end{array}$ & $\begin{array}{c}\mathrm{D}(\mathrm{ITD}(-1)) \\
\mathrm{D}(\mathrm{ITD}(-1), 2) \\
\text { @TREND("2005Q1") }\end{array}$ & $\begin{array}{r}-0.768299 \\
0.332867 \\
0.436623 \\
-0.014095\end{array}$ & $\begin{array}{l}0.149671 \\
0.139715 \\
0.424392 \\
0.013914\end{array}$ & $\begin{array}{r}-5.133267 \\
2.382472 \\
1.028818 \\
-1.013004\end{array}$ & $\begin{array}{l}0.0000 \\
0.0215 \\
0.3091 \\
0.3165\end{array}$ \\
\hline $\begin{array}{l}\text { R-squared } \\
\text { Adiusted R-squared } \\
\text { S.E. of regression } \\
\text { Sum squared resid } \\
\text { Log likelihood } \\
\text { F-statistic } \\
\text { Prob(F-statistic) }\end{array}$ & $\begin{array}{l}0.290474 \\
0.244200 \\
1.347541 \\
83.52999 \\
-83.77646 \\
6.277325 \\
0.001161\end{array}$ & \multicolumn{2}{|c|}{$\begin{array}{l}\text { Mean dependent var } \\
\text { S.D. dependent var } \\
\text { Akaike info criterion } \\
\text { Schwarz criterion } \\
\text { Hannan- Quinn criter. } \\
\text { Durbin-Waitson stat }\end{array}$} & $\begin{array}{l}0.060000 \\
1.550025 \\
3.511059 \\
3.664020 \\
3.569307 \\
1.767538\end{array}$ & $\begin{array}{l}\text { R-squared } \\
\text { Adiusted R-squared } \\
\text { S.E. of regression } \\
\text { Sum squared resid } \\
\text { Log likelihood } \\
\text { F-statistic } \\
\text { Prob(F-statistic) }\end{array}$ & $\begin{array}{l}0.371042 \\
0.329111 \\
1.358281 \\
83.02167 \\
-82.44638 \\
8.848965 \\
0.000101\end{array}$ & \multicolumn{2}{|c|}{$\begin{array}{l}\text { Mean dependent var } \\
\text { S.D. dependent var } \\
\text { Akaike info criterion } \\
\text { Schwarz criterion } \\
\text { Hannan-Quinn criter. } \\
\text { Durbin-Watson stat }\end{array}$} & $\begin{array}{l}0.005102 \\
1.658304 \\
3.528424 \\
3.682858 \\
3.587016 \\
1.992080\end{array}$ \\
\hline
\end{tabular}


Fig. 8: Unit root test of Logarithm of exchange rate

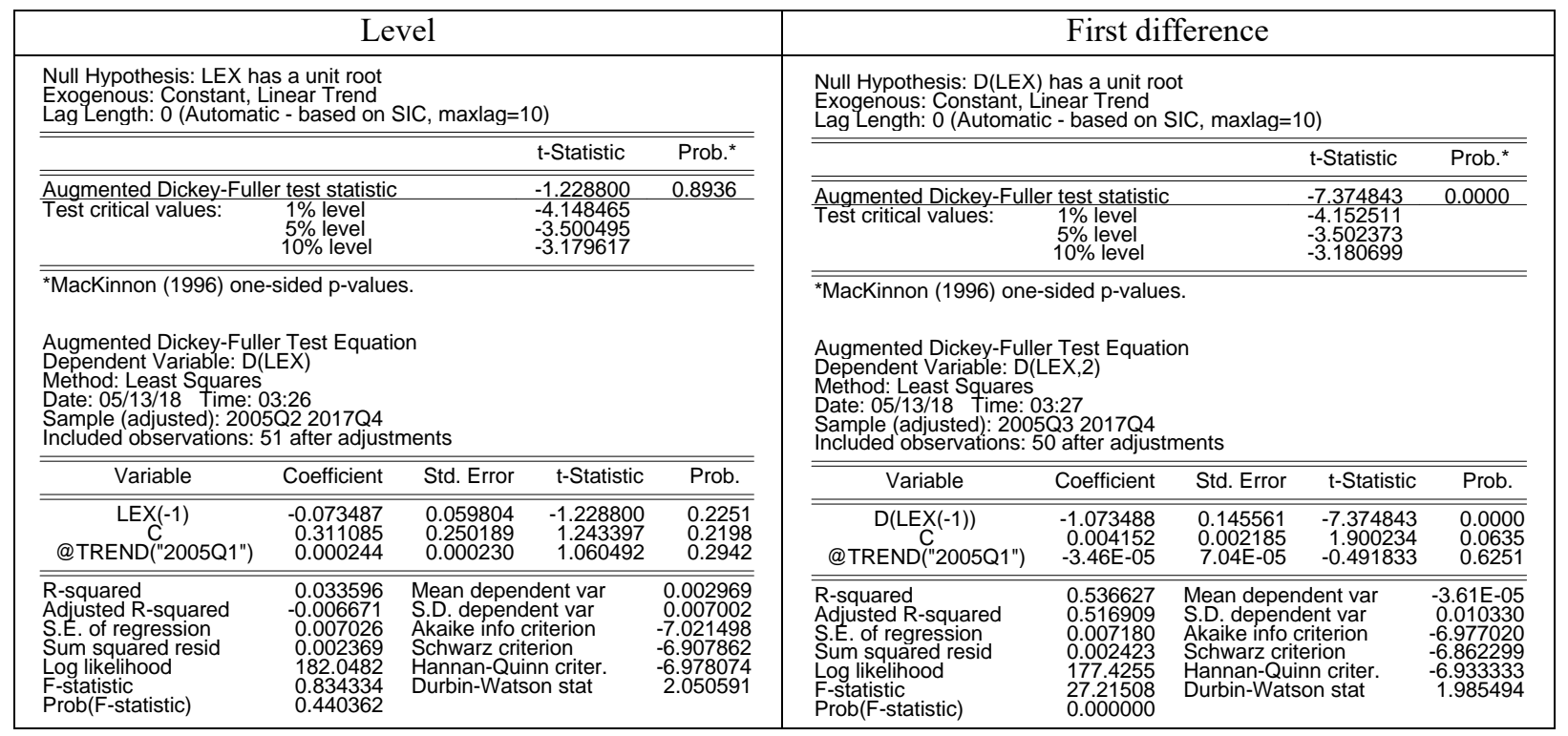

Fig. 9: Unit root test of Logarithm of Reserves

\begin{tabular}{|c|c|c|c|c|c|c|c|c|c|}
\hline \multicolumn{5}{|c|}{ Level } & \multicolumn{5}{|c|}{ First difference } \\
\hline \multicolumn{5}{|c|}{$\begin{array}{l}\text { Null Hypothesis: LK has a unit root } \\
\text { Exogenous: Constant, Linear Trend } \\
\text { Lag Length: } 0 \text { (Automatic - based on SIC, maxlag=10) }\end{array}$} & \multicolumn{5}{|c|}{$\begin{array}{l}\text { Null Hypothesis: D(LR) has a unit root } \\
\text { Exogenous: Constant, Linear Trend } \\
\text { Lag Length: } 0 \text { (Automatic - based on SIC, maxlag=10) }\end{array}$} \\
\hline & & & t-Statistic & Prob. ${ }^{*}$ & & & & t-Statistic & Prob.* \\
\hline \multicolumn{3}{|c|}{$\begin{array}{cc}\text { Augmented Dickey-Fuller test statistic } \\
\text { Test critical values: } & 1 \% \% \text { level } \\
& 5 \% \text { level } \\
& 10 \% \text { level }\end{array}$} & $\begin{array}{l}-1.119612 \\
-4.148465 \\
-3.500495 \\
-3.179617\end{array}$ & 0.9155 & \multicolumn{3}{|c|}{$\begin{array}{lc}\text { Augmented Dickey-Fuller test statistic } \\
\text { Test critical values: } & 1 \% \text { level } \\
& 5 \% \text { level } \\
& 10 \% \text { level } \\
\end{array}$} & $\begin{array}{l}-5.007874 \\
-4.152511 \\
-3.502373 \\
-3.180699\end{array}$ & 0.0009 \\
\hline \multicolumn{5}{|c|}{ 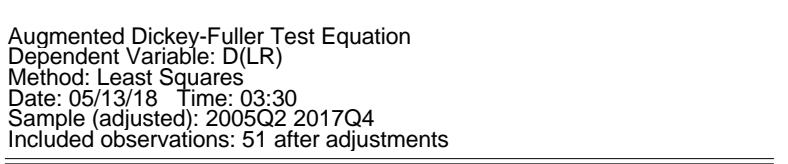 } & \multicolumn{5}{|c|}{$\begin{array}{l}\text { Augmented Dickey-Fuller Test Equation } \\
\text { Dependent Variable: D(LR,2) } \\
\text { Method: Least Squares } \\
\text { Date: } 05 \text { Les } 1318 \text { ime: } 03: 31 \\
\text { Sample (adjusted): } 200503201704 \\
\text { Included observations: } 50 \text { after adjustments } \\
\end{array}$} \\
\hline Variable & Coefficient & Std. Error & t-Statistic & Prob. & Variable & $\begin{array}{l}\text { Coefficient } \\
\end{array}$ & Std. Error & t-Statistic & Prob. \\
\hline $\begin{array}{c}\text { LR(-1) } \\
C \\
\text { @TREND("2005Q1") }\end{array}$ & $\begin{array}{r}-0.079438 \\
0.875513 \\
0.066582\end{array}$ & $\begin{array}{l}0.070952 \\
0.991693 \\
0.046150\end{array}$ & $\begin{array}{l}-1.119612 \\
0.882847 \\
1.442740\end{array}$ & $\begin{array}{l}0.2685 \\
0.3817 \\
0.1556\end{array}$ & $\begin{array}{c}\mathrm{D}(\mathrm{LR}(-1)) \\
\mathrm{C}(" 2005 \mathrm{Q} 1 ") \\
\text { @TREND( }\end{array}$ & $\begin{array}{l}-0.757562 \\
0.096047 \\
0.021142 \\
\end{array}$ & $\begin{array}{l}0.151274 \\
0.804722 \\
0.026607 \\
\end{array}$ & $\begin{array}{l}-5.007874 \\
0.119355 \\
0.794580 \\
\end{array}$ & $\begin{array}{l}0.0000 \\
0.9055 \\
0.4309 \\
\end{array}$ \\
\hline $\begin{array}{l}\text { R-squared } \\
\text { Adiusted R-squared } \\
\text { S.E. of regression } \\
\text { Sum squared resid } \\
\text { Log likelihood } \\
\text { F-statistic } \\
\text { Prob(F-statistic) }\end{array}$ & $\begin{aligned} 0.041903 \\
0.001982 \\
2.720937 \\
355.3678 \\
-121.8697 \\
1.049649 \\
0.357957\end{aligned}$ & \multicolumn{2}{|c|}{$\begin{array}{l}\text { Mean dependent var } \\
\text { S.D. dependent var } \\
\text { Akaike inf criterion } \\
\text { Schwarz criterion } \\
\text { Hannan- Quinn criter. } \\
\text { Durbin-Watson stat }\end{array}$} & $\begin{array}{l}0.799402 \\
2.723637 \\
4.896852 \\
5.010489 \\
4.940276 \\
1.398496\end{array}$ & $\begin{array}{l}\text { R-squared } \\
\text { Adjusted R-squared } \\
\text { S.E. of regression } \\
\text { Sum squared resid } \\
\text { Log likelihood } \\
\text { F-statistic } \\
\text { Prob(F-statistic) }\end{array}$ & $\begin{array}{r}0.350742 \\
0.323114 \\
2.712001 \\
345.6825 \\
-119.2844 \\
12.69518 \\
0.000039\end{array}$ & \multicolumn{2}{|c|}{$\begin{array}{l}\text { Mean dependent var } \\
\text { S.D. dependent var } \\
\text { Akaike info criterion } \\
\text { Schwarz criterion } \\
\text { Hannan--Quinn criter. } \\
\text { Durbin-Watson stat }\end{array}$} & $\begin{array}{l}0.155485 \\
3.296341 \\
4.891375 \\
5.006096 \\
4.935061 \\
1.829033\end{array}$ \\
\hline
\end{tabular}




\section{Lag length criteria:}

Fig. 10: Lag Length Criteria of Group 1

VAK Lag Urder Selectıon Criteria

Endogenous variables: D(LEX) D(BOP) D(GDP) D(IFD) D(ITD)

Exogenous variables: $C$

Date: 05/13/18 Time: 03:36

Sample: 2005Q1 2017Q4

Included observations: 47

\begin{tabular}{ccccccc}
\hline \hline Lag & LogL & LR & FPE & AIC & SC & HQ \\
\hline \hline 0 & 40.16338 & NA & $1.54 \mathrm{e}-07$ & -1.496314 & $-1.299490^{*}$ & -1.422248 \\
1 & 78.85985 & 67.51300 & $8.66 \mathrm{e}-08$ & -2.079143 & -0.898197 & -1.634745 \\
2 & 110.8121 & 48.94810 & $6.69 \mathrm{e}-08$ & -2.374982 & -0.209916 & -1.560253 \\
3 & 140.1429 & 38.69176 & $6.13 \mathrm{e}-08$ & -2.559274 & 0.589914 & -1.374213 \\
4 & 194.5926 & $60.24220^{*}$ & $2.13 \mathrm{e}-08^{*}$ & $-3.812452^{*}$ & 0.320857 & $-2.257060^{*}$ \\
\hline
\end{tabular}

* indicates lag order selected by the criterion

LR: sequential modified LR test statistic (each test at 5\% level)

FPE: Final prediction error

AIC: Akaike information criterion

SC: Schwarz information criterion

$\mathrm{HQ}$ : Hannan-Quinn information criterion

Fig. 11: Lag Length Criteria of Group 2

VAK Lag Urder Selection Uriteria

Endogenous variables: D(LEX) D(BOP) D(GDP) D(IFN) D(IT) D(LR)

Exogenous variables: $C$

Date: 05/13/18 Time: 03:34

Sample: 2005Q1 2017Q4

Included observations: 47

\begin{tabular}{ccccccc}
\hline \hline Lag & LogL & LR & FPE & AIC & SC & HQ \\
\hline \hline 0 & -79.55129 & NA & $1.54 \mathrm{e}-06$ & 3.640480 & $3.876669^{*}$ & 3.729360 \\
1 & -29.72263 & 84.81474 & $8.64 \mathrm{e}-07$ & 3.052027 & 4.705350 & $3.674184^{\star}$ \\
2 & 12.22004 & 60.68301 & $7.23 \mathrm{e}-07$ & 2.799147 & 5.869605 & 3.954581 \\
3 & 44.34578 & 38.27748 & $1.05 \mathrm{e}-06$ & 2.964009 & 7.451601 & 4.652720 \\
4 & 115.5602 & $66.66882^{*}$ & $3.62 \mathrm{e}-07^{*}$ & $1.465523^{*}$ & 7.370250 & 3.687512 \\
\hline
\end{tabular}

* indicates lag order selected by the criterion

LR: sequential modified LR test statistic (each test at 5\% level)

FPE: Final prediction error

AIC: Akaike information criterion

SC: Schwarz information criterion

HQ: Hannan-Quinn information criterion 


\section{Johansen Cointegration Test:}

Fig. 1: Johansen Cointegration Test of Group 1

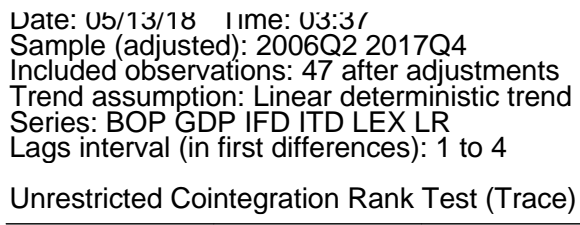

\begin{tabular}{ccccc}
\hline \hline $\begin{array}{c}\text { Hypothesized } \\
\text { No. of CE(s) }\end{array}$ & Eigenvalue & $\begin{array}{c}\text { Trace } \\
\text { Statistic }\end{array}$ & $\begin{array}{c}0.05 \\
\text { Critical Value }\end{array}$ & Prob. $^{* *}$ \\
\hline \hline None * & 0.789753 & 174.5419 & 95.75366 & 0.0000 \\
At most 1 * & 0.589330 & 101.2467 & 69.81889 & 0.0000 \\
At most 2 * & 0.380742 & 59.41832 & 47.85613 & 0.0029 \\
At most 3 & 0.374041 & 36.89434 & 29.79707 & 0.0064 \\
At most 4 & 0.269176 & 14.87622 & 15.49471 & 0.0618 \\
At most 5 & 0.002929 & 0.137844 & 3.841466 & 0.7104 \\
\hline
\end{tabular}

Trace test indicates 4 cointegrating eqn(s) at the 0.05 level

* denotes rejection of the hypothesis at the 0.05 level

${ }^{* *}$ MacKinnon-Haug-Michelis (1999) p-values

Unrestricted Cointegration Rank Test (Maximum Eigenvalue)

\begin{tabular}{ccccc}
\hline \hline $\begin{array}{c}\text { Hypothesized } \\
\text { No. of CE(s) }\end{array}$ & Eigenvalue & $\begin{array}{c}\text { Max-Eigen } \\
\text { Statistic }\end{array}$ & $\begin{array}{c}0.05 \\
\text { Critical Value }\end{array}$ & Prob. $^{* *}$ \\
\hline \hline None * & 0.789753 & 73.29524 & 40.07757 & 0.0000 \\
At most 1 $^{*}$ & 0.589330 & 41.82838 & 33.87687 & 0.0046 \\
At most 2 & 0.380742 & 22.52397 & 27.58434 & 0.1947 \\
At most 3 & 0.374041 & 22.01812 & 21.13162 & 0.0375 \\
At most 4 & 0.269176 & 14.73838 & 14.26460 & 0.0420 \\
At most 5 & 0.002929 & 0.137844 & 3.841466 & 0.7104 \\
\hline \hline
\end{tabular}

Max-eigenvalue test indicates 2 cointegrating eqn(s) at the 0.05 level

* denotes rejection of the hypothesis at the 0.05 level

**MacKinnon-Haug-Michelis (1999) p-values

Fig. 13: Johansen Cointegration Test of Group 2

Date: $05 / 11 / 18$ Time: $11: 13$

Sample (adjusted): 2006Q2 2017Q4

Included observations: 47 after adjustments

Trend assumption: Linear deterministic trend

Series: BOP GDP IFN IT LEX LR

Lags interval (in first differences): 1 to 4

Unrestricted Cointegration Rank Test (Trace)

\begin{tabular}{ccccc}
\hline \hline $\begin{array}{c}\text { Hypothesized } \\
\text { No. of CE(s) }\end{array}$ & Eigenvalue & $\begin{array}{c}\text { Trace } \\
\text { Statistic }\end{array}$ & $\begin{array}{c}0.05 \\
\text { Critical Value }\end{array}$ & Prob. $^{* *}$ \\
\hline \hline None * & 0.778199 & 180.1153 & 95.75366 & 0.0000 \\
At most 1 * & 0.604719 & 109.3344 & 69.81889 & 0.0000 \\
At most 2 * & 0.453941 & 65.71096 & 47.85613 & 0.0005 \\
At most 3 * & 0.377004 & 37.27466 & 29.79707 & 0.0057 \\
At most 4 & 0.267144 & 15.03353 & 15.49471 & 0.0586 \\
At most 5 & 0.009016 & 0.425657 & 3.841466 & 0.5141 \\
\hline \hline
\end{tabular}

Trace test indicates 4 cointegrating eqn(s) at the 0.05 level

* denotes rejection of the hypothesis at the 0.05 level

**MacKinnon-Haug-Michelis (1999) p-values

Unrestricted Cointegration Rank Test (Maximum Eigenvalue)

\begin{tabular}{ccccc}
\hline \hline $\begin{array}{c}\text { Hypothesized } \\
\text { No. of CE(s) }\end{array}$ & Eigenvalue & $\begin{array}{c}\text { Max-Eigen } \\
\text { Statistic }\end{array}$ & $\begin{array}{c}0.05 \\
\text { Critical Value }\end{array}$ & Prob. * $^{*}$ \\
\hline \hline None * $^{*}$ & 0.778199 & 70.78089 & 40.07757 & 0.0000 \\
At most 1 * & 0.604719 & 43.62340 & 33.87687 & 0.0025 \\
At most 2 * & 0.453941 & 28.43631 & 27.58434 & 0.0388 \\
At most 3 * & 0.377004 & 22.24112 & 21.13162 & 0.0348 \\
At most 4 * & 0.267144 & 14.60787 & 14.26460 & 0.0441 \\
At most 5 & 0.009016 & 0.425657 & 3.841466 & 0.5141 \\
\hline \hline
\end{tabular}

Max-eigenvalue test indicates 5 cointegrating eqn(s) at the 0.05 leve

* denotes rejection of the hypothesis at the 0.05 level

**MacKinnon-Haug-Michelis (1999) p-values 


\section{Vector Error Correction Estimates}

Fig. 2: VEC Estimates of Group 1:

\begin{tabular}{|c|c|c|c|c|c|c|}
\hline Cointegrating Eq: & CointEq1 & CointEq2 & CointEq3 & CointEq4 & & \\
\hline LEX(-1) & 1.000000 & 0.000000 & 0.000000 & 0.000000 & & \\
\hline $\mathrm{BOP}(-1)$ & 0.000000 & 1.000000 & 0.000000 & 0.000000 & & \\
\hline $\operatorname{GDP}(-1)$ & 0.000000 & 0.000000 & 1.000000 & 0.000000 & & \\
\hline $\operatorname{IFD}(-1)$ & 0.000000 & 0.000000 & 0.000000 & 1.000000 & & \\
\hline ITD(-1) & $\begin{array}{r}-0.006808 \\
(0.00202) \\
{[-3.37527]}\end{array}$ & $\begin{array}{r}-0.168333 \\
(0.08142) \\
{[-2.06747]}\end{array}$ & $\begin{array}{r}0.299087 \\
(0.03467) \\
\lceil 8.62674\rceil\end{array}$ & $\begin{array}{r}-0.007290 \\
(0.00187) \\
{[-3.90649]}\end{array}$ & & \\
\hline $\operatorname{LR}(-1)$ & $\begin{array}{r}-0.004258 \\
(0.00069) \\
{[-6.20511]}\end{array}$ & $\begin{array}{r}-0.059765 \\
(0.02770) \\
{[-2.15739]}\end{array}$ & $\left.\begin{array}{r}0.011484 \\
(0.01180 \\
{[0.97352}\end{array}\right]$ & $\begin{array}{r}0.002233 \\
(0.00063) \\
{[3.51643]}\end{array}$ & & \\
\hline C & -4.136319 & 2.386273 & -8.641922 & -0.069433 & & \\
\hline Error Correction: & $\mathrm{D}(\mathrm{LEX})$ & $\mathrm{D}(\mathrm{BOP})$ & $\mathrm{D}(\mathrm{GDP})$ & $\mathrm{D}(\mathrm{IFD})$ & $\mathrm{D}(\mathrm{ITD})$ & $\mathrm{D}(\mathrm{LR})$ \\
\hline CointEq1 & $\begin{array}{r}0.096583 \\
(0.17130) \\
{[0.56382]}\end{array}$ & $\begin{array}{r}107.9254 \\
(37.1216) \\
\lceil 2.90735]\end{array}$ & $\begin{array}{r}0.143011 \\
(13.4969) \\
{[0.01060]}\end{array}$ & $\begin{array}{r}-0.858434 \\
(0.62314) \\
{[-1.37759]}\end{array}$ & $\begin{array}{r}-36.61285 \\
(42.7915) \\
{[-0.85561]}\end{array}$ & $\begin{array}{r}173.5104 \\
\mid(74.4355 \\
|2.33102|\end{array}$ \\
\hline CointEq2 & $\begin{array}{r}-0.005088 \\
(0.00286) \\
{[-1.78103]}\end{array}$ & $\begin{array}{r}-1.773800 \\
(0.61906) \\
{[-2.86529]}\end{array}$ & $\begin{array}{r}0.014074 \\
(0.22508 \\
{[0.06253]}\end{array}$ & $\begin{array}{r}0.005884 \\
(0.01039) \\
{[0.56620]}\end{array}$ & $\begin{array}{r}0.249833 \\
(0.71362) \\
{[0.35009]}\end{array}$ & $\begin{array}{r}-1.541122 \\
(1.24134) \\
{[-1.24150]}\end{array}$ \\
\hline CointEq3 & $\begin{array}{r}-0.000713 \\
(0.00347) \\
{[-0.20574]}\end{array}$ & $\begin{array}{r}-1.985898 \\
(0.75095) \\
{[-2.64452]}\end{array}$ & $\begin{array}{r}-0.793073 \\
(0.27304 \\
{[-2.90464]}\end{array}$ & $\begin{array}{r}0.019948 \\
(0.01261 \\
{[1.58242]}\end{array}$ & $\begin{array}{r}1.045950 \\
(0.86565) \\
{[1.20828]}\end{array}$ & $\begin{array}{r}-2.497797 \\
(1.50579) \\
{[-1.65879]}\end{array}$ \\
\hline CointEq4 & $\begin{array}{r}0.074109 \\
(0.15053) \\
{[0.49233}\end{array}$ & $\begin{array}{r}40.39197 \\
(32.6194) \\
{[1.23828]}\end{array}$ & $\begin{array}{r}-3.331681 \\
(11.8600) \\
{[-0.28092]}\end{array}$ & $\begin{array}{r}-0.741392 \\
(0.54756) \\
{[-1.35398]}\end{array}$ & $\begin{array}{r}-10.59312 \\
(37.6017) \\
{[-0.28172]}\end{array}$ & $\begin{array}{r}88.96326 \\
(65.4078 \\
{[1.36013}\end{array}$ \\
\hline $\mathrm{D}(\operatorname{LEX}(-1))$ & $\begin{array}{c}-0.608682 \\
(0.27099) \\
{[-2.24618]}\end{array}$ & $\begin{array}{r}-66.02946 \\
(58.7232) \\
{[-1.12442]}\end{array}$ & $\begin{array}{r}6.841190 \\
(21.3510) \\
{[0.32041]}\end{array}$ & $\begin{array}{r}1.469619 \\
(0.98576) \\
{[1.49085]}\end{array}$ & $\begin{array}{r}20.74851 \\
(67.6926) \\
{[0.30651]}\end{array}$ & $\begin{array}{r}-129.8675 \\
(117.751) \\
{[-1.10290]}\end{array}$ \\
\hline $\mathrm{D}(\operatorname{LEX}(-2))$ & $\begin{array}{r}-0.116698 \\
(0.25340) \\
{[-0.46054]}\end{array}$ & $\begin{array}{r}-186.0416 \\
(54.9116) \\
{[-3.38802]}\end{array}$ & $\begin{array}{r}17.20751 \\
(19.9652) \\
{[0.86188]}\end{array}$ & $\begin{array}{r}0.866070 \\
(0.92177) \\
{[0.93957]}\end{array}$ & $\begin{array}{r}33.57358 \\
(63.2988) \\
{[0.53040]}\end{array}$ & $\begin{array}{r}-240.8729 \\
(110.108) \\
{[-2.18761]}\end{array}$ \\
\hline $\mathrm{D}(\operatorname{LEX}(-3))$ & $\begin{array}{r}-0.282424 \\
(0.32061) \\
{[-0.88089]}\end{array}$ & $\begin{array}{r}-156.2236 \\
(69.4775) \\
{[-2.24855]}\end{array}$ & $\begin{array}{r}30.01023 \\
(25.2612) \\
{[1.18800]}\end{array}$ & $\begin{array}{r}0.836090 \\
(1.16628) \\
{[0.71688}\end{array}$ & $\begin{array}{r}89.32861 \\
(80.0895) \\
{[1.11536]}\end{array}$ & $\begin{array}{r}-302.5211 \\
(139.315) \\
{[-2.17149]}\end{array}$ \\
\hline $\mathrm{D}(\operatorname{LEX}(-4))$ & $\begin{array}{r}-0.169869 \\
(0.29080) \\
{[-0.58414]}\end{array}$ & $\begin{array}{r}2.485311 \\
(63.0171) \\
\lceil 0.03944\rceil\end{array}$ & $\begin{array}{r}27.19247 \\
(22.9122) \\
\lceil 1.18681]\end{array}$ & $\begin{array}{r}0.321702 \\
(1.05784) \\
\lceil 0.30411\rceil\end{array}$ & $\begin{array}{r}35.02880 \\
(72.6423) \\
\lceil 0.48221]\end{array}$ & $\begin{array}{r}-151.2485 \\
(126.361) \\
{[-1.19696}\end{array}$ \\
\hline $\mathrm{D}(\mathrm{BOP}(-1))$ & $\begin{array}{r}0.003946 \\
(0.00218) \\
{[1.80670]}\end{array}$ & $\begin{array}{r}0.928780 \\
(0.47333) \\
{[1.96223]}\end{array}$ & $\begin{array}{r}0.026849 \\
(0.17210) \\
{[0.15601]}\end{array}$ & $\begin{array}{r}-0.007617 \\
(0.00795) \\
{[-0.95864]}\end{array}$ & $\begin{array}{r}-0.480303 \\
(0.54563) \\
{[-0.88028]}\end{array}$ & $\begin{array}{r}1.330579 \\
\text { (0.94911) } \\
\text { [1.40192 }\end{array}$ \\
\hline $\mathrm{D}(\mathrm{BOP}(-2))$ & $\begin{array}{r}0.002697 \\
(0.00204) \\
{[1.31993]}\end{array}$ & $\begin{array}{r}0.768108 \\
(0.44278) \\
{[1.73474]}\end{array}$ & $\begin{array}{r}-0.097367 \\
(0.16099) \\
{[-0.60481]}\end{array}$ & $\begin{array}{r}-0.007554 \\
(0.00743) \\
{[-1.01634]}\end{array}$ & $\begin{array}{r}-0.506451 \\
(0.51041) \\
{[-0.99224]}\end{array}$ & $\begin{array}{r}1.986351 \\
\text { [0.88785 } \\
{[2.23725]}\end{array}$ \\
\hline $\mathrm{D}(\mathrm{BOP}(-3))$ & $\begin{array}{r}0.004108 \\
(0.00173) \\
{[2.37556]}\end{array}$ & $\begin{array}{r}0.131842 \\
(0.37477) \\
{[0.35180]}\end{array}$ & $\begin{array}{r}-0.066306 \\
(0.13626) \\
{[-0.48661]}\end{array}$ & $\begin{array}{r}-0.006121 \\
(0.00629) \\
{[-0.97302]}\end{array}$ & $\begin{array}{r}-0.352195 \\
(0.43201) \\
{[-0.81525]}\end{array}$ & $\begin{array}{r}0.858893 \\
(0.75148) \\
\lceil 1.14294 \mid\end{array}$ \\
\hline $\mathrm{D}(\mathrm{BOP}(-4))$ & $\begin{array}{r}0.003321 \\
(0.00107) \\
{[3.11416]}\end{array}$ & $\begin{array}{r}-0.285090 \\
(0.23106) \\
{[-1.23383]}\end{array}$ & $\begin{array}{r}0.031353 \\
(0.08401) \\
{[0.37320]}\end{array}$ & $\begin{array}{r}-0.002551 \\
(0.00388) \\
{[-0.65764]}\end{array}$ & $\begin{array}{r}-0.105899 \\
(0.26635) \\
{[-0.39759]}\end{array}$ & $\begin{array}{r}-0.353587 \\
(0.46332) \\
{[-0.76316]}\end{array}$ \\
\hline
\end{tabular}




\begin{tabular}{|c|c|c|c|c|c|c|}
\hline $\mathrm{D}(\mathrm{GDP}(-1))$ & $\begin{array}{r}0.002755 \\
(0.00316) \\
{[0.87205]}\end{array}$ & $\begin{array}{r}1.145300 \\
(0.68473) \\
{[1.67262]}\end{array}$ & $\begin{array}{r}0.276181 \\
(0.24896) \\
{[1.10934]}\end{array}$ & $\begin{array}{r}-0.013962 \\
(0.01149) \\
{[-1.21467]}\end{array}$ & $\begin{array}{r}-0.579343 \\
(0.78932) \\
{[-0.73398]}\end{array}$ & $\begin{array}{r}2.943078 \\
(1.37301) \\
{[2.14352]}\end{array}$ \\
\hline $\mathrm{D}(\mathrm{GDP}(-2))$ & $\begin{array}{r}0.004167 \\
(0.00261 \\
{[1.59960]}\end{array}$ & $\begin{array}{r}-0.408342 \\
(0.56456) \\
{[-0.72329]}\end{array}$ & $\begin{array}{r}0.001981 \\
(0.20527 \\
{[0.00965]}\end{array}$ & $\begin{array}{c}-0.009757 \\
(0.00948) \\
{[-1.02952]}\end{array}$ & $\begin{array}{r}0.073720 \\
(0.65079) \\
{[0.11328]}\end{array}$ & $\begin{array}{r}1.474739 \\
(1.13205) \\
{[1.30272]}\end{array}$ \\
\hline $\mathrm{D}(\mathrm{GDP}(-3))$ & $\begin{array}{r}0.003418 \\
(0.00206) \\
{[1.66097]}\end{array}$ & $\begin{array}{r}0.272865 \\
(0.44589) \\
{[0.61196]}\end{array}$ & $\begin{array}{r}-0.047545 \\
(0.16212) \\
{[-0.29327]}\end{array}$ & $\begin{array}{r}-0.007293 \\
(0.00748) \\
{[-0.97437]}\end{array}$ & $\begin{array}{r}0.149958 \\
(0.51399) \\
{[0.29175]}\end{array}$ & $\begin{array}{r}0.674461 \\
(0.89409) \\
{[0.75436]}\end{array}$ \\
\hline $\mathrm{D}(\mathrm{GDP}(-4))$ & $\begin{array}{r}0.001119 \\
(0.00218) \\
{[0.51352]}\end{array}$ & $\begin{array}{r}-0.311234 \\
(0.47237) \\
{[-0.65888]}\end{array}$ & $\begin{array}{r}0.487133 \\
(0.17175) \\
\lceil 2.83631]\end{array}$ & $\begin{array}{r}-0.002542 \\
(0.00793) \\
{[-0.32063]}\end{array}$ & $\begin{array}{r}0.110363 \\
(0.54452) \\
{[0.20268]}\end{array}$ & $\begin{array}{r}0.198880 \\
(0.94719) \\
{[0.20997\rceil}\end{array}$ \\
\hline $\mathrm{D}(\mathrm{IFD}(-1))$ & $\begin{array}{r}-0.049589 \\
(0.12438) \\
{[-0.39870]}\end{array}$ & $\begin{array}{r}18.18003 \\
(26.9525) \\
\lceil 0.67452\rceil\end{array}$ & $\begin{array}{r}-9.312341 \\
(9.79960) \\
{[-0.95028 \mid}\end{array}$ & $\begin{array}{r}0.817150 \\
(0.45244) \\
{[1.80610]}\end{array}$ & $\begin{array}{r}40.08665 \\
(31.0692) \\
\lceil 1.29024 \mid\end{array}$ & $\begin{array}{r}-69.83898 \\
(54.0447) \\
{[-1.29225]}\end{array}$ \\
\hline $\mathrm{D}(\mathrm{IFD}(-2))$ & $\begin{array}{r}0.015114 \\
(0.10776) \\
\lceil 0.14025]\end{array}$ & $\begin{array}{r}-44.20356 \\
(23.3523) \\
{[-1.89290]}\end{array}$ & $\begin{array}{r}-1.010957 \\
(8.49063) \\
{[-0.11907]}\end{array}$ & $\begin{array}{r}0.252004 \\
(0.39200) \\
{[0.64286]}\end{array}$ & $\begin{array}{r}3.936534 \\
(26.9192) \\
\mid 0.14624]\end{array}$ & $\begin{array}{r}-25.64258 \\
(46.8257) \\
{[-0.54762]}\end{array}$ \\
\hline $\mathrm{D}(\operatorname{IFD}(-3))$ & $\begin{array}{r}-0.030788 \\
(0.11587) \\
{[-0.26571]}\end{array}$ & $\begin{array}{r}-32.37573 \\
(25.1089) \\
{[-1.28941]}\end{array}$ & $\begin{array}{r}-9.573194 \\
(9.12930) \\
{[-1.04862]}\end{array}$ & $\begin{array}{r}0.643702 \\
(0.42149) \\
{[1.52720]}\end{array}$ & $\begin{array}{r}30.72831 \\
(28.9441) \\
{[1.06164 \mid}\end{array}$ & $\begin{array}{r}-76.83023 \\
(50.3480) \\
{[-1.52598]}\end{array}$ \\
\hline $\mathrm{D}(\operatorname{IFD}(-4))$ & $\begin{array}{r}0.073320 \\
(0.09319) \\
{[0.78675]}\end{array}$ & $\begin{array}{r}-4.843339 \\
(20.1952) \\
{[-0.23983]}\end{array}$ & $\begin{array}{r}2.205601 \\
(7.34273) \\
{[0.30038]}\end{array}$ & $\begin{array}{r}-0.024087 \\
(0.33901) \\
{[-0.07105]}\end{array}$ & $\begin{array}{r}24.47974 \\
(23.2798) \\
{[11.05154]}\end{array}$ & $\begin{array}{r}-19.95279 \\
(40.4950) \\
{[-0.49272]}\end{array}$ \\
\hline $\mathrm{D}(\mathrm{ITD}(-1))$ & $\begin{array}{r}-0.000337 \\
(0.00228) \\
{[-0.14768]}\end{array}$ & $\begin{array}{r}0.768276 \\
(0.49414) \\
{[1.55478]}\end{array}$ & $\begin{array}{r}0.198400 \\
(0.17966) \\
{[1.10430]}\end{array}$ & $\begin{array}{r}-0.007836 \\
(0.00829) \\
{[-0.94473]}\end{array}$ & $\begin{array}{r}-0.483217 \\
(0.56961) \\
{[-0.84833]}\end{array}$ & $\begin{array}{r}2.694574 \\
(0.99084) \\
{[2.71950]}\end{array}$ \\
\hline $\mathrm{D}(\mathrm{ITD}(-2))$ & $\begin{array}{r}0.001099 \\
(0.00195) \\
{[0.56338}\end{array}$ & $\begin{array}{r}0.283188 \\
(0.42291) \\
{[0.66961]}\end{array}$ & $\begin{array}{r}0.237891 \\
(0.15377) \\
{[1.54709]}\end{array}$ & $\begin{array}{r}-0.011794 \\
(0.00710) \\
{[-1.66134]}\end{array}$ & $\begin{array}{r}-0.777996 \\
(0.48751) \\
{[-1.59586]}\end{array}$ & $\begin{array}{r}1.193873 \\
(0.84802) \\
{[1.40784]}\end{array}$ \\
\hline $\mathrm{D}(\mathrm{ITD}(-3))$ & $\begin{array}{r}0.000831 \\
(0.00152) \\
{[0.54483]}\end{array}$ & $\begin{array}{r}1.136573 \\
(0.33033) \\
{[3.44069]}\end{array}$ & $\begin{array}{r}0.083547 \\
(0.12010 \\
{[0.69562]}\end{array}$ & $\begin{array}{r}-0.009973 \\
(0.00555) \\
{[-1.79848]}\end{array}$ & $\begin{array}{r}-0.618858 \\
(0.38079) \\
{[-1.62520]}\end{array}$ & $\begin{array}{r}0.404995 \\
(0.66238) \\
{[0.61143]}\end{array}$ \\
\hline $\mathrm{D}(\mathrm{ITD}(-4))$ & $\begin{array}{r}-0.004652 \\
(0.00180) \\
{[-2.58574]}\end{array}$ & $\begin{array}{r}0.444676 \\
(0.38989) \\
{[1.14051]}\end{array}$ & $\begin{array}{r}0.144008 \\
(0.14176) \\
{[1.01586]}\end{array}$ & $\begin{array}{r}-0.006487 \\
(0.00654) \\
{[-0.99112]}\end{array}$ & $\begin{array}{r}-0.579920 \\
(0.44944) \\
{[-1.29031]}\end{array}$ & $\begin{array}{r}1.911821 \\
(0.78180) \\
{[2.44540]}\end{array}$ \\
\hline $\mathrm{D}(\operatorname{LR}(-1))$ & $\begin{array}{r}-0.000650 \\
(0.00051) \\
\mid-1.286971\end{array}$ & $\begin{array}{r}0.161576 \\
(0.10945) \\
\mid 1.47626]\end{array}$ & $\begin{array}{r}0.041053 \\
(0.03979) \\
|1.03162|\end{array}$ & $\begin{array}{r}0.002132 \\
(0.00184) \\
\mid 1.16029]\end{array}$ & $\begin{array}{r}-0.010320 \\
(0.12617) \\
{[-0.08179]}\end{array}$ & $\begin{array}{r}0.555676 \\
(0.21947) \\
\text { |2.53196] }\end{array}$ \\
\hline $\mathrm{D}(\mathrm{LR}(-2))$ & $\begin{array}{r}-0.000194 \\
(0.00058) \\
{[-0.33316]}\end{array}$ & $\begin{array}{r}-0.027234 \\
(0.12632) \\
{[-0.21559]}\end{array}$ & $\begin{array}{r}0.032423 \\
(0.04593) \\
|0.70594|\end{array}$ & $\begin{array}{r}-0.000663 \\
(0.00212) \\
{[-0.31271]}\end{array}$ & $\begin{array}{r}-0.055748 \\
(0.14562) \\
{[-0.38285]}\end{array}$ & $\begin{array}{r}-0.013358 \\
(0.25330) \\
\lceil-0.05274]\end{array}$ \\
\hline $\mathrm{D}(\mathrm{LR}(-3))$ & $\begin{array}{r}0.000482 \\
(0.00055) \\
{[0.88183]}\end{array}$ & $\begin{array}{r}0.066066 \\
(0.11836) \\
|0.55817|\end{array}$ & $\begin{array}{r}0.063641 \\
(0.04304) \\
|1.47881|\end{array}$ & $\begin{array}{r}0.000262 \\
(0.00199) \\
{[0.13167 \mid}\end{array}$ & $\begin{array}{r}0.019756 \\
(0.13644) \\
\lceil 0.14480 \mid\end{array}$ & $\begin{array}{r}-0.138442 \\
(0.23734) \\
{[-0.58331]}\end{array}$ \\
\hline $\mathrm{D}(\mathrm{LR}(-4))$ & $\begin{array}{r}-0.001212 \\
(0.00052) \\
{[-2.31350]}\end{array}$ & $\begin{array}{c}0.084151 \\
(0.11352) \\
{[0.74131]}\end{array}$ & $\begin{array}{r}-0.002886 \\
(0.04127) \\
{[-0.06992]}\end{array}$ & $\begin{array}{r}-0.001369 \\
(0.00191) \\
{[-0.71823]}\end{array}$ & $\begin{array}{r}-0.207549 \\
(0.13086) \\
{[-1.58610]}\end{array}$ & $\begin{array}{r}0.419689 \\
(0.22762) \\
\lceil 1.84380\end{array}$ \\
\hline C & $\begin{array}{r}0.008316 \\
(0.00282) \\
{[2.94973]}\end{array}$ & $\begin{array}{r}0.849953 \\
(0.61094) \\
{[1.39121]}\end{array}$ & $\begin{array}{r}-0.390341 \\
(0.22213) \\
{[-1.75725]}\end{array}$ & $\begin{array}{r}-0.009037 \\
(0.01026) \\
{[-0.88122]}\end{array}$ & $\begin{array}{r}-0.006455 \\
(0.70426) \\
{[-0.00917]}\end{array}$ & $\begin{array}{r}2.362337 \\
(1.22505 \\
{[1.92835]}\end{array}$ \\
\hline $\begin{array}{l}\text { R-squared } \\
\text { Adj. R-squared } \\
\text { Sum sq. resids } \\
\text { S.E. equation } \\
\text { F-statistic } \\
\text { Log likelihood } \\
\text { Akaike AIC } \\
\text { Schwarz SC } \\
\text { Mean dependent } \\
\text { S.D. dependent }\end{array}$ & $\begin{array}{l}0.776274 \\
0.428255 \\
0.000543 \\
0.005495 \\
2.230553 \\
200.4512 \\
-7.295795 \\
-6.154215 \\
0.003162 \\
0.007267\end{array}$ & $\begin{array}{l}0.870178 \\
0.668232 \\
25.52043 \\
1.190715 \\
4.308966 \\
-52.33940 \\
3.461251 \\
4.602832 \\
0.041534 \\
2.067238\end{array}$ & $\begin{array}{r}0.917940 \\
0.790291 \\
3.373699 \\
0.432929 \\
7.191131 \\
-4.787875 \\
1.437782 \\
2.579362 \\
0.009574 \\
0.945385\end{array}$ & $\begin{array}{r}0.791313 \\
0.466688 \\
0.007191 \\
0.019988 \\
2.437623 \\
139.7581 \\
-4.713110 \\
-3.571530 \\
-0.000859 \\
0.027370\end{array}$ & $\begin{array}{r}0.709474 \\
0.257544 \\
33.91180 \\
1.372585 \\
1.569876 \\
-59.02008 \\
3.745535 \\
4.887116 \\
0.095745 \\
1.592956\end{array}$ & $\begin{array}{l}0.722104 \\
0.289821 \\
102.6113 \\
2.387599 \\
1.670441 \\
-85.03893 \\
4.852720 \\
5.994301 \\
0.807476 \\
2.833201\end{array}$ \\
\hline \multicolumn{2}{|c|}{$\begin{array}{l}\text { Determinant resid covariance (dof adj.) } \\
\text { Determinant resid covariance } \\
\text { Log likelihood } \\
\text { Akaike information criterion } \\
\text { Schwarz criterion }\end{array}$} & $\begin{array}{r}1.59 \mathrm{E}-09 \\
5.01 \mathrm{E}-12 \\
211.3314 \\
-0.567293 \\
7.226946\end{array}$ & & & & \\
\hline
\end{tabular}


Fig. 3: VEC Estimates of Group 2

\begin{tabular}{|c|c|c|c|c|c|c|}
\hline Cointegrating Eq: & CointEq1 & CointEq2 & CointEq3 & CointEq4 & & \\
\hline $\operatorname{LEX}(-1)$ & 1.000000 & 0.000000 & 0.000000 & 0.000000 & & \\
\hline $\mathrm{BOP}(-1)$ & 0.000000 & 1.000000 & 0.000000 & 0.000000 & & \\
\hline $\operatorname{GDP}(-1)$ & 0.000000 & 0.000000 & 1.000000 & 0.000000 & & \\
\hline $\operatorname{IFN}(-1)$ & 0.000000 & 0.000000 & 0.000000 & 1.000000 & & \\
\hline $\mathrm{IT}(-1)$ & $\begin{array}{r}-0.002457 \\
(0.00404) \\
{[-0.60766]}\end{array}$ & $\begin{array}{r}-0.086383 \\
(0.11866) \\
{[-0.72800]}\end{array}$ & $\begin{array}{r}0.321785 \\
(0.05123) \\
\lceil 6.28090 \mid\end{array}$ & $\begin{array}{r}-0.020162 \\
(0.00402) \\
{[-5.01756]}\end{array}$ & & \\
\hline $\operatorname{LR}(-1)$ & $\begin{array}{r}-0.005386 \\
(0.00084) \\
{[-6.44618]}\end{array}$ & $\begin{array}{r}-0.097163 \\
(0.02452) \\
{[-3.96227]}\end{array}$ & $\begin{array}{r}0.052790 \\
(0.01059) \\
{[4.98594]}\end{array}$ & $\begin{array}{r}0.001787 \\
(0.00083) \\
{[2.15198]}\end{array}$ & & \\
\hline $\mathrm{C}$ & -4.136821 & 2.811186 & -10.16743 & 0.035636 & & \\
\hline Error Correction: & $\mathrm{D}(\mathrm{LEX})$ & $\mathrm{D}(\mathrm{BOP})$ & $\mathrm{D}(\mathrm{GDP})$ & $\mathrm{D}(\mathrm{IFN})$ & $\mathrm{D}(\mathrm{IT})$ & $\mathrm{D}(\mathrm{LR})$ \\
\hline CointEq1 & $\begin{array}{r}0.267366 \\
(0.10117) \\
{[2.64286]}\end{array}$ & $\begin{array}{r}69.52084 \\
(24.8837) \\
{[2.79383]}\end{array}$ & $\begin{array}{c}-22.93808 \\
(8.55418) \\
{[-2.68151]}\end{array}$ & $\begin{array}{c}-0.182014 \\
(0.34383) \\
{[-0.52938]}\end{array}$ & $\begin{array}{r}31.10990 \\
(23.9646) \\
{[1.29816]}\end{array}$ & $\begin{array}{r}46.23794 \\
(54.3397) \\
{[0.85091]}\end{array}$ \\
\hline CointEq2 & $\begin{array}{r}-0.007725 \\
(0.00214) \\
{[-3.61294]}\end{array}$ & $\begin{array}{r}-1.555633 \\
(0.52591) \\
{[-2.95798]}\end{array}$ & $\begin{array}{r}0.355015 \\
(0.18079) \\
{[1.96368]}\end{array}$ & $\begin{array}{r}0.007609 \\
(0.00727) \\
{[1.04716]}\end{array}$ & $\begin{array}{r}-0.257175 \\
(0.50649) \\
{[-0.50776]}\end{array}$ & $\begin{array}{r}0.048229 \\
(1.14846) \\
{[0.04199}\end{array}$ \\
\hline CointEq3 & $\begin{array}{r}-5.81 \mathrm{E}-05 \\
(0.00252) \\
{[-0.02308]}\end{array}$ & $\begin{array}{r}-1.630577 \\
(0.61940) \\
{[-2.63251]}\end{array}$ & $\begin{array}{r}-0.575564 \\
(0.21293) \\
{[-2.70308]}\end{array}$ & $\begin{array}{c}0.029274 \\
(0.00856) \\
{[3.42042]}\end{array}$ & $\begin{array}{r}0.956453 \\
(0.59652) \\
{[1.60338]}\end{array}$ & $\begin{array}{r}-0.053064 \\
(1.35261) \\
{[-0.03923]}\end{array}$ \\
\hline CointEq4 & $\begin{array}{r}0.203064 \\
(0.08964) \\
{[2.26536]}\end{array}$ & $\begin{array}{r}25.98865 \\
(22.0485) \\
{[1.17870]}\end{array}$ & $\begin{array}{r}-16.99199 \\
(7.57953) \\
{[-2.24183]}\end{array}$ & $\begin{array}{r}-0.010388 \\
(0.30465) \\
{[-0.03410]}\end{array}$ & $\begin{array}{r}42.81175 \\
(21.2341) \\
{[2.01618]}\end{array}$ & $\begin{array}{r}26.54014 \\
(48.1483) \\
{[0.55122]}\end{array}$ \\
\hline $\mathrm{D}(\operatorname{LEX}(-1))$ & $\begin{array}{r}-0.887306 \\
(0.22369) \\
{[-3.96672]}\end{array}$ & $\begin{array}{r}-92.81760 \\
(55.0205) \\
{[-1.68696]}\end{array}$ & $\begin{array}{r}22.70279 \\
(18.9142) \\
{[1.20030 \mid}\end{array}$ & $\begin{array}{r}1.934084 \\
(0.76024) \\
{[2.54404]}\end{array}$ & $\begin{array}{c}-20.91654 \\
(52.9882) \\
{[-0.39474]}\end{array}$ & $\begin{array}{r}-11.23318 \\
(120.151) \\
{[-0.09349]}\end{array}$ \\
\hline $\mathrm{D}(\operatorname{LEX}(-2))$ & $\begin{array}{r}-0.273356 \\
(0.22681) \\
{[-1.20522]}\end{array}$ & $\begin{array}{r}-197.6945 \\
(55.7885) \\
{[-3.54364]}\end{array}$ & $\begin{array}{r}37.16047 \\
(19.1782) \\
{[1.93764]}\end{array}$ & $\begin{array}{r}0.805851 \\
(0.77085) \\
{[1.04540]}\end{array}$ & $\begin{array}{r}-8.104306 \\
(53.7278) \\
{[-0.15084]}\end{array}$ & $\begin{array}{r}-139.6130 \\
(121.828) \\
{[-1.14599]}\end{array}$ \\
\hline $\mathrm{D}(\operatorname{LEX}(-3))$ & $\begin{array}{r}-0.434875 \\
(0.25833) \\
{[-1.68339]}\end{array}$ & $\begin{array}{r}-180.2857 \\
(63.5423) \\
{[-2.83725]}\end{array}$ & $\begin{array}{r}47.49833 \\
(21.8437) \\
{[2.17446]}\end{array}$ & $\begin{array}{c}0.772913 \\
(0.87799) \\
{[0.88032]}\end{array}$ & $\begin{array}{r}25.37166 \\
(61.1952) \\
{[0.41460]}\end{array}$ & $\begin{array}{r}-194.5345 \\
(138.760) \\
{[-1.40195]}\end{array}$ \\
\hline $\mathrm{D}(\operatorname{LEX}(-4))$ & $\begin{array}{r}-0.388672 \\
(0.23760) \\
{[-1.63580]}\end{array}$ & $\begin{array}{r}-49.99670 \\
(58.4433) \\
{[-0.85547]}\end{array}$ & $\begin{array}{r}31.89493 \\
(200.0908) \\
\lceil 1.58754]\end{array}$ & $\begin{array}{r}0.584425 \\
(0.80753) \\
{[0.72372]}\end{array}$ & $\begin{array}{c}10.22713 \\
(56.2846) \\
{[0.18170]}\end{array}$ & $\begin{array}{r}-113.8768 \\
(127.625) \\
{[-0.89227]}\end{array}$ \\
\hline $\mathrm{D}(\mathrm{BOP}(-1))$ & $\begin{array}{r}0.006183 \\
(0.00172) \\
{[3.58796]}\end{array}$ & $\begin{array}{r}0.583779 \\
(0.42388) \\
{[1.37722]}\end{array}$ & $\begin{array}{r}-0.247914 \\
(0.14572) \\
{[-1.70134]}\end{array}$ & $\begin{array}{r}-0.008762 \\
(0.00586) \\
{[-1.49594]}\end{array}$ & $\begin{array}{r}-0.092784 \\
(0.40823) \\
{[-0.22729]}\end{array}$ & $\begin{array}{r}0.077752 \\
(0.92565) \\
{[0.08400]}\end{array}$ \\
\hline $\mathrm{D}(\mathrm{BOP}(-2))$ & $\begin{array}{r}0.004528 \\
(0.00161) \\
\mid 2.81825]\end{array}$ & $\begin{array}{r}0.532203 \\
(0.39518) \\
{[1.34673]}\end{array}$ & $\begin{array}{r}-0.361067 \\
(0.13585) \\
{[-2.65783]}\end{array}$ & $\begin{array}{r}-0.006585 \\
(0.00546) \\
{[-1.20591]}\end{array}$ & $\begin{array}{c}-0.084234 \\
(0.38059) \\
{[-0.22133]}\end{array}$ & $\begin{array}{r}0.750926 \\
(0.86298) \\
{[0.87016]}\end{array}$ \\
\hline $\mathrm{D}(\mathrm{BOP}(-3))$ & $\begin{array}{r}0.005543 \\
(0.00142) \\
{[3.89712]}\end{array}$ & $\begin{array}{r}-0.165781 \\
(0.34984) \\
{[-0.47388]}\end{array}$ & $\begin{array}{c}-0.263406 \\
(0.12026) \\
{[-2.19026]}\end{array}$ & $\begin{array}{r}-0.002165 \\
(0.00483) \\
{[-0.44797]}\end{array}$ & $\begin{array}{c}0.082849 \\
(0.33692) \\
{[0.24591]}\end{array}$ & $\begin{array}{r}-0.057624 \\
(0.76396) \\
{[-0.07543]}\end{array}$ \\
\hline $\mathrm{D}(\mathrm{BOP}(-4))$ & $\begin{array}{r}0.004073 \\
(0.00092) \\
{[4.41034]}\end{array}$ & $\begin{array}{r}-0.440787 \\
(0.22714) \\
{[-1.94060]}\end{array}$ & $\begin{array}{r}-0.044301 \\
(0.07808) \\
{[-0.56736]}\end{array}$ & $\begin{array}{r}-0.000673 \\
(0.00314) \\
{[-0.21451]}\end{array}$ & $\begin{array}{r}0.053662 \\
(0.21875) \\
{[0.24531]}\end{array}$ & $\begin{array}{r}-0.772056 \\
(0.49602) \\
{[-1.55651]}\end{array}$ \\
\hline $\mathrm{D}(\mathrm{GDP}(-1))$ & $\begin{array}{r}0.002567 \\
(0.00222) \\
{[1.15378]}\end{array}$ & $\begin{array}{c}1.008222 \\
(0.54720) \\
{[1.84252]}\end{array}$ & $\begin{array}{r}0.122286 \\
(0.18811) \\
{[0.65008]}\end{array}$ & $\begin{array}{r}-0.011684 \\
(0.00756) \\
{[-1.54535]}\end{array}$ & $\begin{array}{r}-0.270775 \\
(0.52698) \\
{[-0.51382]}\end{array}$ & $\begin{array}{r}1.205396 \\
(1.19494) \\
{[1.00875]}\end{array}$ \\
\hline $\mathrm{D}(\mathrm{GDP}(-2))$ & $\begin{array}{r}0.004369 \\
(0.00181) \\
{[2.41461]}\end{array}$ & $\begin{array}{c}-0.533107 \\
(0.44506) \\
{[-1.19782]}\end{array}$ & $\begin{array}{r}-0.077941 \\
(0.15300) \\
{[-0.50943]}\end{array}$ & $\begin{array}{r}-0.007566 \\
(0.00615) \\
{[-1.23027]}\end{array}$ & $\begin{array}{c}0.210044 \\
(0.42862) \\
{[0.49004]}\end{array}$ & $\begin{array}{r}0.192249 \\
(0.97191) \\
{[0.19781]}\end{array}$ \\
\hline
\end{tabular}




\begin{tabular}{|c|c|c|c|c|c|c|}
\hline $\mathrm{D}(\mathrm{GDP}(-3))$ & $\begin{array}{r}0.003544 \\
(0.00144) \\
{[2.46498]}\end{array}$ & $\begin{array}{r}-0.171149 \\
(0.35365) \\
{[-0.48395]}\end{array}$ & $\begin{array}{r}-0.083884 \\
(0.12157) \\
{[-0.68998]}\end{array}$ & $\begin{array}{r}-0.000893 \\
(0.00489) \\
{[-0.18275]}\end{array}$ & $\begin{array}{c}0.224604 \\
(0.34059) \\
{[0.65945]}\end{array}$ & $\begin{array}{c}-0.207202 \\
(0.77229) \\
{[-0.26830]}\end{array}$ \\
\hline $\mathrm{D}(\mathrm{GDP}(-4))$ & $\begin{array}{r}0.001104 \\
(0.00143) \\
{[0.77238]}\end{array}$ & $\begin{array}{r}-0.219367 \\
(0.35171) \\
{[-0.62371\}}\end{array}$ & $\begin{array}{r}0.444557 \\
(0.12091) \\
{[3.67684]}\end{array}$ & $\begin{array}{c}0.003996 \\
(0.00486) \\
{[0.82231]}\end{array}$ & $\begin{array}{r}0.426180 \\
(0.33872) \\
{[1.25820]}\end{array}$ & $\begin{array}{r}-0.437859 \\
(0.76805) \\
{[-0.57009]}\end{array}$ \\
\hline $\mathrm{D}(\mathrm{IFN}(-1))$ & $\begin{array}{r}-0.213093 \\
(0.09801) \\
{[-2.17420]}\end{array}$ & $\begin{array}{r}3.475126 \\
(24.1076) \\
\lceil 0.14415]\end{array}$ & $\begin{array}{r}-0.283080 \\
(8.28737) \\
{[-0.03416]}\end{array}$ & $\begin{array}{r}0.737691 \\
(0.33310) \\
\lceil 2.21460]\end{array}$ & $\begin{array}{r}4.586264 \\
(23.2171) \\
{[0.19754 \mid}\end{array}$ & $\begin{array}{r}-21.71477 \\
(52.6448) \\
{[-0.41248]}\end{array}$ \\
\hline $\mathrm{D}(\mathrm{IFN}(-2))$ & $\begin{array}{r}-0.051334 \\
(0.08817) \\
{[-0.58224]}\end{array}$ & $\begin{array}{r}-27.46975 \\
(21.6862) \\
{[-1.26669]}\end{array}$ & $\begin{array}{r}7.716619 \\
(7.45499) \\
{[1.03509]}\end{array}$ & $\begin{array}{r}-0.187252 \\
(0.29965) \\
{[-0.62491]}\end{array}$ & $\begin{array}{r}-13.50730 \\
(20.8852) \\
{[-0.64674]}\end{array}$ & $\begin{array}{r}-13.88046 \\
(47.3572) \\
{[-0.29310]}\end{array}$ \\
\hline $\mathrm{D}(\mathrm{IFN}(-3))$ & $\begin{array}{r}-0.111335 \\
(0.08736) \\
{[-1.27437]}\end{array}$ & $\begin{array}{r}-12.71309 \\
(21.4891) \\
{[-0.59161]}\end{array}$ & $\begin{array}{r}-0.337799 \\
(7.38724) \\
{[-0.04573]}\end{array}$ & $\begin{array}{r}0.333758 \\
(0.29692) \\
{[1.12405]}\end{array}$ & $\begin{array}{r}-14.81514 \\
(20.6954) \\
{[-0.71587]}\end{array}$ & $\begin{array}{r}-9.129443 \\
(46.9268) \\
{[-0.19455]}\end{array}$ \\
\hline $\mathrm{D}(\mathrm{IFN}(-4))$ & $\begin{array}{r}-0.028764 \\
(0.07075) \\
{[-0.40655]}\end{array}$ & $\begin{array}{r}-15.00029 \\
(17.4027) \\
{[-0.86195]}\end{array}$ & $\begin{array}{r}5.899108 \\
(5.98247) \\
{[0.98607]}\end{array}$ & $\begin{array}{r}-0.059613 \\
(0.24046) \\
{[-0.24791]}\end{array}$ & $\begin{array}{r}8.718822 \\
(16.7599) \\
{[0.52022]}\end{array}$ & $\begin{array}{r}-12.51881 \\
(38.0031) \\
{[-0.32942]}\end{array}$ \\
\hline $\mathrm{D}(\mathrm{IT}(-1))$ & $\begin{array}{r}0.003065 \\
(0.00186) \\
{[1.64371]}\end{array}$ & $\begin{array}{r}1.019265 \\
(0.45873) \\
{[2.22194]}\end{array}$ & $\begin{array}{c}0.018562 \\
(0.15769) \\
{[0.11771]}\end{array}$ & $\begin{array}{r}-0.008294 \\
(0.00634) \\
{[-1.30848]}\end{array}$ & $\begin{array}{r}0.151502 \\
(0.44178) \\
{[0.34293]}\end{array}$ & $\begin{array}{r}1.715326 \\
(1.00174) \\
{[1.71234]}\end{array}$ \\
\hline $\mathrm{D}(\mathrm{IT}(-2))$ & $\begin{array}{r}0.003760 \\
(0.00155) \\
{[2.43188]}\end{array}$ & $\begin{array}{r}0.075365 \\
(0.38027) \\
{[0.19819]}\end{array}$ & $\begin{array}{r}-0.007487 \\
(0.13072) \\
{[-0.05728]}\end{array}$ & $\begin{array}{r}-0.013942 \\
(0.00525) \\
{[-2.65346]}\end{array}$ & $\begin{array}{r}-0.356272 \\
(0.36622) \\
{[-0.97283]}\end{array}$ & $\begin{array}{r}-0.204337 \\
(0.83041) \\
{[-0.24607]}\end{array}$ \\
\hline $\mathrm{D}(\mathrm{IT}(-3))$ & $\begin{array}{r}0.001188 \\
(0.00135) \\
{[0.87720]}\end{array}$ & $\begin{array}{r}1.299817 \\
(0.33300) \\
\lceil 3.90340 \mid\end{array}$ & $\begin{array}{r}0.027522 \\
(0.11447) \\
|0.24043|\end{array}$ & $\begin{array}{r}-0.011454 \\
(0.00460) \\
{[-2.48945]}\end{array}$ & $\begin{array}{r}-0.251733 \\
(0.32070) \\
{[-0.78496]}\end{array}$ & $\begin{array}{r}0.163985 \\
(0.72718) \\
{[0.22551]}\end{array}$ \\
\hline $\mathrm{D}(\mathrm{IT}(-4))$ & $\begin{array}{r}-0.002635 \\
(0.00169) \\
{[-1.55507]}\end{array}$ & $\begin{array}{r}0.621658 \\
(0.41676) \\
{[1.49166]}\end{array}$ & $\begin{array}{r}0.042099 \\
(0.14327) \\
{[0.29385]}\end{array}$ & $\begin{array}{r}-0.010580 \\
(0.00576) \\
{[-1.83728]}\end{array}$ & $\begin{array}{r}-0.232097 \\
(0.40136) \\
{[-0.57827]}\end{array}$ & $\begin{array}{r}1.216745 \\
(0.91009) \\
{[1.33695]}\end{array}$ \\
\hline $\mathrm{D}(\mathrm{LR}(-1))$ & $\begin{array}{r}-0.000267 \\
(0.00047 \\
{[-0.56824]}\end{array}$ & $\begin{array}{r}0.294551 \\
(0.11536) \\
{[2.55328}\end{array}$ & $\begin{array}{c}0.028567 \\
(0.03966) \\
{[0.72034]}\end{array}$ & $\begin{array}{c}0.000626 \\
(0.00159) \\
{[0.39264]}\end{array}$ & $\begin{array}{r}0.004603 \\
(0.11110) \\
{[0.04143]}\end{array}$ & $\begin{array}{r}0.544844 \\
(0.25192) \\
{[2.16276]}\end{array}$ \\
\hline $\mathrm{D}(\mathrm{LR}(-2))$ & $\begin{array}{c}0.000277 \\
(0.00050) \\
{[0.55230]}\end{array}$ & $\begin{array}{r}-0.060255 \\
(0.12323) \\
{[-0.48896]}\end{array}$ & $\begin{array}{r}-0.000949 \\
(0.04236) \\
{[-0.02241]}\end{array}$ & $\begin{array}{r}-0.002029 \\
(0.00170) \\
{[-1.19135]}\end{array}$ & $\begin{array}{r}-0.022665 \\
(0.11868) \\
{[-0.19098]}\end{array}$ & $\begin{array}{r}-0.173473 \\
(0.26911) \\
{[-0.64462]}\end{array}$ \\
\hline $\mathrm{D}(\mathrm{LR}(-3))$ & $\begin{array}{r}0.000717 \\
(0.00050) \\
\lceil 1.44353\rceil\end{array}$ & $\begin{array}{r}0.031417 \\
(0.12223) \\
|0.25702|\end{array}$ & $\begin{array}{r}0.048363 \\
(0.04202) \\
|1.15095|\end{array}$ & $\begin{array}{r}-0.001002 \\
(0.00169) \\
{[-0.59344]}\end{array}$ & $\begin{array}{r}-0.028824 \\
(0.11772) \\
{[-0.24486]}\end{array}$ & $\begin{array}{r}-0.267732 \\
(0.26693) \\
{[-1.00301]}\end{array}$ \\
\hline $\mathrm{D}(\mathrm{LR}(-4))$ & $\begin{array}{r}-0.001044 \\
(0.00049) \\
{[-2.15253]}\end{array}$ & $\begin{array}{r}0.117783 \\
(0.11935) \\
\lceil 0.98684 \mid\end{array}$ & $\begin{array}{r}-0.037181 \\
(0.04103) \\
{[-0.90618]}\end{array}$ & $\begin{array}{r}-0.003262 \\
(0.00165) \\
\mid-1.97775]\end{array}$ & $\begin{array}{r}-0.153544 \\
(0.11495) \\
\Gamma-1.33579]\end{array}$ & $\begin{array}{r}0.302963 \\
(0.26064) \\
{[1.16238 \mid}\end{array}$ \\
\hline C & $\begin{array}{r}0.009103 \\
(0.00222 \\
{[4.09844]}\end{array}$ & $\begin{array}{r}1.254924 \\
(0.54631) \\
{[2.29707]}\end{array}$ & $\begin{array}{r}-0.425685 \\
(0.18780) \\
{[-2.26664]}\end{array}$ & $\begin{array}{r}-0.008639 \\
(0.00755) \\
{[-1.14448]}\end{array}$ & $\begin{array}{r}0.169597 \\
(0.52614) \\
{[0.32235]}\end{array}$ & $\begin{array}{r}1.887839 \\
(1.19301) \\
{[1.58241]}\end{array}$ \\
\hline $\begin{array}{l}\text { R-squared } \\
\text { Adj. R-squared } \\
\text { Sum sq. resids } \\
\text { S.E. equation } \\
\text { F-statistic } \\
\text { Log likelihood } \\
\text { Akaike AIC } \\
\text { Schwarz SC } \\
\text { Mean dependent } \\
\text { S.D. dependent }\end{array}$ & $\begin{array}{l}0.822454 \\
0.546270 \\
0.000431 \\
0.004895 \\
2.977926 \\
205.8842 \\
-7.526986 \\
-6.385406 \\
0.003162 \\
0.007267\end{array}$ & $\begin{array}{l}0.867265 \\
0.660789 \\
26.09299 \\
1.203998 \\
4.200308 \\
-52.86081 \\
3.483439 \\
4.625019 \\
0.041534 \\
2.067238\end{array}$ & $\begin{array}{r}0.924998 \\
0.808327 \\
3.083544 \\
0.413894 \\
7.928293 \\
-2.674516 \\
1.347852 \\
2.489432 \\
0.009574 \\
0.945385\end{array}$ & $\begin{array}{l}0.895378 \\
0.732632 \\
0.004982 \\
0.016636 \\
5.501688 \\
148.3851 \\
-5.080216 \\
-3.938636 \\
-0.001184 \\
0.032173\end{array}$ & $\begin{array}{r}0.795607 \\
0.477663 \\
24.20096 \\
1.159525 \\
2.502350 \\
-51.09186 \\
3.408164 \\
4.549745 \\
0.026596 \\
1.604371\end{array}$ & $\begin{array}{l}0.663011 \\
0.138806 \\
124.4308 \\
2.629225 \\
1.264794 \\
-89.56977 \\
5.045522 \\
6.187103 \\
0.807476 \\
2.833201\end{array}$ \\
\hline \multicolumn{2}{|c|}{$\begin{array}{l}\text { Determinant resid covariance (dof adj.) } \\
\text { Determinant resid covariance } \\
\text { Log likelihood } \\
\text { Akaike information criterion } \\
\text { Schwarz criterion }\end{array}$} & $\begin{array}{r}2.79 \mathrm{E}-09 \\
8.79 \mathrm{E}-12 \\
198.1011 \\
-0.004300 \\
7.789938\end{array}$ & & & & \\
\hline
\end{tabular}


Fig. 4: Equation Estimates of Group 2

\begin{tabular}{|c|c|c|c|c|}
\hline 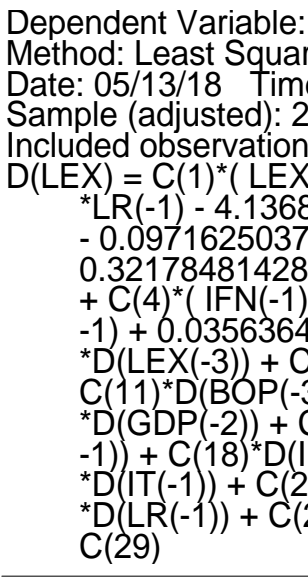 & 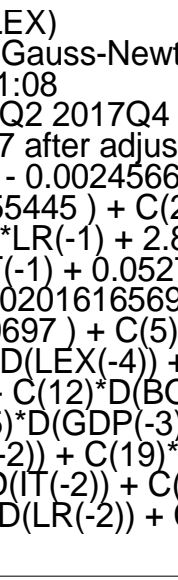 & 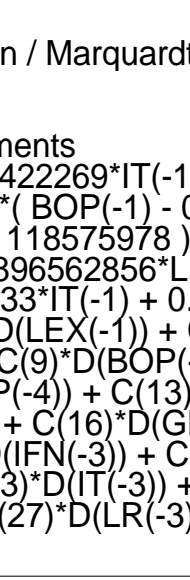 & $\begin{array}{l}\text { steps) } \\
\\
-0.0053857 \\
0863828406 \\
+C(3)^{*}(\text { GDF } \\
(-1)-10.167 \\
0178701997 \\
(6)^{*} \mathrm{D}(\mathrm{LEX}(- \\
)^{\prime}+\mathrm{C}(10)^{*} \mathrm{D} \\
\mathrm{D}(\mathrm{GDP}(-1)) \\
\mathrm{P}(-4))+\mathrm{C}(1 \\
20)^{*} \mathrm{D}(\mathrm{IFN}(-4 \\
\mathrm{C}(24)^{*} \mathrm{D}(\mathrm{II}(- \\
+\mathrm{C}(28)^{*} \mathrm{D}(\mathrm{L}\end{array}$ & $\begin{array}{l} \\
\\
0865499 \\
642^{*} I T(-1 \\
(-1)+ \\
4285822) \\
717^{*} \mathrm{LR}( \\
\text { (BOP }(-2) \\
+\mathrm{C}(14) \\
7)^{*} \mathrm{D}(\mathrm{IIN}( \\
))+\mathrm{C}(21) \\
4))+\mathrm{C}(2 \\
\mathrm{R}(-4))+ \\
\end{array}$ \\
\hline & Coefficient & Std. Error & t-Statistic & Prob. \\
\hline 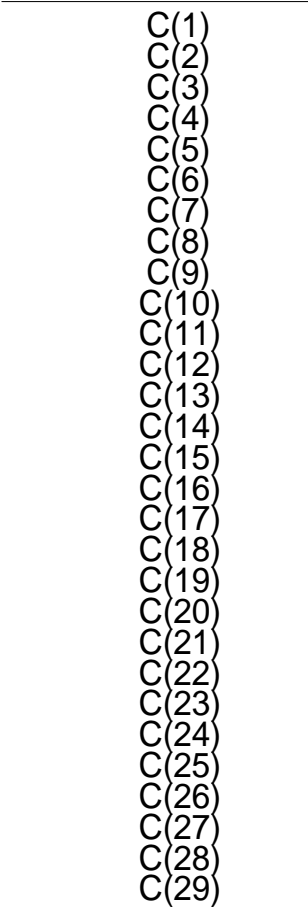 & $\begin{array}{r}0.267366 \\
-0.007725 \\
-5.81 \mathrm{E}-05 \\
0.203064 \\
-0.887306 \\
-0.273356 \\
-0.434875 \\
-0.388672 \\
0.006183 \\
0.004528 \\
0.005543 \\
0.004073 \\
0.002567 \\
0.004369 \\
0.003544 \\
0.001104 \\
-0.213093 \\
-0.051334 \\
-0.111335 \\
-0.028764 \\
0.003065 \\
0.003760 \\
0.001188 \\
-0.002635 \\
-0.000267 \\
0.000277 \\
0.000717 \\
-0.001044 \\
0.009103\end{array}$ & $\begin{array}{l}0.101165 \\
0.002138 \\
0.002518 \\
0.089639 \\
0.223687 \\
0.226809 \\
0.258333 \\
0.237603 \\
0.001723 \\
0.001607 \\
0.001422 \\
0.000923 \\
0.002225 \\
0.001809 \\
0.001438 \\
0.001430 \\
0.098010 \\
0.088166 \\
0.087365 \\
0.070751 \\
0.001865 \\
0.001546 \\
0.001354 \\
0.001694 \\
0.000469 \\
0.000501 \\
0.000497 \\
0.000485 \\
0.002221\end{array}$ & $\begin{array}{r}2.642865 \\
-3.612942 \\
-0.023079 \\
2.265358 \\
-3.966724 \\
-1.205222 \\
-1.683388 \\
-1.635804 \\
3.587963 \\
2.818248 \\
3.897120 \\
4.410344 \\
1.153780 \\
2.414609 \\
2.464976 \\
0.772380 \\
-2.174201 \\
-0.582245 \\
-1.274372 \\
-0.406550 \\
1.643708 \\
2.431876 \\
0.877202 \\
-1.555068 \\
-0.568241 \\
0.552299 \\
1.443528 \\
-2.152534 \\
4.098442\end{array}$ & $\begin{array}{l}0.0165 \\
0.0020 \\
0.9818 \\
0.0361 \\
0.0009 \\
0.2437 \\
0.1096 \\
0.1192 \\
0.0021 \\
0.0114 \\
0.0011 \\
0.0003 \\
0.2637 \\
0.0266 \\
0.0240 \\
0.4499 \\
0.0433 \\
0.5676 \\
0.2187 \\
0.6891 \\
0.1176 \\
0.0257 \\
0.3919 \\
0.1373 \\
0.5769 \\
0.5875 \\
0.1661 \\
0.0452 \\
0.0007\end{array}$ \\
\hline $\begin{array}{l}\text { R-squared } \\
\text { Adjusted R-squared } \\
\text { S.E. of regression } \\
\text { Sum squared resid } \\
\text { Log likelihood } \\
\text { F-statistic } \\
\text { Prob(F-statistic) }\end{array}$ & $\begin{array}{l}0.822454 \\
0.546270 \\
0.004895 \\
0.000431 \\
205.8842 \\
2.977926 \\
0.009360\end{array}$ & $\begin{array}{l}\text { Mean depen } \\
\text { S.D. depeno } \\
\text { Akaike info } \\
\text { Schwarz crit } \\
\text { Hannan-Qui } \\
\text { Durbin-Wats }\end{array}$ & $\begin{array}{l}\text { lent var } \\
\text { nt var } \\
\text { iterion } \\
\text { rion } \\
\text { n criter. } \\
\text { n stat }\end{array}$ & $\begin{array}{r}0.003162 \\
0.007267 \\
-7.526986 \\
-6.385406 \\
-7.097402 \\
1.990345\end{array}$ \\
\hline
\end{tabular}


6. Residual unit root test of Group 2

Fig. 5: Residual Unit Root Test of Group 2

Group unit root test: summary

Series: RESID01, RESID02, RESID03, RESID04, RESID05, RESID06

Date: 05/13/18 Time: 04:13

Sample: 2005Q1 2017Q4

Exogenous variables: Individual effects

Automatic selection of maximum lags

Automatic lag length selection based on SIC: 0

Newey-West automatic bandwidth selection and Bartlett kernel

Balanced observations for each test

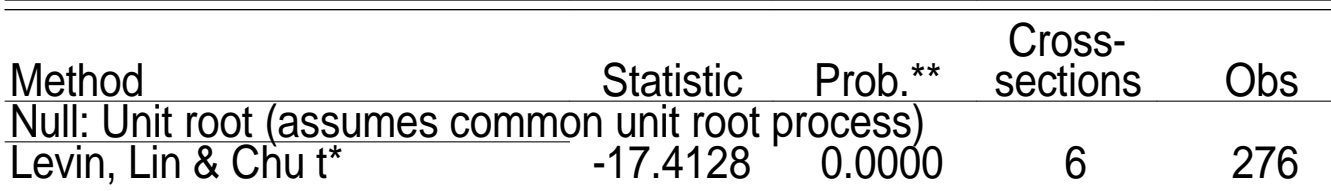

Null: Unit root (assumes individual unit root process)

$\begin{array}{lrrrr}\text { Im, Pesaran and Shin W-stat } & -15.9963 & 0.0000 & 6 & 276 \\ \text { ADF - Fisher Chi-square } & 186.871 & 0.0000 & 6 & 276 \\ \text { PP - Fisher Chi-square } & 198.788 & 0.0000 & 6 & 276\end{array}$

${ }^{\star *}$ Probabilities for Fisher tests are computed using an asymptotic Chi -square distribution. All other tests assume asymptotic normality. 


\section{Impulse Response}

Fig. 18: Impulse Response of Group 2

Response to Cholesky One S.D. Innovations

Response of LEX to LEX

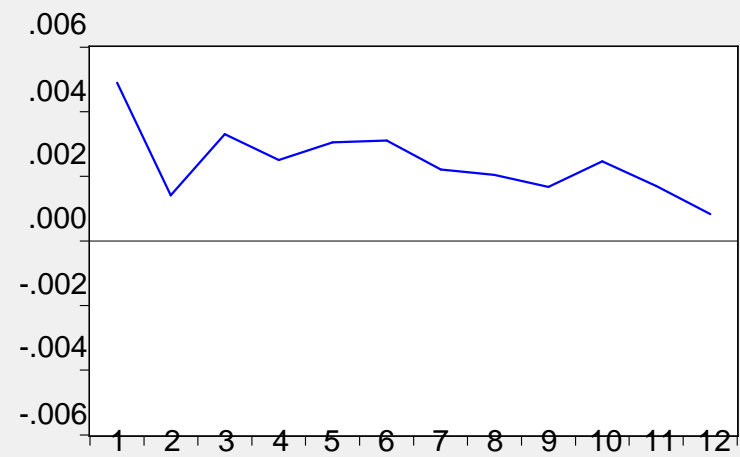

Response of LEX to GDP

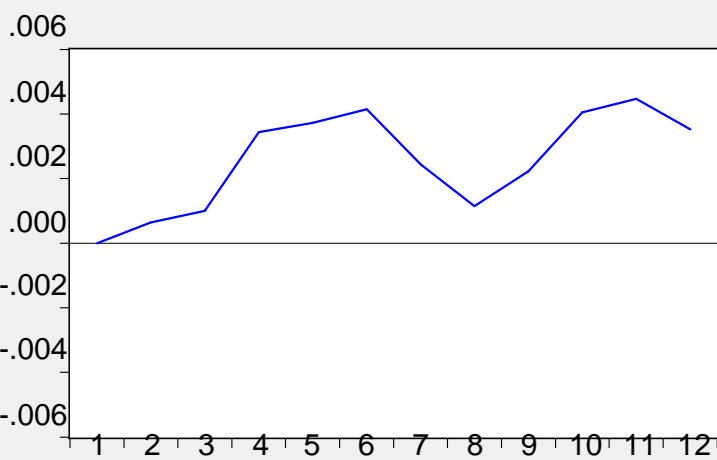

Response of LEX to IT

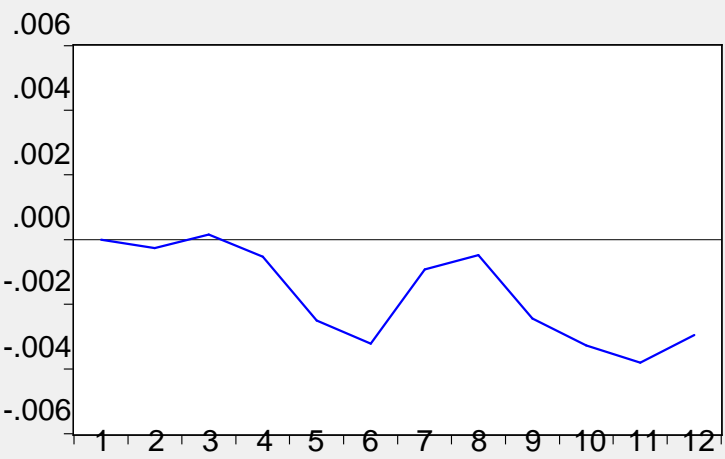

Response of LEX to BOP

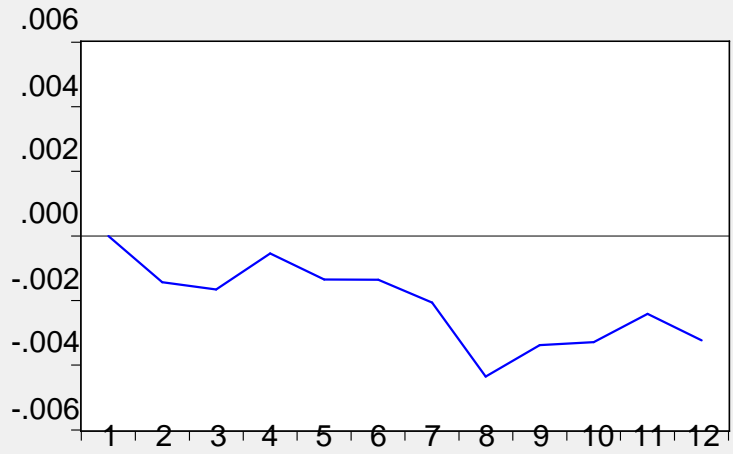

Response of LEX to IFN

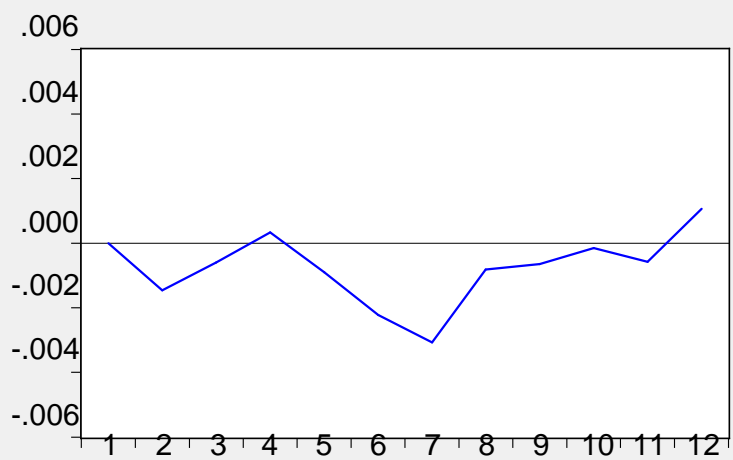

Response of LEX to LR

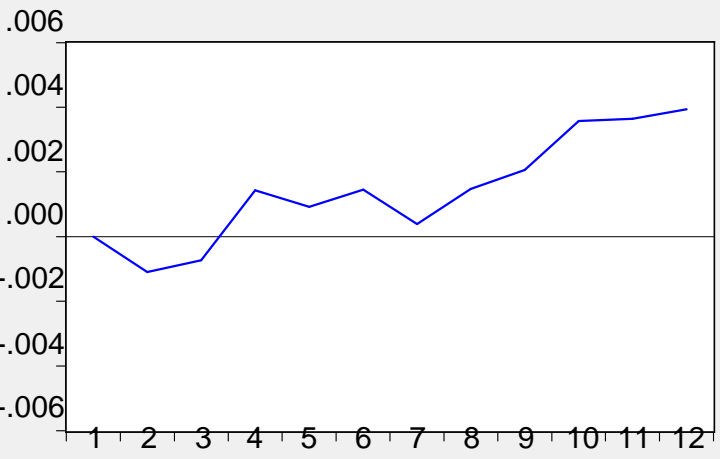


8. Variance Decomposition:

Table 8: Variance Decomposition Table of Group 2

\begin{tabular}{|c|c|c|c|c|c|c|c|}
\hline Period & S.E. & LEX & BOP & GDP & IFN & IT & LR \\
\hline $\begin{array}{c}1 \\
2 \\
3 \\
4 \\
5 \\
6 \\
7 \\
8 \\
9 \\
10\end{array}$ & $\begin{array}{l}0.004895 \\
0.005640 \\
0.006883 \\
0.008256 \\
0.010054 \\
0.012130 \\
0.013138 \\
0.014145 \\
0.015160 \\
0.016930\end{array}$ & $\begin{array}{l}100.0000 \\
81.55059 \\
77.83300 \\
63.29504 \\
51.88364 \\
42.21581 \\
38.82426 \\
35.59320 \\
32.20120 \\
27.94677\end{array}$ & $\begin{array}{l}0.000000 \\
6.441034 \\
10.06324 \\
7.430047 \\
6.810376 \\
5.926870 \\
7.508314 \\
15.92240 \\
18.82702 \\
18.87246\end{array}$ & $\begin{array}{l}0.000000 \\
1.314589 \\
2.974128 \\
19.35409 \\
26.77369 \\
30.05419 \\
29.04531 \\
25.71606 \\
24.52896 \\
25.38108\end{array}$ & $\begin{array}{l}0.000000 \\
6.661532 \\
5.230976 \\
3.803588 \\
3.364725 \\
5.657334 \\
10.28240 \\
9.201335 \\
8.189146 \\
6.575036\end{array}$ & $\begin{array}{l}0.000000 \\
0.221865 \\
0.197825 \\
0.538060 \\
6.567576 \\
11.55532 \\
10.34214 \\
9.038508 \\
10.46814 \\
12.13245\end{array}$ & $\begin{array}{l}0.000000 \\
3.810392 \\
3.700827 \\
5.579172 \\
4.599995 \\
4.590468 \\
3.997585 \\
4.528506 \\
5.785532 \\
9.092203\end{array}$ \\
\hline
\end{tabular}

Cholesky Ordering: LEX BOP GDP IFN IT LR 


\section{Granger causality}

Fig. 19: Granger Causality of Group 2

Pairwise Granger Causality I ests

Date: $05 / 11 / 18$ Time: $14: 12$

Sample: 2005Q1 2017Q4

Lags: 4

\begin{tabular}{|c|c|c|c|}
\hline Null Hypothesis: & Obs & F-Statistic & Prob. \\
\hline $\begin{array}{l}\text { DGDP does not Granger Cause DBOP } \\
\text { DBOP does not Granger Cause DGDP }\end{array}$ & 47 & $\begin{array}{l}1.66258 \\
4.46159\end{array}$ & $\begin{array}{l}0.1788 \\
0.0047\end{array}$ \\
\hline $\begin{array}{l}\text { DIFN does not Granger Cause DBOP } \\
\text { DBOP does not Granger Cause DIFN }\end{array}$ & 47 & $\begin{array}{l}0.96907 \\
2.10108\end{array}$ & $\begin{array}{l}0.4357 \\
0.0997\end{array}$ \\
\hline $\begin{array}{l}\text { DIT does not Granger Cause DBOP } \\
\text { DBOP does not Granger Cause DIT }\end{array}$ & 47 & $\begin{array}{l}4.18733 \\
2.49362\end{array}$ & $\begin{array}{l}0.0066 \\
0.0591\end{array}$ \\
\hline $\begin{array}{l}\text { DLEX does not Granger Cause DBOP } \\
\text { DBOP does not Granger Cause DLEX }\end{array}$ & 47 & $\begin{array}{l}1.54421 \\
1.01970\end{array}$ & $\begin{array}{l}0.2091 \\
0.4095\end{array}$ \\
\hline $\begin{array}{l}\text { DLR does not Granger Cause DBOP } \\
\text { DBOP does not Granger Cause DLR }\end{array}$ & 47 & $\begin{array}{l}1.63804 \\
1.04165\end{array}$ & $\begin{array}{l}0.1847 \\
0.3986\end{array}$ \\
\hline $\begin{array}{l}\text { DIFN does not Granger Cause DGDP } \\
\text { DGDP does not Granger Cause DIFN }\end{array}$ & 47 & $\begin{array}{l}5.65852 \\
1.20969\end{array}$ & $\begin{array}{l}0.0011 \\
0.3227\end{array}$ \\
\hline $\begin{array}{l}\text { DIT does not Granger Cause DGDP } \\
\text { DGDP does not Granger Cause DIT }\end{array}$ & 47 & $\begin{array}{l}5.57816 \\
1.33272\end{array}$ & $\begin{array}{l}0.0012 \\
0.2755 \\
\end{array}$ \\
\hline $\begin{array}{l}\text { DLEX does not Granger Cause DGDP } \\
\text { DGDP does not Granger Cause DLEX }\end{array}$ & 47 & $\begin{array}{l}0.21557 \\
0.64144\end{array}$ & $\begin{array}{l}0.9282 \\
0.6362\end{array}$ \\
\hline $\begin{array}{l}\text { DLR does not Granger Cause DGDP } \\
\text { DGDP does not Granger Cause DLR }\end{array}$ & 47 & $\begin{array}{l}1.28819 \\
0.44323\end{array}$ & $\begin{array}{l}0.2918 \\
0.7766\end{array}$ \\
\hline $\begin{array}{l}\text { DIT does not Granger Cause DIFN } \\
\text { DIFN does not Granger Cause DIT }\end{array}$ & 47 & $\begin{array}{l}1.50545 \\
3.36640\end{array}$ & $\begin{array}{l}0.2200 \\
0.0188\end{array}$ \\
\hline $\begin{array}{l}\text { DLEX does not Granger Cause DIFN } \\
\text { DIFN does not Granger Cause DLEX }\end{array}$ & 47 & $\begin{array}{l}2.28807 \\
1.13089\end{array}$ & $\begin{array}{l}0.0777 \\
0.3565\end{array}$ \\
\hline $\begin{array}{l}\text { DLR does not Granger Cause DIFN } \\
\text { DIFN does not Granger Cause DLR }\end{array}$ & 47 & $\begin{array}{l}0.05399 \\
0.10455\end{array}$ & $\begin{array}{l}0.9943 \\
0.9802 \\
\end{array}$ \\
\hline $\begin{array}{l}\text { DLEX does not Granger Cause DIT } \\
\text { DIT does not Granger Cause DLEX }\end{array}$ & 47 & $\begin{array}{l}0.59779 \\
2.11041\end{array}$ & $\begin{array}{l}0.6664 \\
0.0985\end{array}$ \\
\hline $\begin{array}{l}\text { DLR does not Granger Cause DIT } \\
\text { DIT does not Granger Cause DLR }\end{array}$ & 47 & $\begin{array}{l}0.16461 \\
0.59097\end{array}$ & $\begin{array}{l}0.9550 \\
0.6712 \\
\end{array}$ \\
\hline $\begin{array}{l}\text { DLR does not Granger Cause DLEX } \\
\text { DLEX does not Granger Cause DLR }\end{array}$ & 47 & $\begin{array}{l}0.95542 \\
0.47599\end{array}$ & $\begin{array}{l}0.4430 \\
0.7531 \\
\end{array}$ \\
\hline
\end{tabular}




\section{Forecast}

Fig. 20: Within-sample and out-of-sample Forecast

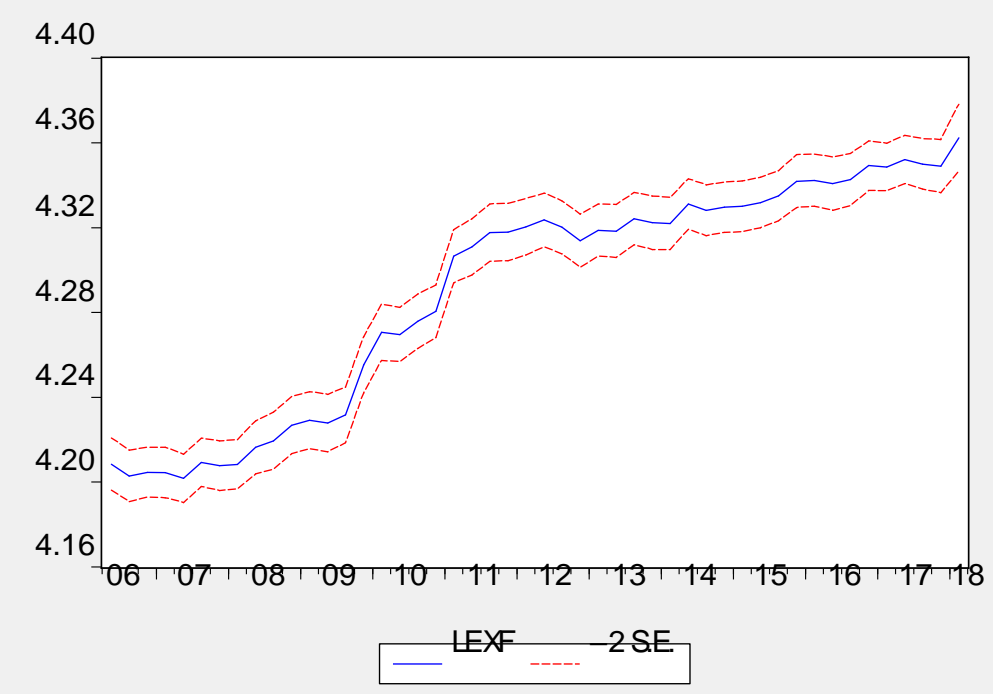

Forecast: LEXF

Actual: LEX

Forecast sample: 2005Q1 2020Q4

Adjusted sample: 2006Q2 2018Q1

Included observations: 48

Root Mean Squared Error 0.003029

Mean Absolute Error $\quad 0.002406$

Mean Abs. Percent Error 0.056089

Theil Inequality Coefficient 0.000353

Bias Proportion $\quad 0.000000$

Variance Proportion $\quad 0.000400$

Covariance Proportion 0.999595

Theil U2 Coefficient $\quad 0.374719$

Symmetric MAPE $\quad 0.056094$

—EXF_-2SE

